\title{
REDISTRIBUIÇÃO DE RENDA E CONSUMO DE ALIMENTOS NO ESTADO DE SÃO PAULO
}

\author{
MARIA CRISTINA ORTIZ FURTUOSO
}

Orientador: RODOLFO HOFFMANN

Dissertação apresentada à Escola Superior de Agricultura "Luiz de Queiroz", da Universidade de São Paulo, para obtenção do título de Mestre em Economia Agrária.

PIRACICABA

Estado de São Paulo - Brasil

1981 
a Thais

e às crianças que sofrem privaçōes de qualquer espēcie 


\section{AGRADECIMENTOS}

Aos meus pais pela educação e pelas oportunidades a mim proporcionadas.

Ao meu esposo pela compreensão e incentivo nesta jornada.

Um agradecimento especial ao Professor Rodolfo Hoffmann, que com brilhantismo e dedicação me orientou nesta pesquisa.

Aos professores Dr. Geraldo Sant'ana de Camargo Barros e Dr. Cicely M. Amaral pelas sugestões apresentadas na revisão dos originais.

Aos colegas do Departamento de Economia e Sociologia Rural pelos ensinamentos e apoio que recebi.

A Sra. Djanira Ortolan Forti, do Setor de Processamento de Dados do Departamento de Matemätica e Estatistica, e aos funcionärios do Departamento de Economia e Sociologia Rural, pela colaboração prestada.

A todos que, direta ou indiretamente, contribuiram para a realização deste trabalho. 
TND I CE

Păgina

LISTA DE TABELAS $\ldots \ldots \ldots \ldots \ldots \ldots \ldots \ldots \ldots \ldots \ldots \ldots \ldots \ldots \ldots \ldots \ldots \ldots \ldots \ldots$

LISTA DE FIGURAS $\ldots \ldots \ldots \ldots \ldots \ldots \ldots \ldots \ldots \ldots \ldots \ldots \ldots \ldots \ldots \ldots \ldots \ldots \ldots \ldots \ldots \ldots \ldots$

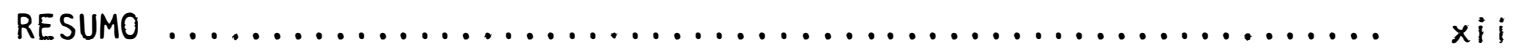

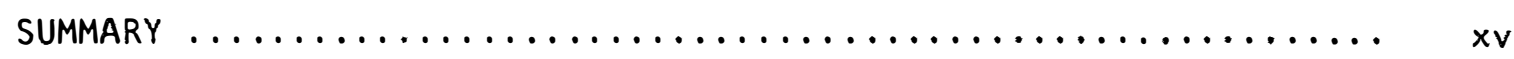

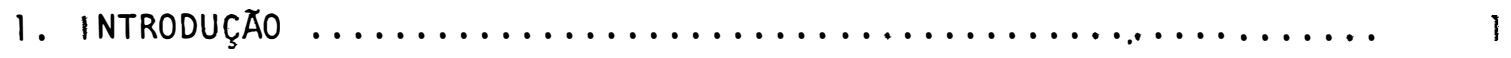

1.1. 0 Problema e sua Importância ....................

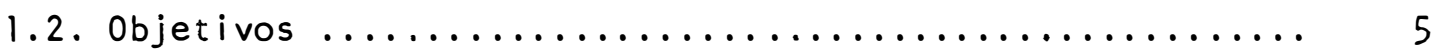

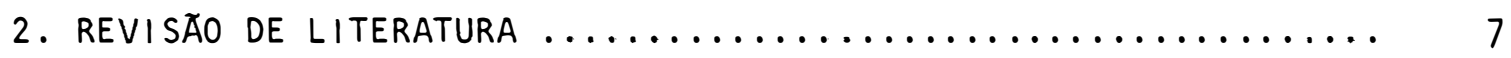

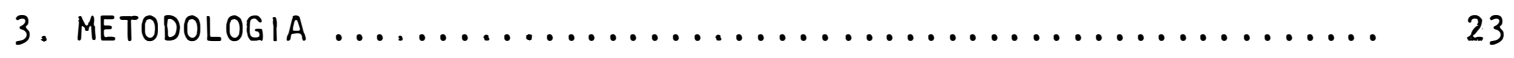

3.1. Características do Levantamento e Apresentação dos

Dados do Estudo Nacional da Despesa Familiar (ENDEF) .... 24

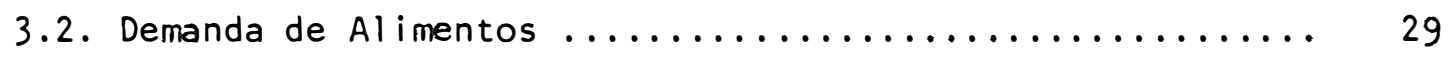

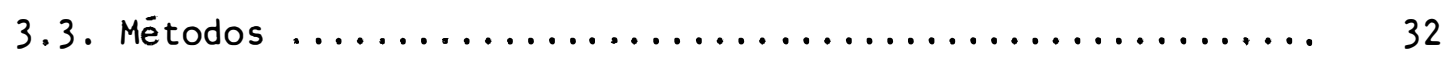

3.3.1. Coeficientes de Elasticidade .............. 32

3.3.2. Modelo de Projeção da Demanda .............. 39

4. ANALISE DOS RESULTADOS ...................... 47

4.1. Características da Distribuição de Renda no Estado

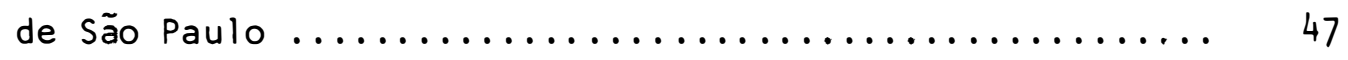

4.2. Estimativas dos Coeficientes de Elasticidade-Renda com Base na Função Log-inversa ................. 51

4.3. Estimativas dos Coeficientes de Elasticidade-Renda com Base na Poligonal ........................ 61

4.4. Projeções de Demanda ............................... 67 
Pägina

4.4.1. Distribuição do consumo pelos 3 estratos ........ 67

4.4.2. A relação entre redistribuição da renda e desigualdade do consumo entre estratos........... 75

4.4.3. Projeções do dispêndio familiar .............. 81

4.4.4. Projeções do dispêndio total ............... 89

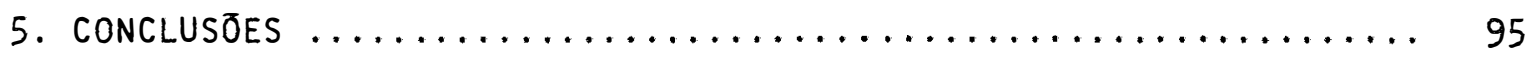

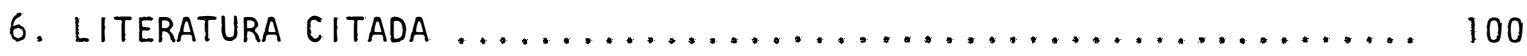

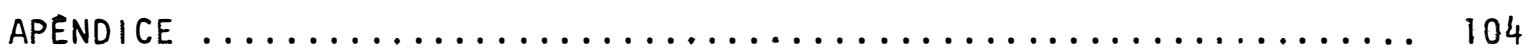




\section{LISTA DE TABELAS}

Tabela $n$ ?

1 Coeficientes de elasticidade-renda dos principais produtos, obtidos através da função bilogarítmica.

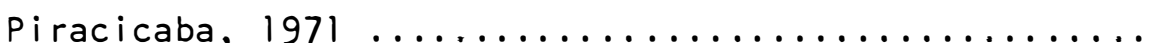

2 Coeficientes de elasticidade-renda, por grupos de alimentos, calculados através do ajustamento de poligonal bilogarítmica. Pi racicaba, 1971 ..........

3 Distrito Federal: Função renda-consumo de grandes agregados

4 Elasticidade-renda de absorção de calorias e proteinas

5 Classes de despesas para o Estado de São Paulo, àrea metropolitana de São Paulo e área urbana não-

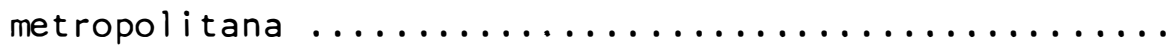

6 Classes de despesas para a área rural do Estado

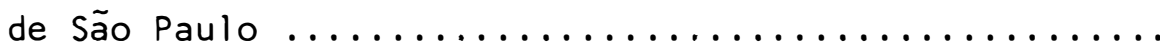

7 Estratificação da amostra segundo os Estratos de

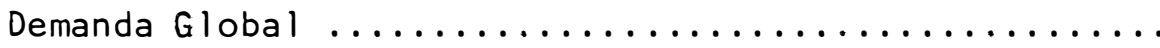

8 Taxas anuais de crescimento populacional da ärea

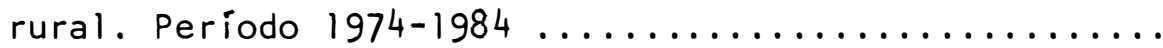

9 Taxas anuais de crescimento da renda familiar no primeiro estrato de renda para as áreas urbanas e

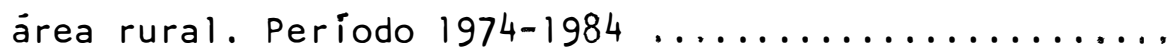


10 Indice de Gini (G) da distribuição da despesa glo bal entre familias no Estado de São Paulo, em 1974, de acordo com os dados do ENDEF. Porcentagem da população e respectiva porcentagem da des-

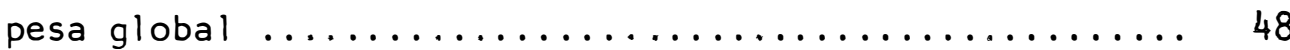

11 Coeficientes de elasticidade-renda por grupos de al imentos, nos três estratos considerados, para o Estado de São Paulo, obtidos atravēs da função

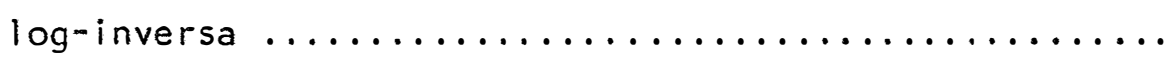

12 Coeficientes de elasticidade-renda por grupos de alimentos, nos três estratos considerados, para a ärea metropolitana, obtidos atravēs da função

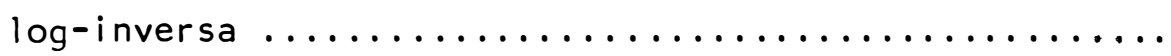

13 Coeficientes de elasticidade-renda por grupos de al imentos, nos três estratos considerados, para a ärea urbana não-metropolitana, obtidos atravēs

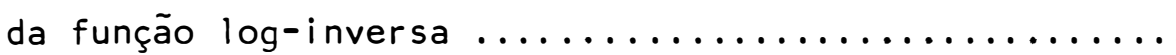

14 Coeficientes de elasticidade-renda por grupos de alimentos, nos três estratos considerados, para a ärea rural, obtidos atravēs da função log-inversa ..... 56

15 Coeficientes de regressão da função log-inversa por grupos de alimentos, para o Estado de São

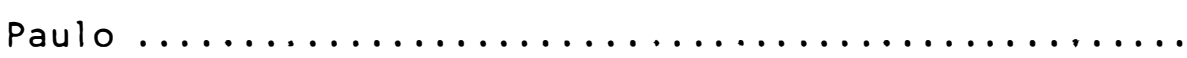

16 Coeficientes de regressão da função log-inversa por grupos de alimentos, para a área metropolita-




17 Coeficientes de regressão da função log-inverșa por grupos de alimentos, para a ärea urbana não-

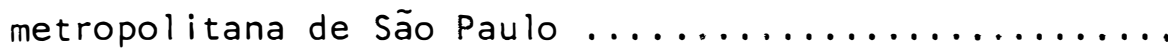

18 Coeficientes de regressão da função log-inversa por grupos de alimentos, para a ärea rural de São

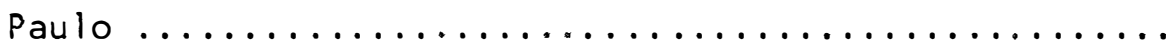

19 Coeficientes de elasticidade-renda por grupos de alimentos, nos estratos considerados, para o Estado de São Paulo, calculados através do ajustamento de poligonal bilogaritmica; coeficiente de

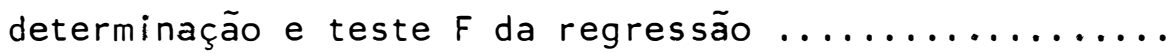

20 Coeficientes de elasticidade-renda por grupos de alimentos, nos estratos considerados, para a ärea metropolitana, calculados através do ajustamento de poligonal bilogaritmica; coeficiente de determinação e teste $F$ da regressão

21 Coeficientes de elasticidade-renda por grupos de alimentos, nos estratos considerados, para a ärea não-metropolitana, calculados através do ajustamento de poligonal bilogaritmica; coeficiente de

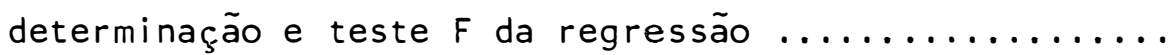

22 Coeficientes de elasticidade-renda por grupos de alimentos, nos estratos considerados, para a área rural, calculados através do ajustamento de poligonal bilogaritmica; coeficiente de determinação

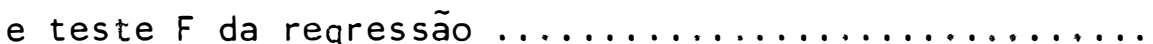


23 Participação relativa dos três grandes estratos no consumo, por grupos de alimentos, para o Estado de são Paulo ............................... 68

24 Participação relativa dos três grandes estratos no consumo, por grupos de alimentos, para a ärea

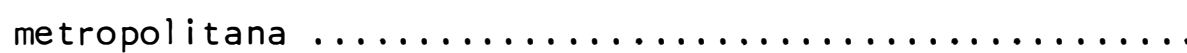

25 Participação relativa dos três grandes esţratos no consumo, por grupos dealimentos, para a ärea urbana não-metropol i tana

26 Participação relativa dos três grandes estratos no consumo, por grupos de alimentos, para a ärea

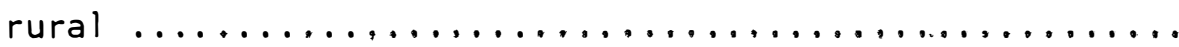

27 Indices de Gini da distribuição do consumo (G) e da renda $\left(G_{R}\right)$ entre familitias no Estado de São Pau lo, $1974-1984$

28 Dispêndio familiar anual (em milhares de cruzeiros), por gírupos de alimentos, para o Estado de São Paulo ...................................

29 Dispêndio familiar anual (em milhares de cruzeiros), por grupos de alimentos, para a ärea metropo litana $\ldots \ldots \ldots \ldots \ldots \ldots \ldots \ldots \ldots \ldots \ldots \ldots \ldots \ldots \ldots \ldots \ldots$

30 Dispêndio famitlar anual (em milhares de cruzeiros), por grupos de alimentos, para a ärea urbana

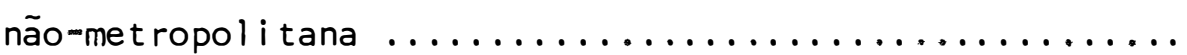


31 Dispêndio familiar anual (em milhares de cruzeiros), por gruposde alimentos, para a ärea rural ...... 86

32 Dispêndio total (em milhares de cruzeiros), por gruposde al imentos, para o Estado de são Paulo ........ 91

33 Dispêndio total (em mi lhares de cruzeiros), por gruposde alimentos, para a ärea metropolitana ........ 92

34 Dispêndio total (em milhares de cruzeiros), por grupos de alimentos, para a ärea urbana não-metro-

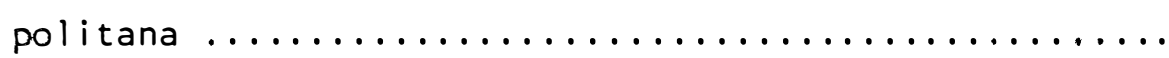

35 Dispêndio total (em milhares de cruzeiros), por gruposde alimentos, para a ärea rural .............. 94 


\section{LISTA DE FIGURAS}

Figura n?

Pägina

1 Curva de Engel para bens superiores, admitindo-se que seja uma função log-inversa ................ 34

2 Representação gräfica de uma poligonal (temos $\operatorname{tg} \theta=b ; \operatorname{tg} \phi=b+c ; \operatorname{tg} \psi=b+c+d) \ldots \ldots \ldots 38$

3 Curvas de Lorenz da distribuição da despesa global entre familias no Estado de São Paulo, em 1974

4 Relação entre os indices de desigualdade da distribuição do consumo e da renda no Estado de São Paulo - 1984 


\title{
REDISTRIBUIÇÃO DE RENDA E CONSUMO DE ALIMENTOS \\ NO ESTADO DE SAOO PAULO
}

\author{
Maria Cristina Ortiz Furtuoso \\ Orientador: Rodolfo Hoffmann
}

\section{RESUMO}

0 objetivo geral deste trabalho foi a determinação e anälise do efeito da redistribuição de renda disponivel sobre a demanda de alimentos no Estado de São Paulo.

Foram utilizados dados referentes às despesas globais anuais por familia com diversos grupos de alimentos, obtidos através de Estudo Na cional da Despesa Familiar - ENDEF. Este estudo foi realizado no período de agosto de 1974 a agosto de 1975, englobando 4.168 domicílios. Os dados foram agrupados em três grandes classes ou estratos para as äreas urbanas e ärea rural.

A metodologia seguida apresentou duas etapas. A primeira consistiu na obtenção de elasticidades-renda da demanda dos alimentos para os diferentes grupos de renda, coeficientes estes calculados com base em dois tipos de relação funcional: log-inversa e poligonal.

Na segunda etapa procedeu-se à obtenção de projeções de demanda dos produtos alimentícios com hipóteses alternativas de redistribuição de renda. 
Na primeira hipōtese admitiu-se que a distribuição de renda se mantivesse constante durante o período de projeção 1974-1984, considerando-se a mesma taxa de crescimento da renda familiar (3,5\%) tanto para os três grandes estratos como para as áreas urbanas e rural.

Na segunda hipōtese simulou-se uma redistribuição de renda moderada em favor das classes baixa e média, adotando-se as seguintes taxas de crescimento da renda familiar: $3,5 \%$ para a média da população, $2 \%$ para o terceiro estrato e $4 \%$ para o segundo estrato. Admitiu-se as mesmas taxas para as quatro áreas de estudo. Fixadas as taxas de crescimento da renda global e dos dois estratos superiores, determinou-se a taxa de crescimento da renda do primeiro estrato por diferença.

Para o Estado de São Paulo como um todo admitiu-se ainda uma terceira hipōtese relativa à distribuição de renda, um pouco mais drás tica. As taxas de crescimento da renda familiar adotadas foram: 3,5\% para a média da população, $0 \%$ para o terceiro estrato e $4 \%$ para o segundo estrato, obtendo-se a taxa para o primeiro estrato, novamente, por diferença.

Em relação à população admitiu-se taxas anuais de crescimen to especificas para cada uma das áreas em estudo: 3,4\% para o Estado de São Paulo, 5,5\% para a área metropolitana e 4,28\% para a área urbana nãometropolitana. Fixadas tais taxas de crescimento populacional, pode-se deduzir a taxa relativa à ärea rural.

Ressalte-se que o modelo matemático utilizado considerou ex pressamente como variáveis determinantes da demanda a população, o nível de renda e sua distribuição. Supôs-se uma composição etária da população e uma estrutura de preços relativos constantes. 
Os resultados da pesquisa confirmaram a influência decisiva do padrão de distribuição de renda sobre a estrutura de consumo de alimentos, diferenciando-a segundo os diferentes níveis de renda. Assim, a meIhoria do quadro alimentar da população de baixa renda está diretamente re lacionada com alterações na estrutura de distribuição de renda. Note-se que, no Estado de São Paulo, o dispêndio alimentar do estrato superior $\left(E_{3}\right)$ que era 2,24 vezes o do estrato inferior $\left(E_{1}\right)$, com a alternativa de redistribuição drástica passa a ser apenas 1,37 vezes maior. 0 índice de Gini da distribuição do consumo decresce, neste período, de 0,18 em 1974 para 0,07 em 1984 .

De um modo geral, os maiores aumentos no consumo ocorrem para os grupos de alimentos que apresentam elasticidade-renda elevada. Entre estes, podemos destacar as "Frutas" cujo dispêndio do estrato superior, que no ano-base se apresentava 4,78 vezes o do estrato inferior, em 1984, no caso de uma redistribuição drástica, passa a ser apenas 1,82 vezes maior. 0 indice de Gini do consumo que era igual a 0,34 em 1974 passa a 0,13 em 1984 . 
REDISTRIBUTION OF THE INCOME AND THE DEMAND FOR FOOD In THE STATE OF SÃO PAULO

Maria Cristina Ortiz Furtuoso

Adviser: Rodolfo Hoffmann

\section{SUMMARY}

The general objective of this study was to determine the effect of the re-distribution of the available income on the demand for food in the State of São Paulo.

Data relating to total annual expenditures per family on several groups of food products obtained through the National Study of Family Expenditures (ENDEF) were utilized. This study was carried out during the period August 1974 to August 1975, and included 4168 homes. The data were grouped into three large classes or strata for the urban areas and rural area.

The methodology utilized presented two phases. The first consisted of obtaining income elasticities of the demand for food for the different income groups. These coefficients were calculated based on two types of functional relationships: reverse-log and polygonal.

In the second phase projections of the demand for food products were obtained with alternative hypotheses of income re-distribution. 
In the first hypothesis it was admitted that the income distribution was held constant during the projection period 1974-84, considering the same rate of growth of family income $(3.5 \%)$ for the three large strata as well as for the urban and rural areas.

In the second hypothesis, a moderate income re-distribution in favor of the low and middle classes was simulated, by adopting the following rates of income growth: $3.5 \%$ for the population average, $2 \%$ for the third stratum and $4 \%$ for the second stratum. The same rates were admitted for the four areas under study. After fixing the rates of growth of total income and the two higher strata, the rate of growth of income for the first stratum was determined by deducting one from the other.

A third hypothesis, slightly more drastic, relating to income re-distribution was admitted for the State of São Paulo. The adopted rates of growth of family income were $3.5 \%$ for the population average, $0 \%$ for the third stratum and $4 \%$ for the second stratum, the rate for the first stratum once again being obtained by deducting one from the other.

With reference to the population, specific annual growth rates were admitted for each of the areas under study: $3.4 \%$ for the State of São Paulo, 5.5\% for the for the metropolitan area, and $4.28 \%$ for the non-metropolitan urban area. After fixing these rates of population growth, the rate relating to the rural area may be deducted.

The mathematical model utilized considered expressly as demand determining variables: the population, the level and distribution 
of income, and its distribution. A population age composition and a structure of constant relative prices were supposed.

The results of the research confirmed the influence of the income distribution pattern on the food consumption structure, differentiating it according to the different income levels. Thus, the improvement of the food consumption picture of the low income population is directly related to changes in the income distribution structure. It should be noted that in the State of São Paulo, food expenditures of the highest stratum $\left(E_{3}\right)$ which was 2.24 times that of the lowest stratum $\left(E_{1}\right)$, becomes only 1.37 timeshigher with the drastic re-distribution alternative. Gini's index of consumption distribution declines in this period, from 0.18 in 1974 to 0.02 in 1984 .

In general, the largest increases in consumption occur for food groups which present high income elasticity. Among these, "fruits" are outstanding, as the expenditure of the highest stratum in the base-year was 4.78 times that of the lowest stratum and in 1984, in the case of a drastic re-distribution, becomes only 1.82 times higher. Gini's index of consumption which was equal to 0.34 in 1974 becomes 0.13 in 1984. 
1. INTRODUÇAO

1.1. O. Problema e sua importāncia.

Na sociedade contemporânea a meta prioritária dos diversos países tem sido o desenvolvimento econômico. Um dos principais fatores para a manutenção e elevação do ritmo de desenvolvimento de uma nação se localiza na alimentação adequada de sua população, que vem sendo continuamente considerada como um agente de desenvolvimento por propiciar condições de se quebrar o círculo vicioso má nutrição-baixa produtividade-po breza. Isto porque, a deficiência alimentar da população age diretamente sobre a produtividade do trabalho humano, refletindo negativamente sobre toda a economia.

Basicamente, a mä nutrição pode ser causada por fatores re lacionados com oferta e demanda, os quais contribuem para uma ingestão dos nutrientes aquém dos requerimentos minimos, como também devido a problemas de absorção dos nutrientes ingeridos. O presente trabalho relaciona-se com o primeiro fator, o qual tem sido objeto constante das pesquisas em ciências sociais, enquanto os pesquisadores da área biomédica tem se preocupado mais frequentemente com o segundo fator. 
Numerosos estudos têm evidenciado a influência da renda no consumo alimentar. A simples anälise do consumo em termos dos dados médios nacionais para muitos países em desenvolvimento mostra pouca ou nenhuma deficiência nutricional. Porēm, quando tais dados são desagregados por grupos de renda, värias deficiências são frequentemente observadas.

Especificamente para o Brasil, foi detectada a existência em maior grau da subnutrição nos grupos populacionais de baixa renda em todas as regiões brasileiras, principalmente nas äreas perifēricas das grandes cidades e no meio rural (Silva, 1970).

Assim, verifica-se que nestes países o problema de deficiências nutricionais é mais um problema de distribuição desigual dos nutrientes disponiveis do que de escassez propriamente dita-'.

Entre as medidas sugeridas pelos estudiosos para uma meIhor adequação nutricional estā a redistribuição de renda, visando a elevação da renda da população de baixo poder aquisitivo.

0 problema da distribuição de renda tem sido objeto de estudos de muitos economistas através do tempo. Entre os teóricos que se preocuparam com a relação entre demanda e distribuição de renda podemos destacar:

Cournot 2 ' em 1838, jā afirmava que a demanda de um dado produto, além de ser uma função do seu preço, dependia essencialmente do tamanho da população, da renda média e de sua distribuição.

\footnotetext{
I/ Ver SCHUH e ALVES (1970).

2I Ver DIAS (1976).
} 
Em 1913, Lenoir $2 /$ estabeleceu e determinou a curva da demanda de mercado, afirmando que esta dependia não só das demandas individuais mas também da maneira como a renda total é distribuída entreesses individuos.

Pareto (1949), em seu "Corso di Economia Politica", também assinalou a existência de relação entre demanda e distribuição de ren da. Para ele, a distribuição de renda era um dos principais fatores que deveriam ser levados em conta para se conhecer as leis que regem a oferta e a demanda.

Embora a dependência entre demanda e distribuição de renda tenha sido evidenciada por värios expoentes da histöria do pensamento eco nômico, nem sempre esta relação tem sido considerada nos estudos de demanda.

Recentemente, em reunião realizada pela FAO em 1969, no Chile, da qual participaram värias delegações da América Latina, com o objetivo de discutir o Estudo Regional Provisional do Plano Indicativo Mundial ( $P \mid M)$ para a América do Sul, foram levantadas dúvidas sobre as projeções de demanda deste örgão. Värias delegações declararam que essas projeções eram baixas e pouco realistas, por não considerar em seus cálculos os possíveis efeitos de variações na distribuição de renda sobre a demanda.

Este trabalho propõe-se a examinar a influência da distribuição de renda sobre a aquisição de alimentos. 
0 estudo do efeito da redistribuição de renda sobre o perfil da demanda de alimentos sobressai como trabalho de significativa importância, principalmente em países onde a subnutrição compromete o seu desenvolvimento, jā que ē possível utilizar o mecanismo de redistribuição de renda com o objetivo de se atingir um maior progresso social e econômico.

0 desenvolvimento, crescimento econômico e urbanização ten dem a alterar o padrão de distribuição de renda existente $3 /$. Se essa alteração se der no sentido de uma distribuição de renda mais igualitäria, ocorrendo aumentos porcentuais mais elevados para as camadas sociais de baixa renda, pode ocasionar aumentos sensiveis na demanda de alimentos, exigindo alterações na estrutura produtiva existente.

A quantificação do impacto da redistribuição de renda sobre a demanda è de inegävel utilidade, pois seu conhecimento pode auxiliar os örgãos de planejamento da administração püblica, na orientação de politicas econômicas, tais como: importações de alimentos conforme a ofer ta futura esperada, alterações na produção de alimentos paralelamente às evoluções observadas no perfil de demanda, adequando a produção ao consumo, evitando elevações nos preços dos produtos.

A presente anālise pode também ser de interesse por fornecer subsídios que permitem sugestões de politica nutricional.

3/ KUZNETS (1955)

Idem (1963)

Idem (1966) 


\subsection{Objetivos}

Supondo constantes a composição etäria e a.estrutura de pre ços relativos para todos os produtos, o presente trabalho tem como objetivo geral apresentar um quadro analítico do efeito da redistribuição de ren da disponível sobre o consumo alimentar, aprofundando a anälise econômica da estrutura da demanda de alimentos. Não serä analisado neste trabaiho - impacto desta redistribuição de renda sobre a demanda de outros produtos. O fato de se pressupor que os preços relativos șão constantes implica em admitir que a quantidade ofertada, a esses preços, acompanha as variações da demanda devidas à redistribuição de renda, ou seja, implica em admitir que a oferta ë perfeitamente elästica (para todos os bens).

Os objetivos especificos são:

a) Estimar os coeficientes de elasticidade-renda da demanda de alimentos para diversos estratos de renda, verificando se as diferenças dos coeficientes entre estratos são estatisticamente significativas.

b) Em função de restrições formuladas, obter projeções de demanda, para produtos selecionados, para o periodo 1974-1984.

c) Com base nos resultados obtidos, fornecer subsídios para decisões econômicas relacionados à demanda de alimentos.

A previsão de que uma redistribuição de renda afeta a quantidade e o padrão de consumo de alimentos se baseia nas seguintes hipöteses, jä evidenciadas por värios trabalhos anteriores $\stackrel{4 /}{=}$

4/ Ver PEREZ (1973) e MINISTERIO DA AGRICULTURA (1967). 
a) A elasticidade-renda da demanda de al imentos diminui à medida que cresce a renda.

b) O valor da elasticidade-renda de alimentos e a sua diminuição com o aumento da renda são diferentes para diferentes produtos. 


\section{REVISATO DE LITERATURA}

Existe um grande nümero de estudos sobre demanda de alimentos. Grande parte destes não consideram explicitamente os vínculos existentes entre o consumo e a distribuição de renda.

Nesta revisão bibliogräfica serä elaborada uma retrospect va dos trabalhos sobre demanda que mais se relacionem com os objetivos propostos pelo presente trabalho.

Trabalhando com dados da F.G.V., O MINISTERIO DA AGRICULTURA (1967) procedeu a uma pesquisa sobre orçamentos familiares, estimando as relações funcionais entre renda e consumo de alimentos para a população urbana do Estado da Guanabara. A amostra foi estratificada em nove grupos de renda.

Quanto ao aspecto da distribuição de renda, foi dada ênfase somente à determinação desta distribuição, não tendo sido feita nenhuma tentativa de averiguação da influência de sua variação na estrutura de consumo da população. 
Estimaram-se os coeficientes de elasticidade-renda da procura de alimentos, segundo os níveis médios de renda anual per capita para 12 categorias de alimentos.

A composição do consumo alimentar entre as diferentes clas ses de renda mostrou-se bastante diferenciada, principalmente no que tange aos alimentos como ovos, leite, queijo e frutas. Os valores mais altos para as elasticidades-renda médias (acima de 0,8 ) foram os obtidos para a carne, leite, ovos, queijo e óleos de origem vegetal. Os itens fu bá e farinha de mandioca apresentaram elasticidades-renda decrescentes.

ARAOJO (1970) efetuou pesquisa na cidade de Vitória, capital do Espírito Santo, abrangendo cem famílias entrevistadas pertencentes a diversas classes de renda.

Um dos objetivos principais era o de estimar o comportamen to do consumidor frente a diferentes níveis de renda e educação. Determinou-se as proporções de renda gasta em alimentação quando ocorrem elevações nos níveis de renda. Para tal, foi calculada a elasticidade-renda através dos pontos médios dos vários intervalos de renda, para um grupo de 15 al imentos.

0 autor também determinou as funções gasto-renda e consumo-renda, cujos resultados estatísticos mostraram uma relação crescente para quase todas as categorias de alimentos selecionados. Em relação ao fator educação, o autor chega à conclusão, que pelo menos neste estudo, esta variável não explica o comportamento do consumo de produtos alimentí cios, pois os resultados não apresentaram diferenças significativas nos dispêndios alimentares entre as diferentes classes de educação. 
CASTRO (1972), procurando determinar os vínculos existentes entre a estrutura da demanda de alimentos e a evolução do processo de comercialização agrícola no Brasil, trabalhou com dados de orçamentos familiares da ärea de Piracicaba, abrangendo 236 famílias da ärea urbana. Os coeficientes de elasticidade-renda foram obtidos atravēs da função bilogarítmica, cujos resultados permitiram a caracterização das alterações na demanda quando hä expansão da renda familiar.

Constatou-se a existência de um mercado consumidor extrema mente heterogêneo entre as diferentes camadas da população, fator que in flui decisivamente na evolução do sistema de comercialização.

Enquanto nos estratos de renda elevada a alimentação é rica e variada, com grande nümerode produtos industrializados, nos estratos inferiores ela se apresenta com reduzido número de produtos, a maioria de natureza calörica.

Em relação ao fator renda, notou-se que à medida que ocorrem elevações na renda, o dispêndio em alimentos cresce proporcionalmente mais nas classes de renda inferior. No entanto, o consumo de verduras, frutas, legumes e carnes, ou seja, produtos com elasticidade-renda elevada, apresentam uma tendência de crescimento mais rápida do que a de cereais. Alguns dos resultados encontram-se na Tabela 1.

Em vista dos resultados espera-se que mudanças na estrutura de consumo, em função do crescimento da renda, devam ser diferentes para as diferentes faixas da população, implicando em alterações na importância relativa dos setores de produção. Daí a importância da anālise da estrutura de consumo, principalmente em países em processo de desenvolvimen to, ajudando a prever ou evitar possíveis desequilíbrios entre produção e consumo. 
Tabela 1. Coeficientes de elasticidade-renda dos principais produtos, ob tidos atravēs da função bilogarítmica. Piracicaba, 1971

\begin{tabular}{lc}
\hline Produtos & $\begin{array}{c}\text { Coeficientes de } \\
\text { Elasticidade }\end{array}$ \\
\hline Leite ( itro) & 0,9810 \\
Ovos (dz) & 0,7708 \\
Arroz (kg) & $-0,1400$ \\
Feijão (kg) & $-0,3122$ \\
Farinha de milho (kg) & $-0,0676$ \\
Batata (kg) & 0,2271 \\
Açücar cristal (kg) & $-0,2140$ \\
Açücar refinado (kg) & 1,4838 \\
Tomate (kg) & 0,6906 \\
Cenoura (kg) & 0,7920 \\
Carne bovina de la (kg) & 0,7757 \\
Frango (kg) & 1,2380 \\
\hline
\end{tabular}

Fonte: CASTRO (1972)

PEREZ (1973) realizou pesquisa sobre orçamentos familiares na cidade de Piracicaba. A ênfase do estudo foi para a relação existente entre consumo e renda a nivel familiar.

Foram estimados três tipos de coeficientes de elasticidade: a elasticidade-renda, a elasticidade dispêndio-renda e a elasticidade dispêndio-dispêndio total. A amostra consistiu em 255 familias 
pertencentes a diversas classes de renda, as quais foram estratificadas em três níveis, referentes à renda mensal per capita.

A pesquisa considera 131 tipos de alimentos agrupados em 19 categorias. Foram testados para os cälculos das elasticidades as seguintes funções: a) linear, b) bilogarítmica, c) log-inversa, d) semi-logaritmica. A variävel dependente foi o consumo per capita de uma da da categoria de alimento e a independente a renda per capita ou dispêndio total per capita. A função bilogaritmica foi a utilizada para representar o consumo de produtos frente ao crescimento da renda, consistindo no ajustamento de uma poligonal aos dados. O objetivo desse ajuste foi obter coeficientes de elasticidade variàveis segundo as diferentes classes de renda ou dispêndio mensal per capita. Esse modelo, tambëm, possibilita que seja feito o teste estatistico das diferenças de elasticidade entre os diferentes estratos de renda.

0 método da poligonal apresentou bons resultados para as elasticidades dispêndio-renda e dispêndio dispêndio-total, não sendo muito satisfatörios os obtidos para as elasticidades-renda cujos coeficientes de determinação aparecem com valores muito baixos (ver Tabela 2). 
Tabela 2. Coeficientes de elasticidade-renda, por grupos de alimentos, calculados através do ajustamento de poligonal bilogarítmica. Piracicaba, 1971

\begin{tabular}{|c|c|c|c|c|c|}
\hline \multirow{2}{*}{$\begin{array}{l}\text { Grupos de } \\
\text { Alimentos }\end{array}$} & \multicolumn{3}{|c|}{ Coeficiente de elasticidade } & \multirow{2}{*}{$r^{2}$} & \multirow[b]{2}{*}{ Teste $F$} \\
\hline & $\begin{array}{c}\text { até } \\
\operatorname{cr} \$ 100,00\end{array}$ & $\begin{array}{l}\text { mais de } \operatorname{Cr} \$ 100,00 \\
\text { a } \operatorname{Cr} \$ 250,00\end{array}$ & $\begin{array}{l}\operatorname{mais} \text { de } \\
C r \$ 250,00\end{array}$ & & \\
\hline Leite & 1,12 & 1,57 & 0,58 & 0,07 & $6,7 * \star$ \\
\hline Ovos & 0,92 & 1,36 & 0,15 & 0,09 & $8,3 * *$ \\
\hline Arroz & 0,06 & $-0,31$ & $-0,34$ & 0,04 & $3,9 *$ \\
\hline Feijão & $0,71^{\star}$ & $-0,50$ & $-1,22$ & 0,15 & $15,3 * *$ \\
\hline Farinha de milho & 0,71 & $-0,64$ & $-0,03$ & 0,01 & 0,6 \\
\hline Batata & 0,70 & $-0,25$ & 0,39 & 0,01 & 1,2 \\
\hline Pão & $1,84 *$ & 0,34 & 0,06 & 0,06 & $5,6 * \star$ \\
\hline Café & 0,44 & 0,10 & 0,03 & 0,01 & 0,7 \\
\hline Alface & 1,80 & $-0,41$ & 2,01 & 0,04 & $3,4 *$ \\
\hline Açücar cristal & 0,27 & 0,09 & $-1,64$ & 0,05 & $4,4 * \star$ \\
\hline Açücar refinado & $2,82 \star \star$ & 3,06 & 0,28 & 0,25 & $28,2 * \star$ \\
\hline Laranja & $5,01 * \star$ & $-0,95^{\star \star}$ & 0,79 & 0,13 & $12,4 * *$ \\
\hline Banana & 1,32 & 0,53 & 0,41 & 0,03 & 2,6 \\
\hline Tomate & $2,21 * \star$ & $0,29 *$ & 0,45 & 0,12 & $11,1^{\star \star}$ \\
\hline Cenoura & 0,57 & 0,95 & 2,15 & 0,16 & $15,9 * *$ \\
\hline 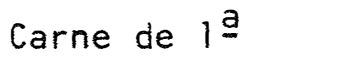 & $1,43 * *$ & 0,55 & 0,91 & 0,14 & $13,2^{\star \star}$ \\
\hline Frango & $3,24 * \star$ & 1,90 & 0,16 & 0,24 & $26,1 \star \star$ \\
\hline
\end{tabular}

* Significativo ao nivel de $5 \%$

** idem ao nivel de $1 \%$

Fonte: PEREZ (1973). 
MELLOR (1967) aponta dois fatores principais como responsáveis pela alteração na procura de alimentos: expansão demográfica e crescimento da renda per capita.

Para Mellor, a influência isolada desses fatores è notada de modo diferencial, sendo que a taxa de crescimento populacional afeta to dos os produtos em quantidades proporcionalmente iguais, enquanto que a va riação da renda causa um impacto não uniforme para os värios grupos de pro dutos.

Por outro lado, tambëm observa-se diferenças substanciais nas elasticidades-renda, de acordo com os grupos sociais e tipos de produto. Nos paises que apresentam um grau de desenvolvimento mais elevado, a elasticidade para cereais tende a ser menor. Notamos também a diferença no valor das elasticidades entre os cereais e produtos como a carne e o leite.

Ressalta, ainda, que em certos estägios de desenvolvimento, a influência da renda sobre a procura de alimentos pode predominar sobre - efeito do crescimento populacional. Somente em países com alta renda per capita a variação da renda apresenta influência insignificante sobre a demanda de alimentos.

Em países em desenvolvimento, além da elasticidade-renda de alimentos ser mais elevada, uma porcentagem maior da renda é destinada à aquisição de alimentos, o que conjuntamente apresenta um efeito extremamen te forte sobre a demanda de alimentos, fazendo com que aumentos na renda per capita resultem em grandes aumentos na demanda de gêneros alimenticios. 
Em vista disso, o autor afirma que a estrutura distributiva da renda è de grande importância na determinação da procura de alimentos, pois quando alterada, toda a estrutura de demanda será modificada .

CODEPLAN (1970), visando obter projeções de demanda de pro dutos alimenticios até 1975 para o Distrito Federal, no sentido de fornecer subsidios para a política de abastecimento, efetuou um levantamento de dados no setor urbano, limitando-se aos produtos de maior peso no orçamento familiar 5 .

$\mathrm{Na}$ análise do comportamento do consumo frente a variações na renda foram ajustadas funções renda-consumo e calculadas as elasticidades-renda, utilizando-se dados de "renda líquida" e do consumo físico para os produtos isolados e não o valor monetärio, evitando possiveis dis torções causadas por variações nos preços dos produtos $6 /$. Para os grandes agregados consideraram-se os gastos monetärios.

Foi adotada a função:

$$
y_{t}=A \cdot x_{t}^{b}
$$

onde:

$$
\begin{aligned}
& y_{t} \text { è o consumo no tempo } t \text {. } \\
& x_{t} \text { è a renda no tempo } t \text {. } \\
& A \text { e b são os parâmetros. }
\end{aligned}
$$

5/ 0 ano considerado foi 1968.

6/ A renda liquida é definida em termos da renda bruta menos os valores da contribuição previdenciária e o pagamento do imposto de renda. 
Os resultados obtidos mostraram-se satisfatórios, apresentando parâmetros significativos ao nivel de $1 \%$ e coeficientes de determinação $\left(r^{2}\right)$ elevados. Alguns resultados obtidos aparecem na Tabela 3. Novamente, observa-se elasticidades-renda mais elevadas para os alimentos proteicos e hortícolas.

Tabela 3. Distrito Federal: Função renda-consumo de grandes agregados

\begin{tabular}{llcr}
\hline Despesas & Função Ajustada & $\begin{array}{c}\text { Elasticidade- } \\
\text { renda }\end{array}$ & $r^{2}$ \\
\hline Alimentação em casa & $\hat{Y}=12,65 \cdot x^{0,52}$ & 0,52 & 0,967 \\
Gastos totais com alimentação & $\hat{Y}=8,40 \cdot x^{0,59}$ & 0,59 & 0,984 \\
Amiläceos & $\hat{Y}=28,31 \cdot x^{0,21}$ & 0,21 & 0,919 \\
Gorduras e öleos & $\hat{Y}=3,52 \cdot x^{0,30}$ & 0,30 & 0,942 \\
Carnes e peixes & $\hat{Y}=1,49 \cdot x^{0,62}$ & 0,62 & 0,938 \\
Laticinios e ovos & $\hat{Y}=0,70 \cdot x^{0,63}$ & 0,63 & 0,969 \\
Verduras e frutas & $\hat{Y}=0,67 \cdot x^{0,71}$ & 0,71 & 0,957 \\
\hline
\end{tabular}

Fonte: CODEPLAN (1970).

Nas projeções de demanda de alimentos foram consideradas como variäveis explícitas do modelo as taxas de crescimento da população, taxas de crescimento da renda real (3\% a.a.) e a elasticidade-renda dos produtos, expressando a relação de acordo com a seguinte equação:

$$
c_{i, t}=\alpha \cdot c_{i, t-1}
$$


onde:

$$
\begin{aligned}
& \alpha=\left[\left(\varepsilon_{i} r y h_{t}\right)+1\right]\left[1+r N_{t}\right] \text { sendo que, } \\
& c_{i, t} \text { é o consumo global do produto } \underline{i} \text {, no periodo } \underline{t} \text {. } \\
& c_{i, t-1} \text { é o consumo global do produto } \underline{i} \text {, no período } \underline{t-1} \text {. } \\
& \varepsilon_{i} \text { é a elasticidade-renda do produto } \underline{i} \text {. } \\
& r y h_{t} \text { é a taxa de crescimento da renda per capita. } \\
& r N_{t} \text { é a taxa de crescimento da população no ano } \underline{t} .
\end{aligned}
$$

Deve ser salientado que na estimativa das demandas futuras não foi levada em consideração a distribuição da população em estratos de renda. No cälculo das elasticidades-renda foi usada a função bilogarítmi ca, a qual apresenta uma elasticidade constante para todos os niveis de renda, o que reflete, de certo modo, uma situação irreal. Como consequên cia, os resultados foram sensivelmente prejudicados, tendo em vista o fato de que o consumo tem apresentado uma evolução totalmente diferenciada, tanto em qualidade como em quantidade, para os diferentes estratos sōcioeconômicos. Existem numerosos estudos que evidenciam este fato, entre eles podemos destacar Pinstrup e Caicedo, 1978.

Estudo da FAO (1972), preparado por M.de Nigris, levou a cabo uma pesquisa sobre demanda de alimentos, abrangendo 11 países da Amé rica Latina, inclusive o Brasil. Estimaram o efeito da redistribuição de renda sobre projeções para 1980, da demanda, dos principais al imentos que compõem a dieta em cada país, visando obter projeções mais realistas de consumo . 
A população de cada país foi dividida em quatro grupos de renda: mínima, média, al ta e máxima, contendo respectivamente $50 \%, 30 \%$, $15 \%$ e $5 \%$ da população. Foram levantadas duas hipóteses de redistribuição de renda, uma moderada e outra drástica, calculando a demanda per capita para cada grupo de renda e para os diversos produtos constituintes das diferentes dietas.

Os resultados obtidos por este trabalho evidenciam a influência da distribuição da renda sobre o consumo, indicando um aumento na demanda de produtos agricolas da ordem de $9-9,5 \%$ com a redistribuição moderada da renda e de $13-14 \%$ com a drástica.

Especificamente para o Brasil, foi detectada escassez de calorias para os $50 \%$ mais pobres da população. O estudo mostra que essa deficiência não seria sanada até 1980 a não ser que houvesse uma alteração na distribuição da renda favorecendo a população carente.

ATEAGA e MARTINEZ (1973) realizaram um estudo com o objetivo de analisar o efeito da redistribuição de renda disponivel sobre a demanda de alimentos no Chile.

Os autores construíram um modelo simulando situações alternativas de redistribuição de renda, fazendo projeções da demanda de produtos agropecuários para o periodo 1970-1980.

A metodologia consistiu em considerar a renda disponivel e sua distribuição como fatores influentes sobre a demanda, dividindo a população em três grupos de renda: baixa, média e alta com 50\%, $30 \%$ e $20 \%$ da população respectivamente. No cálculo das projeções, três hipóteses 
foram feitas sobre a redistribuição de renda pessoal: nula, moderada e drästica. O país foi subdividido em regiões econômicas, considerando que estas apresentariam diferenças tanto no que se refere às elasticidadesrenda como no que se refere aos niveis de renda e sua distribuição.

Inicialmente, foram calculadas as respectivas elasticidades-renda em cada região. Admitindo que a relação entre consumo e renda seja a log-inversa pode-se determinar a elasticidade-renda em cada estrato de renda, utilizando a seguinte expressão:

$$
n_{\text {rgt }}=\bar{n}_{0} \cdot \bar{Y}_{0} / Y_{\text {rgt }}
$$

onde:

$$
\begin{aligned}
& \eta_{r g t} \text { é a elasticidade-renda do grupo } \underline{g} \text {, da região } \underline{r} \text {, no ano } \underline{t} \text {, } \\
& Y_{\text {rgt }} \text { é a renda média per capita do grupo } \underline{g} \text {, da região } \underline{r} \text {, no ano } \underline{t} \text {, e } \\
& \bar{\eta}_{0} \text { é a elasticidade-renda média da demanda correspondente a um ni- } \\
& \quad \text { vel de renda } \bar{Y}_{0} .
\end{aligned}
$$

Em seguida, utilizando as elasticidades-renda obtidas foram estimadas as quantidades demandadas de alimentos, considerando o efeito da redistribuição de renda. Adotou-se para tal, um modelo de projeção de demanda, representado pela relação:

$$
D_{T}=\sum_{r=1}^{R} \sum_{g=1}^{G} P_{\text {rgo }} C_{\text {rgo }} \prod_{t=1}^{T}\left(1+\Delta P_{r g t} / P_{r g t-1}\right)\left(1+n_{r g t} \cdot \Delta Y_{r g t} / Y_{r g t-1}\right)
$$

onde:

$D_{T} \ddot{e}$ a demanda total do país,

$P_{\text {rgo }} \vec{e}$ a população do ano base,

$C_{\text {rgo }} \ddot{e}$ o consumo do ano base, 
$\Delta P_{\text {rgt }} / P_{\text {rgt-l }}$ ë a taxa média de crescimento anual da população do grü po $\underline{g}$, da região $\underline{r}$, e

$\Delta_{\text {rgt }} / Y_{\text {rgt-l }}$ é a taxa média de crescimento anual da renda disponível per capita do grupo de renda $\underline{g}$, da região $\underline{r}$.

Entre as värias conclusões do estudo, comprovou-se que po liticas redistributivas de renda em favor das classes de renda mais baixa aumentam consideravelmente a demanda de alimentos, refletindo substan cialmente nos alimentos com alta elasticidade-renda como a carne, o leite e as frutas.

A metodologia apresentada por estes autores foi utilizada para o desenvolvimento do presente estudo.

PINSTRUP e CAICEDO (1978) realizaram trabalho pioneiro na ărea, objetivando uma contribuição para a orientação de políticas redistributivas de renda, que visem a eliminação ou redução da mä nutrição.

Efetuaram uma pesquisa com a população de Cali, Colômbia, onde quantificaram a relação entre redistribuição de renda e a absorção de determinados nutrientes. A amostra consistiu em 230 familias estrati ficadas em cinco níveis de renda.

Usando uma análise comparativa foi avaliado o efeito da redistribuição de renda sobre a absorção calörica e protéica, baseado em duas pressuposições sobre a oferta de alimentos: uma, com oferta fixa,na qual a elasticidade-oferta é zero e a outra, com uma oferta ilimitada a preços correntes (oferta perfeitamente elästica). 
O trabalho mostra-se bastante interessante, desenvolvendo um modelo de demanda, estimando as respectivas elasticidades-renda da absorção de caloria e proteína para cada estrato, através das seguintes för mulas:

$$
\begin{gathered}
\rho c(m)=\frac{\sum_{i=1}^{A} c_{i} q_{i}(m) \varepsilon_{i}(m)}{\sum_{i=1}^{A} c_{i} q_{i}(m)}, e \\
\rho p r(m)=\frac{\sum_{i=1}^{A} p r_{i} q_{i}(m) \varepsilon_{i}(m)}{\sum_{i=1}^{A} p r_{i} q_{i}(m)}
\end{gathered}
$$

onde :

$\rho c(m)$ é a elasticidade-renda da absorção calörica no estrato $\underline{m}$. $\rho p r(m)$ é a elasticidade-renda da absorção protēica no estrato m. A é o nümero de produtos considerados.

$c_{i}$ é o coeficiente de transformação do produto I em calorias. $\mathrm{pr}_{i}$ ë o coeficiente de transformação do produto i em proteínas. $q_{i}(m)$ é a quantidade consumida do produto $\underline{i}$, no estrato $\underline{m}$. $\varepsilon_{\mathrm{i}}(\mathrm{m})$ é a elasticidade-renda da demanda do produto $\underline{i}$, no estrato $\underline{\mathrm{m}}$. Três hipōteses foram feitas sobre a distribuição de renda: a) aumento da renda dos estratos deficientes em calorias e proteínas, per manecendo constante a renda dos outros estratos; b) redistribuição da ren da do estrato mais elevado para os estratos com deficiências calórico-pro têicas, permanecendo constante a renda total; c) redução da renda do es trato mais elevado, permanecendo constante os outros estratos de renda. 
Constataram inicialmente, a existência de uma distribuição de calorias e proteinas muito desigual, favorecendo as classes de ren da mais alta. Contudo, a distribuição do consumo de calorias mostra-se menos assimétrica do que a de proteinas e enquanto a deficiência protéica estä presente em dois dos cinco esträtos considerados, a escassez de calorias surge somente em um estrato.

Outro ponto relevante è o fato de a elasticidade de absorção de calorias se apresentar constantemente com valores menores do que a protèica, como pode ser observado pela Tabela 4.

Tabela 4. Elasticidade-renda de absorção de calorias e proteinas

\begin{tabular}{lcccccc}
\hline & \multicolumn{5}{c}{ Estratos de renda } & Mëdia \\
\cline { 2 - 6 } Alimentos & 1 & 11 & 111 & IV & V & \\
\hline calorias & 0,69 & 0,69 & 0,60 & 0,35 & 0,23 & 0,51 \\
proteinas & 0,92 & 0,90 & 0,73 & 0,50 & 0,35 & 0,65 \\
\hline
\end{tabular}

Fonte: PINSTRUP e CAICEDO (1978)

Em relação à redistribuição de renda, as anälises mostraram que, em ambas as pressuposições de oferta, para se obter um impacto mais efetivo sobre as deficiências dos dois nutrientes seria adequado uma redução das rendas dos grupos de niveis elevados em favor dos estratos me nos favorecidos.

A contribuição significativa da pesquisa foi o desenvolvimento da metodologia descrita para o cälculo dos respectivos coeficientes, os quais expressam a relação entre a variação da absorção de caloria 
ou proteína frente à variação da renda para cada nível de renda em particular.

Essa retrospectiva não abrange todos os tipos de trabalhos desenvolvidos sobre o consumo de alimentos, mas procura situar aqueles que serviram de base para esta pesquisa.

De maneira geral, após esta breve revisão, dois pontos podem ser salientados. Não existe uma função adequada e geral para o cālculo dos coeficientes de elasticidade-renda. Cada aytor adota a que melhor se adapta às características da sua pesquisa. A maioriados trabalhos mostra que hä diferenciação no consumo de alimentos entre os diferentes niveis de renda. Parece aconselhävel, então, determinar elasticidadesrenda para os diferentes estratos de renda e concomitantemente efetuar projeções específicas para as faixas de renda adotadas.

Cabe ainda acrescentar que as comparações entre coeficientes de elasticidade obtidos em diferentes trabalhos ficam dificultadas pe lo fato de os autores adotarem diferentes critérios de estratificação da população e também por não haver homogeneidade na definição dos alimentos ou grupos de alimentos analisados. 
3. METODOLOGIA

A metodologia do presente trabalho pode ser separada em duas etapas. A primeira consiste na obtenção dos coeficientes de elasticidade-renda da demanda dos alimentos para diferentes estratos de renda, e a segunda refere-se à obtenção de projeções de demanda de produtos ali menticios com hipōteses alternativas de redistribuição de renda.

o desenvolvimento dessa metodologia è de interesse para o aprofundamento dos estudos sobre estrutura de consumo de alimentos que levem em consideração a distribuição da renda, principalmente para os paí ses subdesenvolvidos, os quais apresentam problemas graves de alimentação, especialmente no que se refere à heterogeneidade da estrutura de con sumo.

Inicialmente serä apresentado um breve resumo das caracteristicas da pesquisa de orçamentos familiares realizada pelo Instituto Brasileiro de Geografia e Estatística (IBGE), atravēs do ENDEF - Estudo Na cional da Despesa Familiar-, no período de agosto de 1974 a agosto de 1975, a qual forneceu os dados para o presente trabalho. 
A seguir serão expostos os métodos utilizados na anälise da estrutura da demanda.

3.1. Características do Levantamento e Apresentação dos Dados do Estudo Nacional da Despesa Familiar (ENDEF).

O objetivo prioritärio da FIBGE ao realizar uma ampla pesquisa nacional sobre orçamentos familiares foi o de obter informações pre cisas sobre consumo alimentar das familias, as quais pudessem ser analisadas em um contexto de informações sōcio-econômicas globais. Assim, foram coletados dados sobre o consumo familiar em termos de quantidades, dispêndios e origem dos alimentos, além de outros dados referentes às características sōcio-econômicas das famílias constituintes da amostra.

Os produtos incluidos no levantamento foram selecionados levando em consideração sua importância no total das despesas das famílias e sua frequência. Calcularam-se as despesas baseadas nos preços de agosto de 1974, período básico das informações sobre os gastos anuais.

Foi decidido utilizar períodos de referência específicos para os värios itens da despesa, considerando a frequência de ocorrência de cada um, visando aumentar o grau de confiabilidade das informações que dependem da memória dos entrevistados.

Como indicação da boa qualidade das informações coletadas, tem-se o fato desta pesquisa ter-se realizado em um trabalho conjunto com especialistas da Divisão de Nutrição da FAO (Food And Agricultural Organi zation), organização que tem ampla experiência em estudos dessa natureza. 
A amostra consistiu de aproximadamente 55.000 familias das "regiões da PNAD", onde foi considerada como familia o "conjunto de pessoas - ligadas ou não por laços de parentesco - que participam da forma ção e utilização de um mesmo orçamento, compartilham das refeições e habitam um mesmo domicilio particular". Assim, pertencem ao grupo: o chefe, mulher e filhos solteiros, filhos casados, desquitados ou viúvos, parentes e agregados, desde que concorram para a formação de um orçamento comum-

Para os objetivos deste trabalho, interessaram os dados re ferentes às despesas (monetäria e não monetäria) anuais por família em alimentos, por classe de despesa global, referentes ao Estado de São Pau10. A amostra para esse estado engloba 7.094 domicilios assim distribuidos:

- Area metropolitana de São Paulo 2.852

- Area urbana não-metropolitana $\quad 3.192$

- Area rural $\quad 1.050$

Os limites das classes de despesa foram estabelecidos com base no maior salärio-mínimo mensal vigente no país em agosto de 1974 $\operatorname{Cr} \$ 376,80-$, o qual equivale a aproximadamente $\operatorname{Cr} \$ 4.500,00$, em termos anuais.

Os dados foram obtidos por domicilio e apresentados agrupados em nove classes de despesa familiar, conforme se pode verificar nas Tabelas 5 e 6 .

II ENDEF (1978) 
Tabela 5. Classes de despesas para o Estado de São Paulo, área metropolitana de São Paulo e ärea urbana não-metropolitana

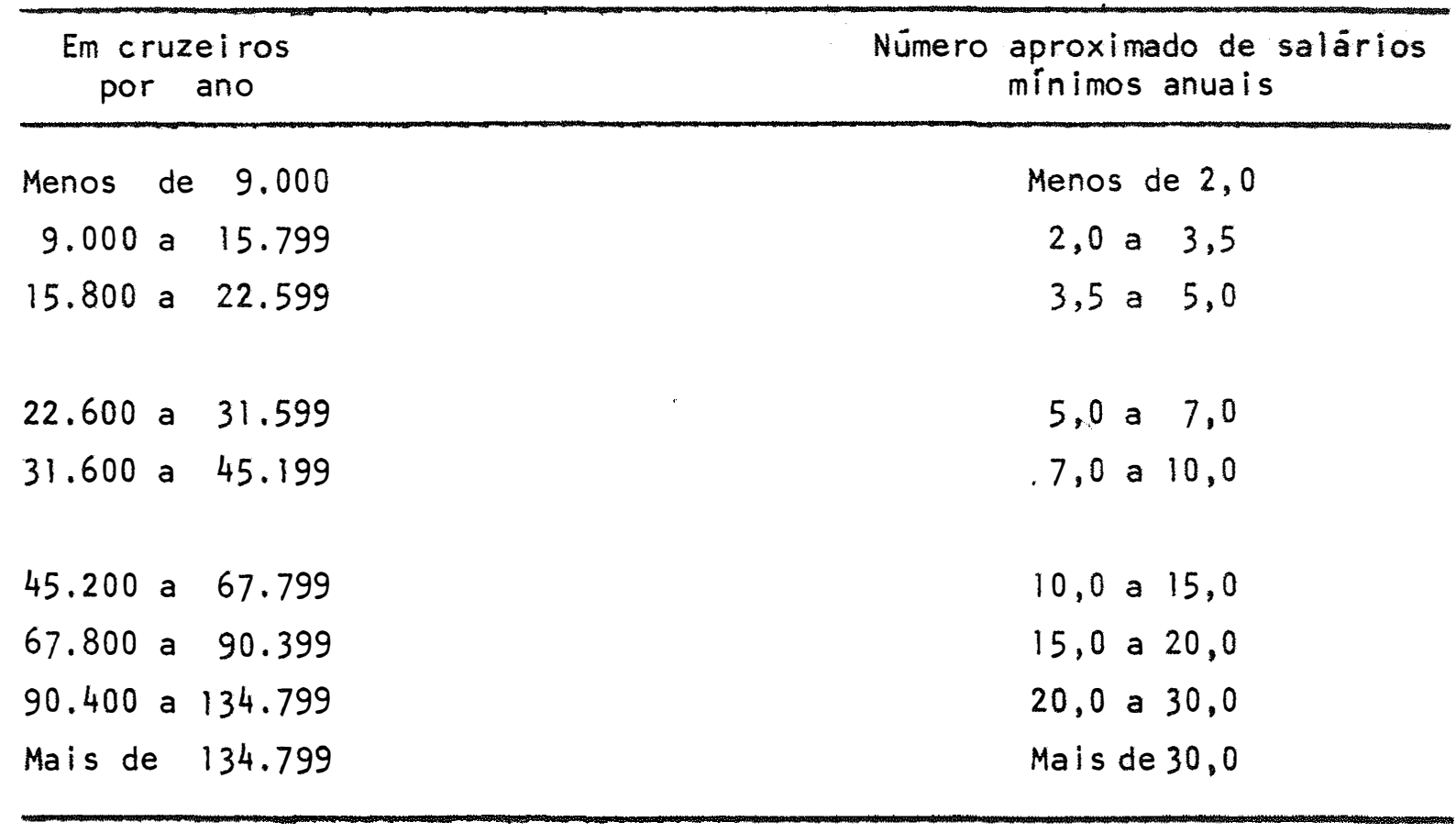

Tabela 6. Classes de despesas para a ärea rural do Estado de São Paulo

\begin{tabular}{cr}
\hline $\begin{array}{c}\text { Em cruzeiros } \\
\text { por ano }\end{array}$ & $\begin{array}{c}\text { Número de salärios } \\
\text { mínimos anuais }\end{array}$ \\
\hline $\begin{array}{l}\text { Menos de } 4.500 \\
4.500 \text { a } 5.599\end{array}$ & $\begin{array}{r}\text { Menos de } 1,00 \\
5.600 \text { a } 7.899\end{array}$ \\
7.900 a 8.999 & 1,25 a 1,75 \\
9.000 a 11.299 & 1,75 a 2,00 \\
11.300 a 15.799 & 2,00 a 2,50 \\
15.800 a 22.599 & 2,50 a 3,50 \\
22.600 a 31.599 & 3,50 a 5,00 \\
Mais de 31.599 & 5,00 a 7,00 \\
\hline
\end{tabular}


Considerando o fato de que as estruturas das necessidades das familias com diferentes rendas são distintas, apresentando uma família de renda elevada uma estrutura de necessidades diversa e um estilo de vida diferente daquele de uma familia com renda mais baixa, necessário se faz estratificar as familias constituintes da amostra conforme sua renda.

Ressalte-se, entretanto, que os dados do ENDEF disponiveis não permitem esse tipo de classificação. Foi utilizada, então, a estratificação das familias segundo o montante de despesas.

Tendo em vista as anālises estatisticas apresentadas adian te, os nove estratos de despesa foram agrupados em três grandes classes ou estratos para as áreas urbanas e área rural, conforme mostra a Tabela 7. 
Tabela 7. Estratificação da amostra segundo os Estratos de Despesa Glo bal

\begin{tabular}{|c|c|c|c|c|c|}
\hline & \multirow{2}{*}{$\begin{array}{c}\text { Estratos } \\
\text { de } \\
\text { despesa } \\
\text { global }\end{array}$} & \multirow{2}{*}{$\begin{array}{c}\text { Estratos } \\
\text { do } \\
\text { ENDEF } \\
\text { abrangidos }\end{array}$} & \multirow{2}{*}{$\begin{array}{l}\text { Limites dos } \\
\text { Estratos em } \\
\text { Salärios } \\
\text { Minimosa/ }\end{array}$} & \multicolumn{2}{|c|}{ Familias } \\
\hline & & & & No & $\%$ \\
\hline \multirow{3}{*}{$\begin{array}{l}\text { Estado de } \\
\text { São Paulo }\end{array}$} & 1 & 19 a 39 & 0 a 5 & 1955 & 46,90 \\
\hline & 2 & $4 !$ e $5 ?$ & 5 a. 10 & 1188 & 28,50 \\
\hline & 3 & $6 \%$ a $9 ?$ & mais de 10 & 1025 & 24,59 \\
\hline Total & & & & 4168 & 100,00 \\
\hline \multirow{3}{*}{$\begin{array}{l}\text { Área } \\
\text { metropol itana }\end{array}$} & 1 & $1 \div$ a 39 & 0 a 5 & 717 & 34,49 \\
\hline & 2 & $4 !$ e $5 ?$ & 5 a 10 & 673 & 32,37 \\
\hline & 3 & $6 !$ a 99 & mais de 10 & 689 & 33,14 \\
\hline Total & & & & 2079 & 100,00 \\
\hline \multirow{3}{*}{$\begin{array}{l}\text { Area urbana } \\
\text { näo-metropol itana }\end{array}$} & 1 & 19 a 39 & 0 a 5 & 699 & 49,43 \\
\hline & 2 & $4 !$ e $5 ?$ & 5 a 10 & 418 & 29,56 \\
\hline & 3 & $6:$ a $9 ?$ & mais de 10 & 297 & 21,00 \\
\hline \multirow[t]{2}{*}{ Total } & & & & 1414 & 100,00 \\
\hline & 1 & 19 a $5 \%$ & 0 a 2,50 & 294 & 43,36 \\
\hline \multirow[t]{2}{*}{ Area rural } & 2 & $6:$ e $7 !$ & 2,50 a 5,00 & 247 & 36,43 \\
\hline & 3 & 80 e $9 ?$ & mais de 5,00 & 137 & 20,21 \\
\hline Total & & & & 678 & 100,00 \\
\hline
\end{tabular}

al Salärios mínimos aproximados 


\subsection{Demanda de Alimentos}

O consumo de um modo geral é afetado por inümeros fatores sociais e econômicos, os quais podem alterar-se no decorrer de certo período de tempo- 81 .

Alēm do preço do produto, a magnitude da procura pode ser afetada por quatro fatores fundamentais: nivel e distribuição da renda, os preços de produtos substitutos e complementares, processos de urbanização e mudanças nos gostos ou preferências dos consumidores.

Todavia, entre estes podemos destacar a renda como variável primordial na determinação do comportamento do consumidor, influência esta amplamente evidenciada nos estudos de demanda, baseados em sēries cronolögicas ou em estudos tipo "cross-section" (corte transversal no tem po).

Um dos primeiros estudos a comprovar esta relação foi realizado por Ernest Engel, estatístico alemão do século $X \mid X$, o qual formulou uma lei conhecida como Lei de Engel em que afirma: "á medida que cresce a renda, diminui a participação dos gastos com alimentos". Em outras palavras, à medida que a renda se eleva, a propensão média a consumir em alimentos diminui.

8/ ACKLEY (1969) relata a influência de diversos fatores sobre o consumo. 
Pode-se destacar também estudo realizado pela FAO, onde foi analisado o comportamento dos consumidores frente a suas rendas, atra vës das respectivas elasticidades-renda dos produtos alimentícios escoIhidos, em mais de cem países, abrangendo diferentes regiōes do mundo. Fo ram feitas projeções considerando a população e a renda como os determinantes básicos da quantidade demandada.

Segundo a FAO, a inclusão do fator população nas projeções de demanda é de grande importância, pois devido ao processo de desenvolvimento econômico a composição etária da população se altera substancialmente e com ela a estrutura da demanda. Esta entidade afirma que nos paí ses em desenvolvimento aproximadamente $70 \%$ do aumento da demanda de al imentos è ocasionada pelo aumento da população e somente $30 \%$ devido a aumentos na renda per capita (FAO, 1971).

Em relação à influência do crescimento da renda média per capita sobre o nível de consumo, evidentemente esta variável não engloba toda a informação necessária, devido à importância da distribuição da ren da e de sua variação no decorrer do tempo como determinantes da demanda. Estimativas de projeções de demanda que não consideram este fator tendem a apresentar erros significativos, no que diz respeito a uma projeçãomais realista da demanda. M. de Nigris, em estudos da FAO, realizados em värios países latino-americanos, chega a esta conclusão (FAO, 1972). Embora a inclusão deste parâmetro apresente certas dificuldades, como por exemplo a introdução sistemática da mesma dentro do modelo de projeção, e a falta de dados a esse respeito, o autor considera mais välido estabelecer certas hipōteses sobre a distribuição de renda do que não levar em 
conta este fator ao efetuar este tipo de anälise.

A estrutura de preços relativos é também, em grande medida, um determinante do nivel de consumo. Sabe-se que qualquer mudança nos preços produz alterações na procura do consumidor determinada por dois efeitos: substituição e renda. 0 efeito-substituição conduz o consumidor a substituir os bens cujos preços estejam relativamente altos por outros de preços relativamente mais baixos. O efeito-renda ocorre porque uma elevação de preço (com renda monetäria constante) diminui a renda real do consumidor, induzindo-o a adquirir quantidades menores dos bens normais.

O efeito da variação dos preços pode ser significativo e modificar substancialmente a demanda se considerarmos um período relativamente longo, o qual produza desníveis na oferta e demanda dos produtos, alterando assim a estrutura de preços. Mas tal fato poderá ser desprezado se o horizonte de projeção da demanda for relativamente curto; isto porque os preços relativos das categorias importantes de bens modificam-se muito pouco (ACKLEY, 1969).

Um outro impacto sobre a demanda è o causado pelo grau de urbanização da população. Procura-se, através desta variāvel, detectar alterações nos häbitos dos corisumidores, especialmente em relação à qualidade dos alimentos. Nesta pesquisa, como as projeções são feitas separadamente para as äreas urbanas e a área rural, a urbanização é levada em consideração. 


\subsection{Mëtodos}

3.3.1. Coeficientes de Elasticidade

3.3 .1 .1 . A função log-inversa

Quando se trata de analisar as relações existentes entre as variações da renda e da quantidade demandada, è de grande importância determinar a elasticidade-renda da procura. Esta expressa a variação relativa na quantidade procurada do produto quando ocorrem variações na ren da.

$$
\begin{gathered}
\text { Considera-se a função log-inversa } \\
\qquad C=A e^{-B / Y}
\end{gathered}
$$

onde :

$A$ e $B$ são parâmetros,

C é o consumo ou dispêndio de uma dada categoria de alimento, e y al è a renda.

Uma vez que não existe um modelo "ótimo" e de aplicação ge ral, decidiu-se pela função log-inversa em analogia à metodologia utilizada por Ateaga e Martínez (1973). Esta função se aplica ao caso de produtos cujo consumo tende a uma assíntota ou nivel de saturação com o cres cimento da renda, como è o caso dos alimentos.

al Neste trabalho a despesa global por familia é utilizada em lugar da renda. De acordo com ENDEF (1978, p.17), "a despesa global inclui todas as despesas - monetärias e não monetärias - realizadas pela família na aquisição de bens e serviços de qualquer tipo e natureza. Portanto, inclui as despesas correntes (consumo e impostos etc.), o aumento do ativo e a diminuição do passivo". Assim sendo, a despesa global pode ser considerada igual à renda por família. 
Cabe assinalar que esta função serā utilizada, nas projeções feitas neste trabalho, apenas para estimar o coeficiente de elasticidade-renda, e não para estimar diretamente a quantidade consumida. Seria interessante fazer as projeções utilizando coeficientes de elasticidaderenda estimados atravēs de outras funções com o intuito de testar e comparar os resultados, o que, no entanto, não constitui o objetivo deste trabaltho.

A elasticidade-renda da demanda que se deriva desta função ë definida por

$$
n=B / Y
$$

podendo representar bens superiores ou inferiores, segundo o sinal do parâmetro $B$ se apresente positivo ou negativo, respectivamente, Nos dois casos o valor absoluto dos coeficientes de elasticidade-renda da demanda tende a infinito à medida que a renda tende a zero, e tende a zero à medida que a renda tende a infinito.

Quando B apresenta-se maior do que zero, existe um ponto de inflexão para $Y=B / 2$. A esquerda desse ponto, a declividade cresce ã medida que Y cresce; à direita dele, a declividade decresce, conforme Figura 1. 


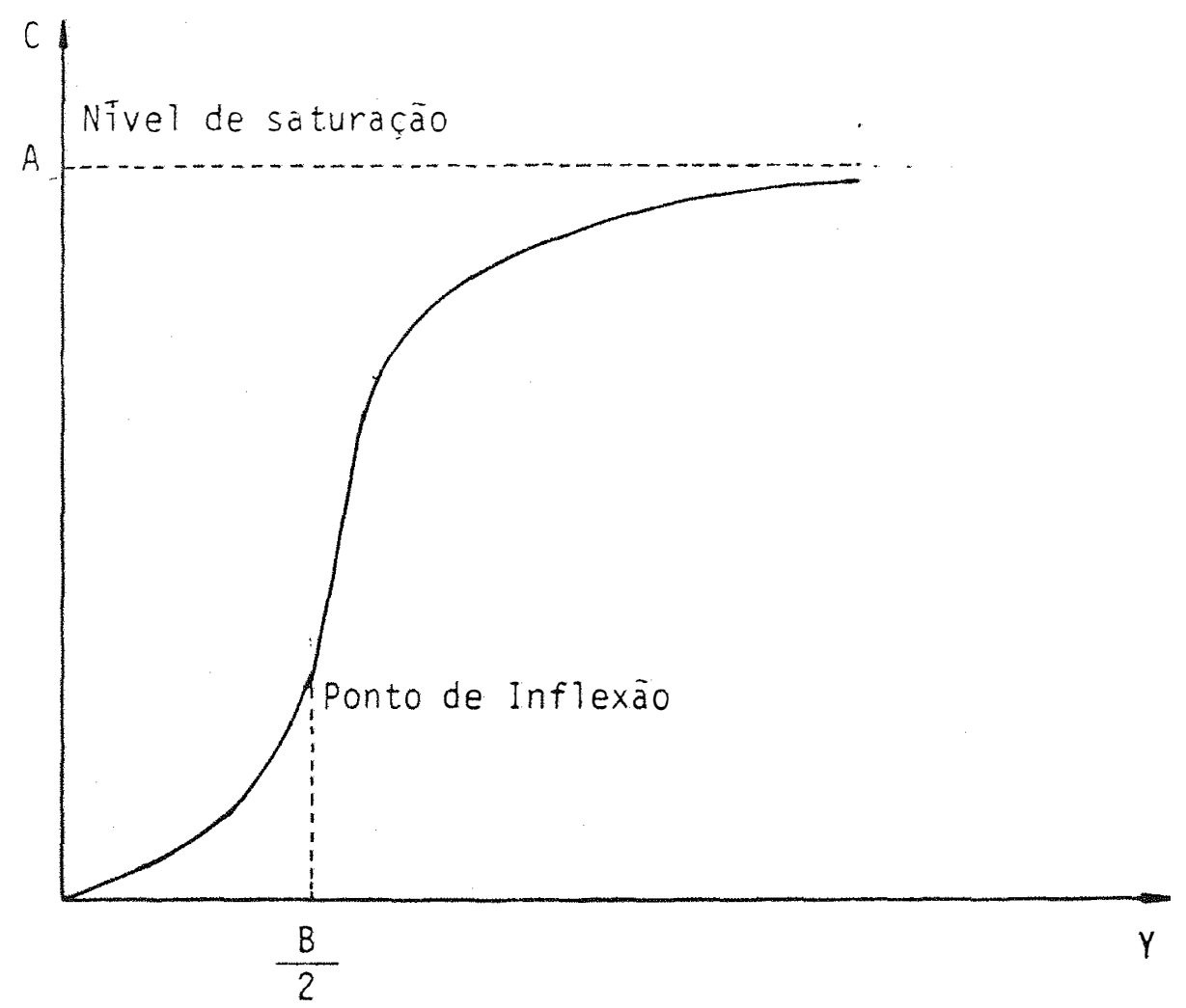

Figura 1. Curva de Engel para bens superiores, admitindo-se que seja uma função log-inversa

A elasticidade-renda média da demanda é dada por

$$
\bar{n}=B / \bar{Y}
$$

onde $\bar{Y}$ representa a renda familiar mëdia da população. De modo análogo, a elasticidade-renda da demanda para um determinado grupo de consumidores ¿ é representada por

$$
n_{j}=B / Y_{j},
$$

onde $Y_{j}$ é a renda familiar média do grupo. 
Das expressões (2) e (3), obtēm-se:

$$
\eta_{j}=\bar{\eta} \bar{Y} / Y_{j}
$$

expressando elasticidades específicas para cada estrato de renda em função da elasticidade-renda média. Entretanto, esta expressão define elasticidade-renda da demanda para diferentes grupos de renda em um corte transversal no tempo, sendo necessário modificä-la quando se trabalha com um modelo intertemporal. Isto porque, devido ao processo de desenvolvimento econômico, a renda da população cresce no decorrer do tempo, alterando a renda média e consequentemente a elasticidade. Deste modo, a elasticidade que se utiliza nas projeções de demanda de alimentos é representada por

$$
n_{j t}=\bar{n}_{0} \bar{Y}_{0} / Y_{j t}
$$

onde:

$\eta_{j t}$ ë a elasticidade-renda do grupo $\underline{j}$, no periodo $\underline{t}$,

$Y_{j t}$ ë a renda média do grupo $\mathfrak{j}$, no período $\underline{t}$,

$\bar{Y}_{0}$ é a renda média no ano base, e

$\bar{n}_{0}$ è a elasticidade-renda média correspondente ao nível de renda $\bar{Y}_{0}$

Esta relação mostra o comportamento das elasticidades através do tempo, quando ocorrem variações na renda, expressão utilizada por Ateaga e Martinez (1973). 


\subsubsection{A Poligonal}

Com o objetivo de realizar comparações entre as elasticidades-renda obtidas para os estratos da amostra, utiliza-se um segundo método para obtenção das elasticidades-renda da demanda. Este consistiu no ajuste de uma poligonal aos dados, método escolhido por permitir testar diretamente as diferenças entre elasticidades nos estratos considerados.

0 modelo estatístico adotado ë:

$$
\log C_{j}=\alpha+\beta \log \gamma_{j}+\sum_{i=1}^{m} \gamma_{i} z_{i j}\left(\log \gamma_{j}-k_{i}\right)+u_{j}
$$

onde:

$c_{j}$ é a despesa de consumo por família no j-ësimo estrato,

$Y_{j}$ é a despesa global por familia no j-ësimo estrato,

$z_{i j}$ são variăveis binärias,

$m$ é o nümero de vërtices da poligonal,

$K_{i}$ são as abcissas dos vērtices, e

$\alpha, \beta$ e $\gamma_{i}(i=1, \ldots, n)$ são parâmetros e os $u_{j}$ são resíduos.

Considera-se, neste trabalho, o ajuste de uma poligonal com dois vértices para três estratos ou fases, 0 modelo permite generalização para qualquer número de estratos $9 /$. A Figura 2 apresenta o tipo de poligonal esperada.

$$
\begin{aligned}
& \text { A estimativa da equação dessa poligonal é: } \\
& \hat{W}=a+b \log Y+c Z_{1}\left(\log Y-K_{a}\right)+d Z_{2}\left(\log Y-K_{b}\right)
\end{aligned}
$$

g/ Ver HOFFMANN E VIEIRA (1977). 
onde:

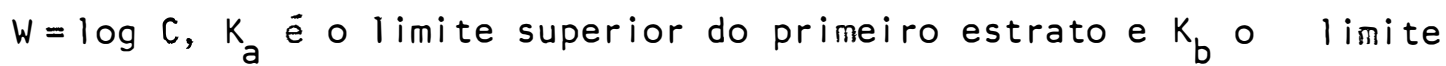
superior do segundo estratoll.

As variāveis binārias (variāveis "dummy") $z_{1}$ e $z_{2}$ assumem os valores:

$\begin{array}{lll}Z_{1}=0 & \text { se } & \log Y \leqslant k_{a} e, \\ Z_{1}=1 & \text { se } & \log Y>K_{a} \\ Z_{2}=0 & \text { se } & \log Y \leqslant K_{b} e, . \\ z_{2}=1 & \text { se } & \log Y>K_{b}\end{array}$

Nestas condições, obtèm-se

$\widehat{W}=a+b \log Y$ para o primeiro estrato;

$\hat{W}=a-c K_{a}+(b+c) \log Y$ para o segundo estrato; com

$\left(a-c K_{a}\right)$ correspondendo ao termo constante e $(b+c)$ correspondendo ao coeficiente angular e;

$$
\varpi=a-c K_{a}-d K_{b}+(b+c+d) \log Y \text { para o terceiro es- }
$$

trato, com $\left(a-c K_{a}-d K_{b}\right)$ correspondendo ao termo constante $e(b+c+d)$ correspondendo ao coeficiente angular.

10/ Para os valores de $k_{a}$ e $k_{b}$ olhar as tabelas 5,6 e $7, p .26$ e 28. 


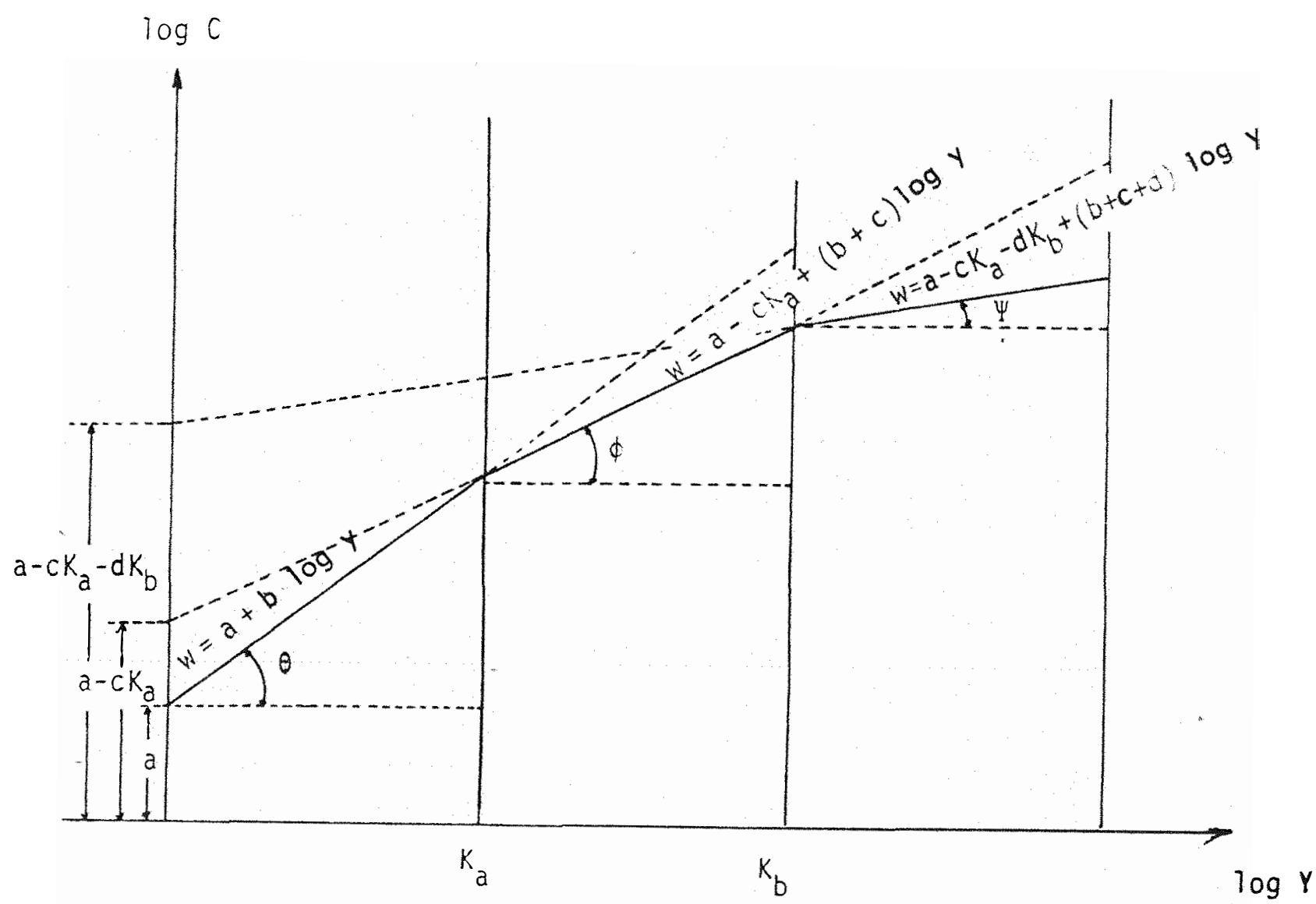

Figura 2. Representação gräfica de uma poligonal (temos tg $\theta=b$; $\operatorname{tg} \phi=b+c ; \operatorname{tg} \psi=b+c+d)$

As estimativas dos coeficientes de elasticidade-renda são b no primeiro estrato, $b+c$ no segundo estrato $e$ $b+c+d$ no terceiro estrato. 
Sejam $\beta, \gamma, \delta$ os valores dos parâmetros cujas estimativas são b, c e d, respectivamente. Para testar se a elasticidade no 2 ? estra to é diferente da elasticidade no 1 : estrato, isto é, para testar se $\beta=\beta+\gamma$, basta testar a hipótese $H_{0}: \gamma=0$. Analogamente, para testar se há variação do valor do coeficiente de elasticidade do 2 ? ao 3 ? estrato, basta testar $H_{0}: \delta=0$.

Os dados utilizados consistem na despesa global e despesa com cada grupo de alimento, por família, nos 9 estratos de despesa global do ENDEF. Assim o ajustamento das regressões $\vec{e}$ sempre feito com base em "g observações" ou 9 pontos. Para fins de anälise estatística, o resí duo ficou com 7 graus de liberdade no caso do ajustamento da log - inversa e 5 graus de liberdade no caso do ajustamento da poligonal.

Uma vez que os dados utilizados consistem no dispêndio familiar médio, foi utilizado o método de mínimos quadrados ponderados para obter as estimativas dos parâmetros. O fator de ponderação è o nümero de familias em cada um dos 9 estratos.

\subsubsection{Modelo de Projeção da Demanda}

Para projeção da demanda de alimentos utiliza-se um modelo mạtemātico, simulando diferentes alternativas de crescimento da renda e diferentes políticas de redistribuição da renda.

Ressalte-se que o modelo considera expressamente como variāveis determinantes da demanda a população, o nível de renda e sua distribuição. Supõe-se uma composição etäria da população e uma estrutura de 
preços relativos constantes. Acredita-se que tais pressuposições กão constituem limitações muito sérias para o modelo.

\section{$3.3,2,1$. Modelo Bäsico}

Supondo o consumo por família como função do nível de renda, pode-se determinar o crescimento do consumo atravēs da relação:

$$
\Delta C_{t} / C_{t-1}=n_{t} \Delta Y_{t} / Y_{t-1}
$$

onde:

$$
\begin{aligned}
& c_{t-1} \text { é o consumo por familia no período } t-1 \text {. } \\
& \Delta C_{t}=C_{t}-C_{t-1} \text { é a variação do consumo entre o período } t \text { e } t-1 \text {. } \\
& Y_{t-1} \text { é a renda no período } t-1 \text {. } \\
& \Delta Y_{t}=Y_{t}-Y_{t-1} \vec{e} \text { a variação da renda entre o período } t \text { e } t-1 \text {. } \\
& \eta_{t} \text { é a elasticidade-renda da demandal }
\end{aligned}
$$

Desenvolvendo a relação, obtëm-se o consumo em função da elasticidade-renda, do consumo do período anterior e da variação porcentual da renda.

$$
c_{t}=\left(1+n_{t} \Delta Y_{t} / Y_{t-1}\right) c_{t-1}
$$

a/ determinada com base na função log-inversa, utilizando-se, de acordo com (1), a expressão

$$
n_{t}=\frac{\frac{B}{Y_{t}+Y_{t-1}}}{2}
$$


Substituindo os valores de $t=1,2, \ldots, n$ chega-se ao modelo geral,

$$
c_{t}=c_{0} \prod_{\tau=1}^{t}\left(1+n_{\tau} \Delta Y_{\tau} / Y_{\tau-1}\right)
$$

o qual expressa o consumo por família no ano t em função do consumo do ano-base, da elasticidade-renda da demanda e da variação porcentual da renda.

De modo anālogo, expressa-se o nümero de famílias de um determinado ano em função do nümero de famílias de um, ano-base, de acordo com a seguinte relação

$$
P_{t}=P_{0} \prod_{\tau=1}^{t}\left(1+\Delta P_{\tau} / P_{\tau-1}\right)
$$

Considerando que a quantidade total demandada no período t é expressa pela relação

$$
D_{t}=C_{t} \cdot P_{t}
$$

o consumo total no período t è representado por:

$$
D_{t}=C_{0} P_{0} \prod_{\tau=1}^{t}\left(1+\Delta P_{\tau} / P_{\tau-1}\right)\left(1+n_{\tau} \Delta Y_{\tau} / Y_{\tau-1}\right)
$$

\subsubsection{Modelo com Redistribuição de Renda}

Para a anālise do efeito da redistribuição de renda sobre os diferentes níveis de dispêndio em consumo alimentar, procede-se a uma alteração no modelo básiço, objetivando medir o impacto de políticas alternativas de redistribuição de renda sobre as respectivas estruturas de consumo. 
Em relação à população, utiliza-se taxas anuais de crescimento especificas para cada uma das áreas em estudo.

Foram adotadas as seguintes taxas anuais de crescimento populaciona 1: 3,4\% para o Estado de São Paulo, 5,5\% para a ärea metropolitana e 4,28\% para a ärea urbana não-metropolitanall/. Fixadas tais taxas de crescimento populacional, a taxa de crescimento da população rural pode ser deduzida, obtendo-se os valores apresentados na Tabela 8.

Nas projeções de demanda por alimentos consideram-se duas hipóteses sobre a distribuição de renda.

$11 /$ FONTE: SECRETARIA DE ECONOMIA E PLANEJAMENTO (1978). Projeções da população para o Estado de São Paulo - 1970/1990 - Um Estudo Demográfi co. Na ocasião em que foram calculadas as projeções realizadas neste trabalho, ainda não estavam disponíveis os resultados do Censo Demogräfico de 1980. Esses resultados obviamente levariam a considerar taxas de crescimento populacional diferentes, embora não houvesse alterações drästicas. 
Tabela 8. Taxas anuais de crescimento populacional da ärea rural. Período $1974-1984$

Período

\begin{tabular}{lc}
\hline $1974-1975$ & $-0,95$ \\
$1975-1976$ & $-0,94$ \\
$1976-1977$ & $-0,93$ \\
$1977-1978$ & $-0,92$ \\
$1978-1979$ & $-0,90$ \\
$1979-1980$ & $-0,88$ \\
$1980-1981$ & $-0,85$ \\
$1981-1982$ & $-0,81$ \\
$1982-1983$ & $-0,73$ \\
$1983-1984$ & $-0,60$ \\
\hline
\end{tabular}

Periodo

Taxa Anual de Crescimentoal

(\%)

a/ Estimada atravēs da fórmula

$$
P_{t}=P_{t-1}(1+p)=P_{t-1,1}\left(1+p_{1}\right)+P_{t-1,2}\left(1+p_{2}\right)+P_{t-1,3}\left(1+p_{3}\right) \text {. }
$$$$
\text { onde } P_{t} \text { representa a população do estado no } t \text {-ésimo ano, }\left(P_{t-1, k}\right) \text { com }
$$
$K=1,2,3$ representa a população da K-ēsima ärea (metropolitana, urbana não-metropolitana ou rural) no ano anterior, $p$ representa a taxa anual de crescimento da população do estado e $p_{K}$ representa a taxa anual de crescimento da k-ësima ärea. 
Na primeira hipótese admite-se que a distribuição de renda se mantëm constante durante o periodo de projeção 1974-1984, considerando-se uma mesma taxa de crescimento da renda familiar para os três grandes estratos, de $3,5 \%$ ao ano12/. A mesma taxa foi adotada tanto para as äreas urbanas como para a ärea rural.

Na segunda hipōtese simula-se uma redistribuição de renda moderada em favor das classes baixa e média, adotando-se as seguintes taxas de crescimento da renda familiar: $3,5 \%$ para a mëdia da população, $2 \%$ para o terceiro estrato e $4 \%$ para o segundo estrato. Admitem-se as mesmas taxas para as quatro äreas em estudo. Fixadas as taxas de crescimento da renda global e dos dois estratos superiores, a taxa de crescimento da renda do primeiro estrato fica determinada atravēs da förmula:

$$
r_{1}=\frac{1}{v_{t-1,1}}\left(v_{t-1} r-v_{t-1,2} r_{2}-v_{t-1,3} r_{3}\right)
$$

Para o Estado de São Paulo admite-se ainda uma terceira hipótese relativa à distribuição de renda, um pouco mais drästica. Adotam-se as seguintes taxas de crescimento da renda familiar: $3,5 \%$ para a média da população, $0 \%$ para o terceiro estrato e $4 \%$ para o segundo estrato, obtendo-se para o primeiro estrato as taxas apresentadas na Tabela 9.

12/ Essa taxa foi estabelecida considerando as taxas de crescimento obser vadas em anos recentes no Brasil (vide Conjuntura Econômica. 33(12)." 
Tabela 9. Taxas anuais de crescimento da renda familiar no primeiro estrato de renda para as áreas urbanas e ärea rural. Periodo $1974-1984$

\begin{tabular}{|c|c|c|c|c|c|}
\hline \multirow[b]{2}{*}{ Período } & \multicolumn{4}{|c|}{ Redistribuição Média } & \multirow{2}{*}{$\begin{array}{r}\text { Redist.Drästica } \\
\text { Estado de } \\
\text { São Paulo }\end{array}$} \\
\hline & $\begin{array}{l}\text { Estado } \\
\text { de São } \\
\text { Paulo }\end{array}$ & $\begin{array}{l}\text { Area } \\
\text { Metrop. }\end{array}$ & $\begin{array}{l}\text { Area Urba } \\
\text { na Não-- } \\
\text { Metrop. }\end{array}$ & $\begin{array}{l}\text { Area } \\
\text { Rural }\end{array}$ & \\
\hline $1974-1975$ & 9,3 & 14,2 & 7,0 & 7,5 & 18,1 \\
\hline $1975-1976$ & 8,9 & 13,0 & 6,9 & 7,2 & 15,8 \\
\hline $1976-1977$ & 8,6 & 12,0 & 6,7 & 7,0 & 14,1 \\
\hline $1977-1978$ & 8,3 & 11,3 & 6,6 & 6,9 & 12,8 \\
\hline $1978-1979$ & 8,0 & 10,6 & 6,4 & 6,7 & 11.7 \\
\hline $1979-1980$ & 7,7 & 10,0 & 6,3 & 6,5 & 10,8 \\
\hline $1980-1981$ & 7,5 & 9,6 & 6,2 & 6,4 & 10,1 \\
\hline $1981-1982$ & 7,3 & 9,1 & 6,0 & 6,3 & 9.5 \\
\hline $1982-1983$ & 7,0 & 8,8 & 5,9 & 6,1 & 9,0 \\
\hline $1983-1984$ & 6,9 & 8,4 & 5,8 & 6,0 & 8,5 \\
\hline
\end{tabular}

A quantidade total demandada pelas familias de determinado estrato de renda ou despesa global é dada por

$$
D_{j t}=C_{j t} \cdot P_{j t}
$$


onde:

j è o estrato de renda, e

t é o ano considerado.

Somando os niveis de demanda de cada estrato de renda e expressando-os em função da população e do consumo familiar no ano-base e das correspondentes taxas de crescimento, obtēm-se a seguinte relação:

$$
D_{t}=\sum_{j=1}^{3} P_{0 j} C_{0 j} \prod_{\tau=1}^{t}\left(1+\Delta P_{j \tau} / P_{j \tau-1}\right)\left(1+n_{j \cdot \tau} \Delta Y_{j \tau} / Y_{j \tau-1}\right)
$$

Como a taxa de crescimento da população $\left(p_{\tau}\right)$ é a mesma para todos os estratos e indicando a taxa de crescimento da renda familiar por $r_{j \tau}$, obtemos

$$
D_{t}=\sum_{j=1}^{3} P_{0 j} C_{0 j} \prod_{\tau=1}^{t}\left(1+P_{\tau}\right)\left(1+\eta_{j \tau} r_{j \tau}\right)
$$

Finalmente, no caso das áreas urbanas, com taxa de crescimento da população $(p)$ constante, temos

$$
D_{t}=\sum_{j=1}^{3} P_{O j} C_{o j}(1+p)^{t} \prod_{\tau=1}^{t}\left(1+\eta_{j} \tau^{r} \tau\right)
$$


4.1. Características da Distribuição de Renda no Estado de São Paulo

A distribuição da renda que se utilizou neste estudo corresponde a existente no Estado de São Paulo em 1974.

Para anālise do grau de concentração da renda calculou-se - indice de Gini segundo o método que considera a desigualdade da distribuição dentro dos estratos, evitando assim o problema da subestimação do grau real de concentraçãol3/.

Na Tabela 10 apresentamos 0 indice de concentração da renda no Estado de São Paulo, nas áreas urbanas e rural.

13/ Ver HOFFMANN (1979). 
Tabela 10. Indice de Gini (G) da distribuição da despesa global entre familias no Estado de São Paulo, em 1974, de acordo com os dados do ENDEF. Porcentagem da população e respectiva porcen tagem da despesa global

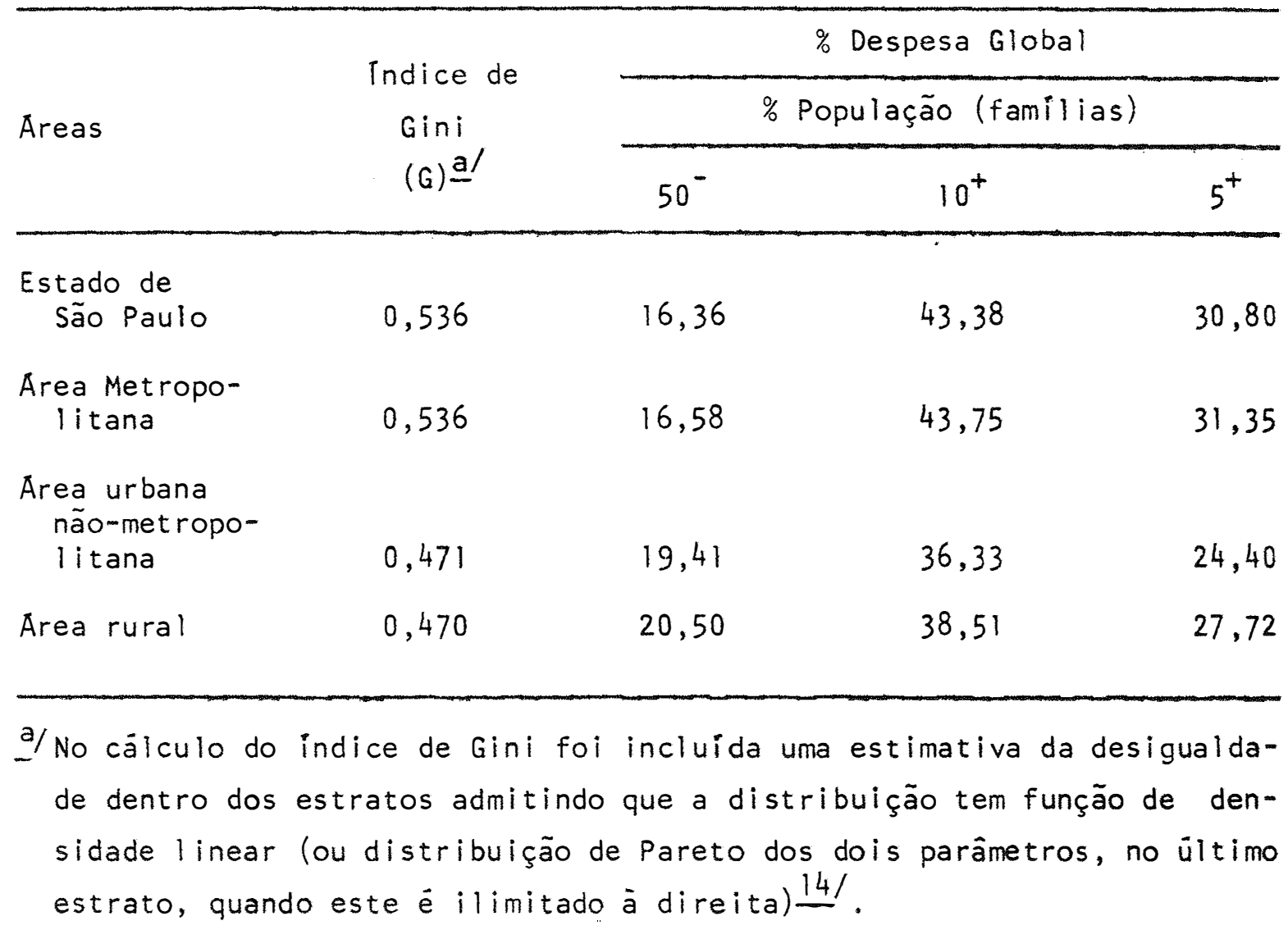

Os resultados indicam uma marcante diferença entre o rural e o urbano, apresentando uma distribuição de renda mais desigual para - setor urbano do que para o rural, confirmando resultados apresentados pela CEPAL (1970), onde afirmam ser este fenômeno consequência do baixo 14/ Idem HOFFMANN (1979). 
nível de renda média rural e da menor diversificação da economia rural.

Comparando os índices, nota-se que o grau de concentração da renda apresenta-se maior para a àrea urbana metropolitana, aparecendo de uma forma menos acentuada para a ärea urbana não-metropolitana.

Os resultados mostram claramente a existência de um processo de concentração da renda mais acentuado nas äreas mais industrial zadas. Esse fato pode ser explicado lembrando que o processo de industrialização do Brasil ter se caracterizado pelo uso de tecnologia capital-intensiva (Ver BRESSER PEREIRA, 1972), o que contribui para aumentar a concentração da distribuição da renda nas äreas industrializadas, em favor da classe capitalista, numa situação de oferta abundante de mãode-obra não-qual ificada.

Comparemos agora os perfis de distribuição de renda apresentados na Tabela 10 e ilustrados na Figura 3 pelas Curvas de Lorenz. Verifica-se que os $50 \%$ mais pobres da população apresentam uma participação percentual na despesa global ou renda muito menor do que a apresen tada pelos $5 \%$ mais ricos da população,

Nos quatro decis subsequentes, os incrementos na participação percentual da despesa global são pequenos. Os ültimos $10 \%$ da popu lação, acima do 9: decil, apresentam uma participação percentual grande, correspondente a quase metade da despesa global ou renda da população.

Essa estrutura de distribuição de renda deverä se refletir na estrutura da demanda de alimentos, ocasionando diferenciação no consumo alimentar entre os estratos de renda considerados. 


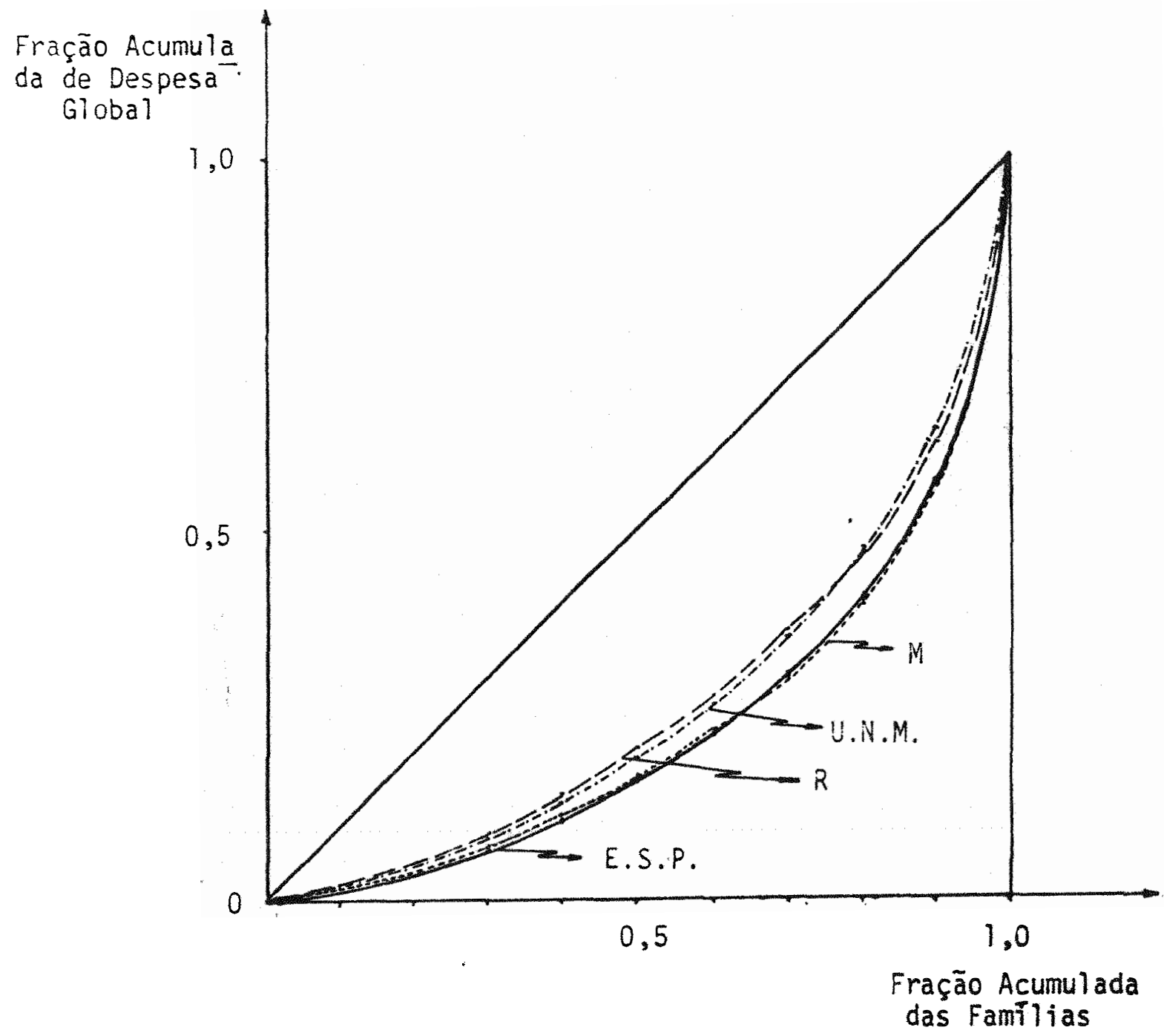

E.S.P. = Estado de São Paulo

$M=$ Metropolitana

U.N.M. = Urbana Não-Metropolitana

$R=$ Rural

Figura 3. Curvas de Lorenz da distribuição da despesa global entre famílias no Estado de São Paulo, em 1974 
Analisando o perfil de distribuição de renda delineado, po de-se considerar que o primeiro grupo, constituído pelos $50 \%$ da população situada no extremo inferior da distribuição, participam do mercado consumindo produtos de primeira necessidade (alimentos, roupa e calçados), tendo pouco acesso aos produtos industriais modernos. A medida, porëm, que passamos para os grupos de renda mais elevada, aumenta a participação destes no mercado de bens de consumo mais sofisticados tecnologicamente, destinados à uma parcela cada vez menor da população (Ver ENDEF, 1974).

4.2. Estimativas dos Coeficientes de Elasticidade-Renda com Base na Função Log-inversa.

Os coeficientes de elasticidade-renda da demanda foram estimados com base na função log-inversa. A vantagem desse método ể a de conduzir a elasticidades diferentes para os diferentes níveis de renda.

No caso dessas estimativas, o valor absoluto da elasticidade necessariamente diminui quando o nivel de renda ou despesa global aumenta.

Comparando os resultados obtidos para as äreas de estudo, observam-se diferenças substanciais nas elasticidades-renda. Os resultados obtidos aparecem nas Tabelas $11,12,13$ e 14.

Os grupos de alimentos ricos em proteinas ("Carnes e Pescados", Ovos - leite e queijos"? apresentam coeficientes de elasticidade elevados, sendo que para o primeiro estrato estes mostram-se frequentemente maiores que 1 , indicando que para os estratos de renda mais baixa 
esses alimentos podem ser considerados "de luxo". Note-se que o mesmo ë observado para as "Frutas".

Os grupos de alimentos energéticos aparecem com elasticidades positivas, porém menores que 1 (bens necessários). A demanda para - grupo das "Leguminosas e oleaginosas" apresenta um coeficiente reduzido para as áreas urbanas e mais elevado para a área rural. O coeficiente do grupo "Legumes e verduras" é relativamente elevado para o lo estrato de renda, em todas as áreas, mostrando valor maior do que 1 apenas para a ärea rural.

Quanto aos coeficientes de elasticidade relativo ao dispên dio em "Alimentação fora do domicillio", estes são indicativos da tendência de substituição parcial da alimentação domiciliar pela consumida fora do domicilio (restaurantes) quando se passa da área rural para a urbana não-metropolitana e desta para a metropolitana. Assim, as áreas urbanas aparecem com coeficientes elevados, enquanto a área rural mostra-se com coeficiente relativamente reduzido.

Note-se, porëm, que a comparação direta entre os coeficien tes das äreas urbanas e a rural deve ser evitada, pois os limites dos estratos são diferentes. Apenas no caso dos parâmetros ( $B$ ) a comparação pode ser realizada. 
Tabela 11. Coeficientes de elasticidade-renda por grupos de alimentos, nos três estratos considerados, para o Estado de São Paulo, obtidos através da função log-inversa

\begin{tabular}{|c|c|c|c|}
\hline \multirow{2}{*}{ Grupos de alimentos } & \multicolumn{3}{|c|}{ Coeficientes de elasticidade } \\
\hline & 19 estrato & $2:$ estrato & $3:$ estrato \\
\hline Despesas correntes & 1,17 & 0.49 & 0,14 \\
\hline Despesas de consumo & 1,13 & 0,48 & 0,14 \\
\hline Alimentação & 0,70 & 0,30 & 0,08 \\
\hline Cereais e derivados & 0,36 & 0,15 & 0,04 \\
\hline Tubërculos, raízes e similares & 0,50 & 0,21 & 0,06 \\
\hline Açücares e derivados & 0,38 & 0,16 & 0,05 \\
\hline Leguminosas e oleaginosas & 0,11 & 0,05 & 0,01 \\
\hline Legumes e verduras & 0,77 & 0,32 & 0,09 \\
\hline Frutas & 1,43 & 0,60 & 0,17 \\
\hline Carnes e pescados & 1,00 & 0,42 & 0,12 \\
\hline Ovos, leite e queijos & 0,93 & 0,39 & 0,11 \\
\hline Oleos e gorduras & 0,35 & 0,15 & 0,04 \\
\hline Bebidas e diversos & 0,53 & 0,22 & 0,06 \\
\hline Alimentação fora do domicí lio & 1,18 & 0,50 & 0,14 \\
\hline
\end{tabular}


Tabela 12. Coeficientes de elasticidade-renda por grupos de alimentos, nos três estratos considerados, para a ärea metropolitana,obtidos atravēs da função log-inversa

Grupos de alimentos

Coeficientes de elasticidade

1\% estrato $2 \%$ estrato $3 \%$ estrato

\begin{tabular}{llll} 
Despesas correntes & 1,30 & 0,61 & 0,16 \\
Despesas de consumo & 1,27 & 0,60 & 0,16 \\
Alimentação & 0,84 & 0,39 & 0,10 \\
Cereais e derivados & 0,43 & 0,20 & 0,05 \\
Tubérculos, raízes e similares & 0,65 & 0,31 & 0,08 \\
Açúcares e derivados & 0,66 & 0,31 & 0,08 \\
Leguminosas e oleaginosas & 0,20 & 0,10 & 0,03 \\
Legumas e verduras & 0,97 & 0,46 & 0,12 \\
Frutas & 1,41 & 0,66 & 0,17 \\
Carnes e pescados & 1,02 & 0,48 & 0,13 \\
Ovos, le ite e queijos & 0,99 & 0,47 & 0,12 \\
Oleos e gorduras & 0,54 & 0,25 & 0,07 \\
Bebidas e diversos & 1,13 & 0,36 & 0,10 \\
Alimentação fora do domicilio & 0,53 & 0,14 \\
\hline
\end{tabular}


Tabela 13. Coeficientes de elasticidade-renda por grupos de alimentos, nos três estratos considerados, para a ārea urbana não-metropolitana, obtidos através da função log-inversa

\begin{tabular}{lccc}
\hline & \multicolumn{3}{c}{ Coeficientes de elasticidade } \\
\cline { 2 - 4 } Grupos de alimentos & 1,09 & 0,46 & 0,16 \\
\hline Despesas correntes & 1,06 & 0,45 & 0,16 \\
Despesas de consumo & 0,71 & 0,30 & 0,11 \\
Alimentação & 0,41 & 0,17 & 0,06 \\
Cereais e derivados & 0,51 & 0,22 & 0,08 \\
Tubërculos, raizes e similares & 0,52 & 0,22 & 0,08 \\
Açücares e derivados & 0,25 & 0,11 & 0,04 \\
Leguminosas e oleaginosas & 0,79 & 0,33 & 0,12 \\
Legumes e verduras & 1,38 & 0,58 & 0,21 \\
Frutas & 1,02 & 0,43 & 0,15 \\
Carnes e pescados & 1,02 & 0,43 & 0,15 \\
Ovos, leite e queijos & 0,40 & 0,17 & 0,06 \\
Oleos e gorduras & 0,56 & 0,24 & 0,08 \\
Bebidas e diversos & 0,93 & 0,39 & 0,14 \\
Alimentação fora do domicilio & & & \\
\hline
\end{tabular}


Tabela 14. Coeficientes de elasticidade-renda por grupos de alimentos, nos três estratos considerados, para a área rural, obtidos atravēs da função log-inversa

\begin{tabular}{|c|c|c|c|}
\hline \multirow{2}{*}{ Grupos de alimentos } & \multicolumn{3}{|c|}{ Coeficientes de elasticidade } \\
\hline & 10 estrato & $2 \%$ estrato & 39 estrato \\
\hline Despesas correntes & 1,16 & 0,53 & 0,17 \\
\hline Despesas de consumo & 1,14 & 0,52 & 0,16 \\
\hline Alimentação & 0,94 & 0,43 & 0,13 \\
\hline Cereais e derivados & 0,88 & 0,40 & 0,13 \\
\hline Tubērculos, raízes e similares & 0,92 & 0,42 & 0,13 \\
\hline Açúcares e derivados & 0,78 & 0,35 & 0,11 \\
\hline Leguminosas e oleaginosas & 0,58 & 0,26 & 0,08 \\
\hline Legumes e verduras & 1,04 & 0,47 & 0,15 \\
\hline Frutas & 2,10 & 0,95 & 0,30 \\
\hline Carnes e pescados & 1,49 & 0,68 & 0,21 \\
\hline Ovos, leite e queijos & 1,34 & 0,61 & 0,19 \\
\hline Oleos e gorduras & 0,82 & 0,37 & 0,12 \\
\hline Bebidas e diversos & 0,76 & 0,34 & 0,11 \\
\hline Alimentação fora do domicílio & 0,40 & 0,18 & 0,06 \\
\hline
\end{tabular}

Quanto aos. coeficientes de determinação, estes apresentam valores altos, geralmente superiores a $90 \%$, e os testes estatisticos são quase sempre significativos. Os resultados se encontram nas Tabelas 15, 16,17 e 18 . 
Para o item "Leguminosas e 0leaginosas" o coeficiente de determinação aparece com valor muito baixo tanto para o Estado de São Pau lo como para a ärea metropolitana $(0,283 ; 0,352)$ e o teste "t" apresenta valores não-significativos (ver Tabelas 15 e 16). Resultado semelhante foi obtido para "Alimentação fora do domicillio" na ärea rural (ver Tabela 18).

Tabela 15. Coeficientes de regressão da função log-inversa por grupos de alimentos, para o Estado de São Paulo

\begin{tabular}{|c|c|c|c|c|}
\hline Grupos de alimentos & a & $b$ & $t=a /$ & $r^{2}$ \\
\hline Despesas correntes & 3,96897 & $-15,61076$ & $-5,968^{* *}$ & 0,836 \\
\hline Despesas de consumo & 3,88037 & $-15,09440$ & $-6,088 * *$ & 0,841 \\
\hline Alimentação & 2,55251 & $-9,34605$ & $-13,111 * *$ & 0,961 \\
\hline Cereais e derivados & 0,69377 & $-4,81804$ & $-7,777^{\star \star}$ & 0,896 \\
\hline $\begin{array}{l}\text { Tubërculos, raízes e } \\
\text { similares }\end{array}$ & $-1,41406$ & $-6,60080$ & $-14,689^{\star \star}$ & 0,969 \\
\hline Açücares e derivados & $-1,15165$ & $-5,10950$ & $-11,334 * *$ & 0,948 \\
\hline Leguminosas e oleaginosas & $-0,76132$ & $-1,47485$ & $-1,661$ & 0,283 \\
\hline Legumes e verduras & $-0,11800$ & $-10,25505$ & $-11,398 * *$ & 0,949 \\
\hline Frutas & $-0,44540$ & $-19,02011$ & $-12,945^{\star \star}$ & 0,960 \\
\hline Carnes e pescados & 1,33853 & $-13,36382$ & $-23,703^{* \star}$ & 0,988 \\
\hline Ovos, leite e queijos & 0,30044 & $-12,38445$ & $-13,112^{* *}$ & 0,961 \\
\hline Oleos e gorduras & $-0,30265$ & $-4,62307$ & $-12,803^{\star \star}$ & 0,959 \\
\hline Bebidas e diversos & $-0,26972$ & $-7,10923$ & $-9,545^{* *}$ & 0,929 \\
\hline $\begin{array}{l}\text { Alimentação fora do } \\
\text { domicillio }\end{array}$ & 0,58205 & $-15,71020$ & $-5,940^{\star \star}$ & 0,834 \\
\hline $\begin{array}{l}\text { a/ Com } 7 \text { graus de liberdad } \\
\text { to utilizando os valore } \\
\text { * Significativo ao nivel } \\
\text { * Significativo ao nivel }\end{array}$ & $\begin{array}{l}5 \% \\
1 \%\end{array}$ & justame & $\begin{array}{l}\text { da função } \\
\text { cap.3). }\end{array}$ & fei- \\
\hline
\end{tabular}


Tabela 16. Coeficientes de regressão da função log-inversa por grupos de alimentos, para a área metropolitana de São Paulo

\begin{tabular}{|c|c|c|c|c|}
\hline Grupos de Alimentos & a & $b$ & $t \underline{a !}$ & $r^{2}$ \\
\hline Despesas correntes & 4,16915 & $-19,52213$ & $-5,412 * \star$ & 0,807 \\
\hline Despesas de consumo & 4,07092 & $-19,00670$ & $-5,569 \star \star$ & 0,816 \\
\hline Alimentação & 2,61711 & $-12,53699$ & $-13,674 * \star$ & 0,964 \\
\hline Cereais e derivados & 0,63776 & $-6,44612$ & $-6,430 * t$ & 0,855 \\
\hline $\begin{array}{l}\text { Tubérculos, raízes e } \\
\text { similares }\end{array}$ & $-1,41610$ & $-9,77034$ & $-13,103 * \star$ & 0,961 \\
\hline Açücares e derivados & $-1,20720$ & $-9,95178$ & $-15,935 * \star$ & 0,973 \\
\hline Leguminosas e oleaginosas & $-0,87835$ & $-3,05907$ & $-1,950$ & 0,352 \\
\hline Legumes e verduras & $-0,03858$ & $-14,54756$ & $-11,039 * \star$ & 0,946 \\
\hline Frutas & $-0,38938$ & $-21,06687$ & $-8,702 * \star$ & 0,915 \\
\hline Carnes e pescados & 1,34517 & $-15,30992$ & $-31,010 * \star$ & 0,993 \\
\hline Ovos, leite e quijos & 0,36975 & $-14,88282$ & $-12,505 * \star$ & 0,957 \\
\hline Oleos e gorduras & $-0,37112$ & $-8,09084$ & $-11,933 * \star$ & 0,953 \\
\hline Bebidas e diversos & $-0,24112$ & $-11,59234$ & $-11,549 \star \star$ & 0,950 \\
\hline $\begin{array}{l}\text { Alimentação fora do } \\
\text { domicillio }\end{array}$ & 0,89173 & $-16,96228$ & $-5,011 * \star$ & 0,782 \\
\hline
\end{tabular}

a/ Com 7 graus de liberdade, uma vez que o ajustamento da função foi fei to utilizando os valores médios para 9 estratos (ver cap. 3).

* Significativo ao nivel de $5 \%$.

** Significativo ao nivel de $1 \%$ 
Tabela 17. Coeficientes de regressão da função log-inversa por grupos de a) imentos, para a ärea urbana não-metropolitana de São Paulo

Grupos de alimentos

a

b

tal

$r^{2}$

Despesas correntes

3,84785

$-14,46501$

$-7,159 * *$

0,880

Despesas de consumo

3,76971

$-14,04264$

$-7,292 * \star$

0,884

Alimentação

2,53581

$-9,36397$

$-13,708 * \star$

0,964

Cereais e derivados

0,72128

$-5,40641$

$-10,308 * *$

0,938

Tubërculos, raízes e similares

$$
-1,35519
$$

$-6,79065$

$-11,613 * *$

0,951

Açücares e derivados

$-0,96384$

$-6,90177$

$-10,203 * \star$

0,937

Leguminosas e oleaginosas

$-0,66089$

$-3,28619$

$-4,923 * *$

0,776

Legumes e verduras

$$
-0,11146
$$

$-10,42755$

$-18,807 * \star$

0,981

Frutas

$-0,49751$

$-18,22953$

$-11,224 * \star$

0,947

Carnes e pescados

1,38072

$-13,45987$

$-15,807^{* *}$

0,973

Ovos, leite e queijos

$$
0,32373
$$

$-13,55107$

$-15,309 * *$

0,971

oleos e gorduras

$-0,21703$

$-5,32023$

$-16,204 * *$

0,974

Bebidas e diversos

$-0,20311$

$-7,38271$

$-8,350 * *$

0,909

Al imentação fora do domi cílio

0,13410

$-12,27459$

$-6,251 * *$

0,848

a/ Com 7 graus de liberdade, uma vez que o ajustamento da função foi feito utilizando os valores médios para 9 estratos (ver cap. 3).

* Significativo ao nivel de $5 \%$.

** Significativo ao nivel de $1 \%$. 
Tabela 18. Coeficientes de regressão da função log-inversa por grupos de alimentos, para a àrea rural de São Paulo

\begin{tabular}{|c|c|c|c|c|}
\hline Grupos de al imentos & $a$ & $b$ & $t \underline{a /}$ & $r^{2}$ \\
\hline Despesas correntes & 3,34153 & $-8,39679$ & $-6,178 * *$ & 0,845 \\
\hline Despesas de consumo & 3,30408 & $-8,23615$ & $-6,414 * \star$ & 0,855 \\
\hline Alimentação & 2,55519 & $-6,80949$ & $-10,123^{\star \star}$ & 0,936 \\
\hline Cereais e derivados & 1,16158 & $-6,36740$ & $-17,180 * \star$ & 0,977 \\
\hline $\begin{array}{l}\text { Tubérculos, raízes e } \\
\text { similares }\end{array}$ & $-1,17093$ & $-6,64324$ & $-8,977^{\star \star}$ & 0,920 \\
\hline Açūcares e derivados & $-0,70417$ & $-5,59620$ & $-23,858 * \star$ & 0,988 \\
\hline Leguminosas e oleaginosas & $-0,09927$ & $-4,15131$ & $-17,144 * *$ & 0,977 \\
\hline Legumes e verduras & $-0,09479$ & $-7,53040$ & $-10,705 * \star$ & 0,942 \\
\hline Frutas & $-0,70750$ & $-15,16405$ & $-8,057 * *$ & 0,903 \\
\hline Carnes e pescados & 1,25763 & $-10,79171$ & $-11,864 * \star$ & 0,953 \\
\hline Ovos, leite e queijos & 0,23113 & $-9,69623$ & $-19,651 * \star$ & 0,982 \\
\hline Oleos e gorduras & 0,21588 & $-5,90577$ & $-10,176 * \star$ & 0,937 \\
\hline Bebidas e diversos & $-0,12216$ & $-5,47608$ & $-8,387^{\star \star}$ & 0,909 \\
\hline $\begin{array}{l}\text { Alimentação fora do } \\
\text { domicillio }\end{array}$ & $-1,36940$ & $-2,91456$ & $-0,914$ & 0,107 \\
\hline
\end{tabular}

a/ Com 7 graus de liberdade, uma vez que o ajustamento da função foi fei to utilizando os valores médios para 9 estratos (ver cap. 3)

* Significativo ao nivel de $5 \%$.

** Significativo ao nível de $1 \%$. 
4.3. Estimativas dos Coeficientes de Elasticidade-Renda com Base na Poligona!

Como observado na metodologia, os coeficientes de elasticidade-renda foram calculados também através do método da poligonal. Permitindo, assim, testar as variações de elasticidade entre os estratos.

Analisando as Tabelas 19, 20, 21 e 22 nota-se a tendência para as elasticidades decrescerem à medida que o nível de renda se eleva. Porém há exceções, como, por exẹplo, o item "Alimentação fora do domicilio" que apresentou, em geral, elasticidades mais baixas para o pri meiro estrato, elevando seus valores para o segundo estrato e reduzindo novamente para o terceiro estrato.

Os grupos das "Frutas", "Carnes e Pescados" e "Ovos-Leite e Queijos" aparecem com elasticidades maiores do que 1 (bens de luxo) no primeiro intervalo, tanto para as äreas urbanas como para a rural, destacando-se o coeficiente para "Frutas" da ärea rural $(2,35)$. A mesma tendência foi observada para "Legumes e Verduras" na ärea rural (ver Tabela 22).

O grupo "Tubérculos, Raízes e Similares", embora apresentando elasticidades decrescentes, não registrou nenhuma variação estatisticamente significativa no valor das elasticidades em três das äreas estudadas. Resultado semelhante foi obtido na ärea rural para os itens "Oleos e gorduras", "Bebidas e diversos" e "Frutas".

De todos os grupos de alimentos analisados, a maioria apre sentou variações significativas entre pelo menos dois dos estratos 
considerados, a um nivel de significância de $5 \%$.

Os resultados obtidos por este método mosțraram-se satisfatórios, apresentando altos valores para os coeficientes de determinação $\left(R^{2}\right)$, sendo o mais baixo encontrado para o item "Alimentação fora do domicilio" na ärea rural $(0,723)$.

Estes resultados vem confirmar a inadequação de se usar elasticidades constantes no cālculo de projeções de demanda, quando o objetivo é obter projeções mais realistas.

Comparando-se os resultados obtidos pelos dois modelos (log-inversa e poligonal) observa-se que os coeficientes de elasticidade apresentam valores relativamente prōximos para grande parte dos grupos de alimentos. Entretanto, as estimativas das elasticidades através do segundo modelo mostram-se na maioria mais elevados, principalmente no 3 ? es trato. Isto certamente ocorre, no estrato de maior renda, devido ao fato de o ajustamento da função log-inversa pressupor que a elasticidaderenda varia inversamente com a renda familiar. Quanto aos coeficientes de determinação, estes apresentam valores altos para ambos os métodos, sendo sempre maiores os obtidos através do ajuste de poligonal. 
Tabela 19. Coeficientes de elasticidade-renda por grupos de alimentos, nos estratos considerados, para o Estado de São Paulo, calculados através do ajustamento de poligonal bilogaritmica; coeficiente de determinação e teste $F$ da regressão

\begin{tabular}{|c|c|c|c|c|c|}
\hline \multirow[b]{2}{*}{ Grupos de alimentos } & \multicolumn{3}{|c|}{ Coeficientes de elasticidade } & \multirow{2}{*}{$R^{2}$} & \multirow[b]{2}{*}{ Teste $F$} \\
\hline & $\begin{array}{c}1 \% \\
\text { estrato }\end{array}$ & $\begin{array}{c}20 \\
\text { estrato }\end{array}$ & $\begin{array}{c}39 \\
\text { estrato }\end{array}$ & & \\
\hline Despesas correntes & 0,96 & 0,83 & $0,69 *$ & 1,000 al & $3517,07^{\star *}$ \\
\hline Despesas de consumo & 0,93 & 0,80 & $0,65 *$ & 1,000 al & $3502,41 * \star$ \\
\hline Alimentação & 0,73 & $0,33 * \star$ & 0,24 & 0,997 & $537,67 * *$ \\
\hline Cereais e derivados & 0,59 & $-0,16 * \star$ & 0,01 & 0,977 & $72,36 * \star$ \\
\hline $\begin{array}{l}\text { Tubérculos, raizes e } \\
\text { similares }\end{array}$ & 0,53 & 0,23 & 0,13 & 0,982 & $91,05 * \star$ \\
\hline Açūcares e derivados & 0,43 & $0,06 \star$ & 0,18 & 0,968 & $49,90 * *$ \\
\hline $\begin{array}{r}\text { Leguminosas e } \\
\text { oleaginosas }\end{array}$ & 0,32 & $-0,31 *$ & $-0,03$ & 0,817 & $7,43 *$ \\
\hline Legumes e verduras & 0,76 & $0,46 *$ & 0,25 & 0,996 & $458,36 * *$ \\
\hline Frutas & 1,47 & $0,74 \star \star$ & 0,45 & 0,997 & $545,20 * *$ \\
\hline Carnes e pescados & 1,13 & $0,42 \star \star$ & 0,20 & 0,997 & $502,96 \star \star$ \\
\hline Ovos, leite e queijos & 0,97 & $0,42 *$ & 0,33 & 0,994 & $269,79 * *$ \\
\hline Oleos e gorduras & 0,50 & $-0,04 * *$ & 0,04 & 0,973 & $59,89 * *$ \\
\hline Bebidas e diversos & 0,48 & 0,50 & $0,07 \star \star$ & 0,998 & $728,29 * *$ \\
\hline $\begin{array}{l}\text { Al imentação fora do } \\
\text { domicilio }\end{array}$ & 0,89 & $1,15 * \star$ & $0,51 \star \star$ & $1,000 \stackrel{a}{a}$ & $16581,97^{\star \star}$ \\
\hline
\end{tabular}

* Indica que a variação do valor da elasticidade em relação ao estrato anterior é estatisticamente significativa ao nivel de $5 \%$.

** Idem ao nivel de $1 \%$.

a/ Por aproximação, isto é, $R^{2}>0,9995$. 
Tabela 20. Coeficientes de elasticidade-renda por grupos de alimentos, nos estratos considerados, para a área metropolitana, calculados através do ajustamento de poligonal bilogarítmica; coe ficiente de determinação e teste $F$ da regressão

\begin{tabular}{|c|c|c|c|c|c|}
\hline \multirow{2}{*}{ Grupos de alimentos } & \multicolumn{3}{|c|}{ Coeficientes de elasticidade } & \multirow{2}{*}{$R^{2}$} & \multirow{2}{*}{ Teste $F$} \\
\hline & $\begin{array}{c}19 \\
\text { estrato }\end{array}$ & $\begin{array}{l}29 \\
\text { estrato }\end{array}$ & $\begin{array}{l}3 ? \\
\text { estrato }\end{array}$ & & \\
\hline Despesas correntes & 0,97 & 0,85 & $0,69 *$ & 0,999 & $2693,91 * \star$ \\
\hline Despesas de consumo & 0,96 & 0,83 & $0,65^{\star}$ & 0,999 & $2605,67 \star \star$ \\
\hline Alimentaçäo & 0,89 & $0,45 \star \star$ & $0,22 \star \star$ & 0,999 & $1121,13 * \star$ \\
\hline Cereais e derivados & 0,78 & $-0,05^{\star \star}$ & 0,00 & 0,982 & $89,13 * \star$ \\
\hline $\begin{array}{l}\text { Tubérculos, raízes e } \\
\text { similares }\end{array}$ & 0,77 & $0,28 *$ & 0,15 & 0,979 & $79,42^{* *}$ \\
\hline Açücares e derivados & 0,82 & $0,18 * \star$ & 0,20 & 0,996 & $416,51 * \star$ \\
\hline $\begin{array}{l}\text { Leguminosas e } \\
\text { oleaginosas }\end{array}$ & 0,62 & $-0,27 * \star$ & $-0,08$ & $0,895^{3}$ & $14,19 * \star$ \\
\hline Legumes e verduras & 0,99 & $0,58 * \star$ & $0,26 \star \star$ & 0,999 & $1316,99 * *$ \\
\hline Frutas & 1,36 & 0,89 & $0,43^{\star}$ & 0,994 & $270,55^{\star \star}$ \\
\hline Carnes e pescados & 1,22 & $0,46 * \star$ & $0,19^{*}$ & 0,996 & $381,33 * \star$ \\
\hline Ovos, leite e queijos & 1,09 & $0,44 \star \star$ & 0,31 & 0,995 & $336,64 * \star$ \\
\hline Oleos e gorduras & 0,80 & $0,11 * *$ & 0,05 & 0,982 & $89,63 * \star$ \\
\hline Bebidas e diversos & 0,77 & 0,65 & $0,05 * \star$ & 0,998 & $881,67^{\star *}$ \\
\hline $\begin{array}{l}\text { Alimentação fora do } \\
\text { domicilio }\end{array}$ & 0,60 & $1,25^{\star}$ & $0,41 \star \star$ & 0,992 & $211,41 * \star$ \\
\hline
\end{tabular}

* Indica que a variação do valor da elasticidade em relação ao estrato anterior é estatisticamente significativa ao nível de $5 \%$.

** Idem ao nivel de $1 \%$. 
Tabela 21. Coeficientes de elasticidade-renda por grupos de alimentos, nos estratos considerados, para a ärea urbana não-metropolita na, calculados atravēs do ajustamento de poligonal bilogaritmica; coeficiente de determinação e teste $F$ da regressão

\begin{tabular}{|c|c|c|c|c|c|}
\hline \multirow[b]{2}{*}{ Grupos de alimentos } & \multicolumn{3}{|c|}{ Coeficientes de elasticidade } & \multirow{2}{*}{$R^{2}$} & \multirow[b]{2}{*}{ Teste $F$} \\
\hline & $\begin{array}{l}19 \\
\text { estrato }\end{array}$ & 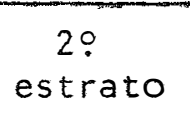 & $\begin{array}{l}39 \\
\text { estrato }\end{array}$ & & \\
\hline Despesas correntes & 0,95 & 0,80 & 0,62 & 0,999 & $1341,68 * *$ \\
\hline Despesas de consumo & 0,93 & 0,77 & 0,59 & 0,999 & $1460,74 * *$ \\
\hline Alimentação & 0,76 & $0,27^{\star \star}$ & 0,30 & 0,997 & $529,27^{* \star}$ \\
\hline Cereais e derivados & 0,60 & $-0,12 \star \star$ & 0,08 & 0,968 & $49,75 * *$ \\
\hline $\begin{array}{l}\text { Tubërculos, raízes e } \\
\text { similares }\end{array}$ & 0,53 & 0,28 & 0,17 & 0,986 & $118,88 * *$ \\
\hline Açúcares e derivados & 0,57 & 0,13 & 0,28 & 0,971 & $56,09 * *$ \\
\hline $\begin{array}{l}\text { Leguminosas e } \\
\text { oleaginosas }\end{array}$ & 0,39 & $-0,18 *$ & 0,11 & 0,839 & $8,70^{*}$ \\
\hline Legumes e verduras & 0,85 & $0,33 * *$ & 0,26 & 0,995 & $322,01^{* *}$ \\
\hline Frutas & 1,43 & $0,75 * \star$ & 0,45 & 0,997 & $544,26 * *$ \\
\hline Carnes e pescados & 1,11 & $0,46 * \star$ & 0,28 & 0,997 & $502,62 * \star$ \\
\hline Ovos, leite e queijos & 1,10 & $0,39 *$ & 0,42 & 0,987 & $123,85^{\star *}$ \\
\hline Oleos e gorduras & 0,52 & $0,03 * *$ & 0,06 & 0,976 & $66,78 * \star$ \\
\hline Bebidas e diversos & 0,51 & 0,45 & $0,19 *$ & 0,996 & $463,39 * \star$ \\
\hline $\begin{array}{l}\text { Alimentação fora do } \\
\text { domicillio }\end{array}$ & 0,86 & $0,43^{*}$ & 0,77 & 0,995 & $319,20 * \star$ \\
\hline
\end{tabular}

* Indica que a variação do valor da elasticidade em relação ao estrato anterior é estatisticamente significativa ao nivel de $5 \%$.

$\star \star$ Idem ao nivel de $1 \%$. 
Tabela 22. Coeficientes de elasticidade-renda por grupos de alimentos, nos estratos considerados, para a ärea rural, calculados atra vës do ajustamento de poligonal bilogarítmica; coeficiente de determinação e teste $F$ da regressão

\begin{tabular}{|c|c|c|c|c|c|}
\hline \multirow[b]{2}{*}{ Grupos de alimentos } & \multicolumn{3}{|c|}{ Coeficientes de elasticidade } & \multirow{2}{*}{$R^{2}$} & \multirow[b]{2}{*}{ Teste F } \\
\hline & $\begin{array}{l}10 \\
\text { estrato }\end{array}$ & $\begin{array}{l}2 \% \\
\text { estrato }\end{array}$ & $\begin{array}{l}3 \circ \\
\text { estrato }\end{array}$ & & \\
\hline Despesas correntes & 1,00 & $0,86 * \star$ & $0,73^{\star \star}$ & 1,000 a/ & $14292,03 * *$ \\
\hline Despesas de consumo & 0,99 & $0,85^{\star \star}$ & $0,68 * \star$ & 1,000 al & $9753,10 * *$ \\
\hline Al imentação & 0,97 & $0,64 *$ & $0,30 *$ & 0,997 & $505,25 * \star$ \\
\hline Cereais e derivados & 1,03 & $0,53^{\star}$ & $0,05^{\star}$ & 0,993 & $248,37 * \star$ \\
\hline $\begin{array}{l}\text { Tubërculos, raízes e } \\
\text { similares }\end{array}$ & 1,08 & 0,36 & 0,32 & 0,946 & $28,95^{\star *}$ \\
\hline Açücares e derivados & 0,98 & $0,25 * \star$ & 0,16 & 0,986 & $116,00 * *$ \\
\hline $\begin{array}{l}\text { Leguminosas e } \\
\text { oleaginosas }\end{array}$ & 0,76 & $0,20 \star *$ & 0,05 & 0,997 & $608,01 * \star$ \\
\hline Legumes e verduras & 1,16 & $0,38 *$ & 0,53 & 0,985 & $113,09 * \star$ \\
\hline Frutas & 2,35 & 1,00 & 0,85 & 0,964 & $44,48 * \star$ \\
\hline Carnes e pescados & 1,57 & $0,97^{\star}$ & $0,44 *$ & 0,997 & $476,83 * \star$ \\
\hline Ovos, leite e queijos & 1,71 & $0,14 \star \star$ & 0,61 & 0,987 & $130,33 * *$ \\
\hline oleos e gorduras & 0,87 & 0,62 & 0,11 & 0,978 & $75,27 * \star$ \\
\hline Bebidas e diversos & 0,72 & 0,58 & 0,28 & 0,990 & $163,77^{* *}$ \\
\hline $\begin{array}{l}\text { Alimentação fora do } \\
\text { domicilio }\end{array}$ & $-0,62$ & 2,10 & 0,31 & 0,723 & 4,34 \\
\hline
\end{tabular}

* Indica que a variação do valor da elasticidade em relação ao estrato anterior é estatisticamente significativa ao nivel de $5 \%$.

** Idem ao nivel de $1 \%$.

a/Por aproximação, isto é, $R^{2}>0,9995$. 


\subsection{Projeções de Demanda}

4.4.1. Distribuição do consumo pelos 3 estratos.

Comparando as projeções de demanda de alimentos, obtidas mediante as diferentes redistribuições de renda simuladas para 1979 e 1984, em relação ao consumo do ano-base (1974), obtém-se uma visão da influência da redistribuição da renda sobre o consumo de alimentos.

Naturalmente, o nivel de dispêndio com cada grupo de produtos difere entre os diferentes estratos de renda e as diferentes redistribuições de renda, podendo ser considerado como um indicativo da estrutura alimentar da população.

Nas tabelas $23,24,25$ e 26 aparecem as participações percentuais nos gastos com os diversos grupos de alimentos estudados, segundo as estratificações realizadas para as äreas urbanas e rural.

Nestas tabelas é importante comparar as participações dos estratos em termos dos seus respectivos números de familias, apresentados anteriormente na tabela 7 .

Assim, verifica-se para o Estado de São Paulo que, enquanto o estrato de baixa renda representa $47 \%$ da população, seu dispêndio em al imentos representa apenas $31,6 \%$ do total gasto em alimentação e o estra to de renda elevada, incluindo apenas $25 \%$ da população, tem um dispêndio que representa $37,1 \%$ do total gasto com alimentos.

Essas comparações, se realizadas para determinados grupos de alimentos, mostram discrepâncias ainda mais acentuadas. 
Tabela 23. Participação relativa dos três grandes estratos no consumo, por grupos de alimentos, para o Estado de São Pauloal

\begin{tabular}{|c|c|c|c|c|c|c|c|c|}
\hline Grupos de Alimentos & Estrato & $\begin{array}{l}1974 \\
\text { BASE }\end{array}$ & $\begin{array}{l}1979 \\
\text { Nula }\end{array}$ & $\begin{array}{l}\text { Redistribu } \\
\text { Média }\end{array}$ & $\begin{array}{l}\text { caāo } \\
\text { Orästica }\end{array}$ & $\begin{array}{l}1984 \\
\text { Nula } \\
\end{array}$ & $\begin{array}{l}\text { Redis tribuição } \\
\text { Meddia }\end{array}$ & Drästica \\
\hline Despesas correntes & $\begin{array}{l}1 \\
2 \\
3\end{array}$ & $\begin{array}{l}19,7 \\
26,0 \\
54,3\end{array}$ & $\begin{array}{l}22,1 \\
26,2 \\
51,8\end{array}$ & $\begin{array}{l}26,0 \\
25,2 \\
48,9\end{array}$ & $\begin{array}{l}29,8 \\
24,1 \\
46,1\end{array}$ & $\begin{array}{l}24,2 \\
26,2 \\
49,5\end{array}$ & $\begin{array}{l}30,0 \\
24,8 \\
45,3\end{array}$ & $\begin{array}{l}34,1 \\
23,7 \\
22,2\end{array}$ \\
\hline Despesas de consumo & $\begin{array}{l}1 \\
2 \\
3\end{array}$ & $\begin{array}{l}20,5 \\
26,6 \\
52,9\end{array}$ & $\begin{array}{l}22,9 \\
26,7 \\
50,4\end{array}$ & $\begin{array}{l}26,7 \\
25,7 \\
47,6\end{array}$ & $\begin{array}{l}30,5 \\
24,6 \\
44,9\end{array}$ & $\begin{array}{l}25,0 \\
26,8 \\
48,3\end{array}$ & $\begin{array}{l}30,7 \\
25,2 \\
44,1\end{array}$ & $\begin{array}{l}34,7 \\
24,1 \\
41,2\end{array}$ \\
\hline Altmentação & $\begin{array}{l}1 \\
2 \\
3\end{array}$ & $\begin{array}{l}31,6 \\
31,3 \\
37,1\end{array}$ & $\begin{array}{l}33,4 \\
31,1 \\
35,5\end{array}$ & $\begin{array}{l}36,4 \\
29,9 \\
33,8\end{array}$ & $\begin{array}{l}39,1 \\
28,7 \\
32,2\end{array}$ & $\begin{array}{l}35,0 \\
30,8 \\
34,2\end{array}$ & $\begin{array}{l}39,1 \\
29,1 \\
31,8\end{array}$ & $\begin{array}{l}41,9 \\
28,0 \\
30,1\end{array}$ \\
\hline Cereais e Derivados & $\begin{array}{l}1 \\
2 \\
3\end{array}$ & $\begin{array}{l}40,9 \\
32,2 \\
26,9\end{array}$ & $\begin{array}{l}41,9 \\
31,9 \\
26,2\end{array}$ & $\begin{array}{l}43,6 \\
31,1 \\
25,3\end{array}$ & $\begin{array}{l}45,1 \\
30,3 \\
24,6\end{array}$ & $\begin{array}{l}42,8 \\
31,7 \\
25,6\end{array}$ & $\begin{array}{l}45,0 \\
30,6 \\
24,4\end{array}$ & $\begin{array}{l}46,5 \\
29,8 \\
23,6\end{array}$ \\
\hline Tubérculos, raizes e simflares & $\begin{array}{l}1 \\
2 \\
3\end{array}$ & $\begin{array}{l}35,9 \\
31,6 \\
32,5\end{array}$ & $\begin{array}{l}37,2 \\
31,3 \\
31,5\end{array}$ & $\begin{array}{l}39,4 \\
30,3 \\
30,2\end{array}$ & $\begin{array}{l}41,4 \\
29,4 \\
29,4\end{array}$ & $\begin{array}{l}38,4 \\
31,1 \\
30,6\end{array}$ & $\begin{array}{l}41,4 \\
29,7 \\
28,9\end{array}$ & $\begin{array}{l}43,4 \\
28,9 \\
27,7\end{array}$ \\
\hline Açūcares e derivados & $\begin{array}{l}1 \\
2 \\
3\end{array}$ & $\begin{array}{l}38,8 \\
29,7 \\
31,4\end{array}$ & $\begin{array}{l}39,9 \\
29,5 \\
30,6\end{array}$ & $\begin{array}{l}41,6 \\
28,7 \\
29,6\end{array}$ & $\begin{array}{l}43,2 \\
28,0 \\
28,7\end{array}$ & $\begin{array}{l}40,8 \\
29,3 \\
29,9\end{array}$ & $\begin{array}{l}43,2 \\
28,3 \\
28,6\end{array}$ & $\begin{array}{l}44,8 \\
27,6 \\
27,6\end{array}$ \\
\hline Leguminosas e oleaginosas & $\begin{array}{l}1 \\
2 \\
3\end{array}$ & $\begin{array}{l}46,5 \\
30,6 \\
22,9\end{array}$ & $\begin{array}{l}46,8 \\
30,5 \\
22,7\end{array}$ & $\begin{array}{l}47,3 \\
30,2 \\
22,5\end{array}$ & $\begin{array}{l}47,8 \\
30,0 \\
22,2\end{array}$ & $\begin{array}{l}47,0 \\
30,4 \\
22,5\end{array}$ & $\begin{array}{l}47,7 \\
30,1 \\
22,2\end{array}$ & $\begin{array}{l}48,2 \\
29,8 \\
22,0\end{array}$ \\
\hline Legumes e verduras & $\begin{array}{l}1 \\
2 \\
3\end{array}$ & $\begin{array}{l}29,9 \\
31,4 \\
38,7\end{array}$ & $\begin{array}{l}31,8 \\
31,1 \\
37,0\end{array}$ & $\begin{array}{l}35,0 \\
29,9 \\
35,1\end{array}$ & $\begin{array}{l}38,0 \\
28,7 \\
33,4\end{array}$ & $\begin{array}{l}33,5 \\
30,9 \\
35,6\end{array}$ & $\begin{array}{l}37,9 \\
29,2 \\
32,9\end{array}$ & $\begin{array}{l}41,0 \\
28,0 \\
31,1\end{array}$ \\
\hline Frutas & $\begin{array}{l}1 \\
2 \\
3\end{array}$ & $\begin{array}{l}19,8 \\
30,4 \\
49,8\end{array}$ & $\begin{array}{l}22,7 \\
30,6 \\
46,8\end{array}$ & $\begin{array}{l}27,5 \\
29,1 \\
43,4\end{array}$ & $\begin{array}{l}32,2 \\
27,5 \\
40,3\end{array}$ & $\begin{array}{l}25,3 \\
30,6 \\
44,1\end{array}$ & $\begin{array}{l}32,4 \\
28,3 \\
39,3\end{array}$ & $\begin{array}{l}37,5 \\
26,7 \\
35,8\end{array}$ \\
\hline Carnes a Pescados & $\begin{array}{l}1 \\
2 \\
3\end{array}$ & $\begin{array}{l}27,3 \\
32,8 \\
39,9\end{array}$ & $\begin{array}{l}29,7 \\
32,6 \\
37,7\end{array}$ & $\begin{array}{l}33,6 \\
31,0 \\
35,3\end{array}$ & $\begin{array}{l}37,4 \\
29,5 \\
33,2\end{array}$ & $\begin{array}{l}31,8 \\
32,3 \\
35,9\end{array}$ & $\begin{array}{l}37,4 \\
30,1 \\
32,5\end{array}$ & $\begin{array}{l}41,2 \\
28,6 \\
30,2\end{array}$ \\
\hline Oyos, leite a queljos & $\begin{array}{l}1 \\
2 \\
3\end{array}$ & $\begin{array}{l}27,6 \\
30,9 \\
41,5\end{array}$ & $\begin{array}{l}29,8 \\
30,7 \\
39,5\end{array}$ & $\begin{array}{l}33,5 \\
29,3 \\
37,2\end{array}$ & $\begin{array}{l}37,0 \\
28,0 \\
35,0\end{array}$ & $\begin{array}{l}31,8 \\
30,5 \\
37,7\end{array}$ & $\begin{array}{l}37,0 \\
28,5 \\
34,4\end{array}$ & $\begin{array}{l}40,6 \\
27,2 \\
32,2\end{array}$ \\
\hline Oleos e gorduras & $\begin{array}{l}1 \\
2 \\
3\end{array}$ & $\begin{array}{l}40,2 \\
32,0 \\
27,8\end{array}$ & $\begin{array}{l}41,1 \\
31,7 \\
27,1\end{array}$ & $\begin{array}{l}42,7 \\
31,0 \\
26,3\end{array}$ & $\begin{array}{l}44,2 \\
30,2 \\
25,6\end{array}$ & $\begin{array}{l}41,9 \\
31,5 \\
26,6\end{array}$ & $\begin{array}{l}44,1 \\
30,5 \\
25,4\end{array}$ & $\begin{array}{l}45,5 \\
29,8 \\
24,7\end{array}$ \\
\hline Bebidas e diversos & $\begin{array}{l}1 \\
2 \\
3\end{array}$ & $\begin{array}{l}34,0 \\
31,3 \\
34,6\end{array}$ & $\begin{array}{l}35,4 \\
31,1 \\
33,5\end{array}$ & $\begin{array}{l}37,8 \\
30,1 \\
32,1\end{array}$ & $\begin{array}{l}39,9 \\
29,1 \\
30,9\end{array}$ & $\begin{array}{l}36,7 \\
30,8 \\
32,5\end{array}$ & $\begin{array}{l}39,9 \\
29,5 \\
30,6\end{array}$ & $\begin{array}{l}42,0 \\
28,6 \\
29,4\end{array}$ \\
\hline A) imentaçāo fora do domicilitio & $\begin{array}{l}1 \\
2 \\
3\end{array}$ & $\begin{array}{l}18,9 \\
27,6 \\
53,5\end{array}$ & $\begin{array}{l}21,2 \\
27,8 \\
50,9\end{array}$ & $\begin{array}{l}25,1 \\
26,8 \\
48,1\end{array}$ & $\begin{array}{l}28,8 \\
25,7 \\
45,5\end{array}$ & $\begin{array}{l}23,3 \\
27,9 \\
48,7\end{array}$ & $\begin{array}{l}29,0 \\
26,4 \\
44,6\end{array}$ & $\begin{array}{l}33,1 \\
25,3 \\
41,6\end{array}$ \\
\hline
\end{tabular}

a/ Ver Tabela $7, p .28$, para a distribuição da população. 
Tabela 24. Participação relativa dos três grandes estratos no consumo, por grupos de alimentos, para a ärea metropolịtanal

\begin{tabular}{|c|c|c|c|c|c|c|}
\hline \multirow{2}{*}{ Grupos de Alimentos } & \multirow{2}{*}{ Estrato } & \multirow{2}{*}{$\begin{array}{l}1974 \\
\text { BASE }\end{array}$} & \multirow{2}{*}{\multicolumn{2}{|c|}{$\begin{array}{l}1979 \text { Redistribuição } \\
\text { Nula Mëdia }\end{array}$}} & \multirow{2}{*}{$\begin{array}{l}1984 \text { tula } \\
\text { tula }\end{array}$} & \multirow{2}{*}{$\begin{array}{c}\text { Redistribuiçãa } \\
\text { Média }\end{array}$} \\
\hline & & & & & & \\
\hline Despesas correntes & $\begin{array}{l}1 \\
2 \\
3\end{array}$ & $\begin{array}{l}12,9 \\
24,0 \\
63,1\end{array}$ & $\begin{array}{l}14,9 \\
24,7 \\
60,4\end{array}$ & $\begin{array}{l}20,1 \\
23,5 \\
56,3\end{array}$ & $\begin{array}{l}16,6 \\
25,2 \\
58,1\end{array}$ & $\begin{array}{l}24,0 \\
23,6 \\
52,3\end{array}$ \\
\hline Despesas de consumo & $\begin{array}{l}1 \\
2 \\
3\end{array}$ & $\begin{array}{l}13,4 \\
24,7 \\
61,8\end{array}$ & $\begin{array}{l}15,3 \\
25,4 \\
59,3\end{array}$ & $\begin{array}{l}20,6 \\
24,2 \\
55,2\end{array}$ & $\begin{array}{l}17,1 \\
25,9 \\
57,0\end{array}$ & $\begin{array}{l}24,5 \\
24,2 \\
51,3\end{array}$ \\
\hline Alimentaçāo & $\begin{array}{l}1 \\
2 \\
3\end{array}$ & $\begin{array}{l}20,7 \\
32,5 \\
46,9\end{array}$ & $\begin{array}{l}22,3 \\
32,7 \\
45,0\end{array}$ & $\begin{array}{l}26,8 \\
31,1 \\
42,2\end{array}$ & $\begin{array}{l}23,7 \\
32,8 \\
43,5\end{array}$ & $\begin{array}{l}29,6 \\
30,7 \\
39,7\end{array}$ \\
\hline Cerea is e derivados & $\begin{array}{l}1 \\
2 \\
3\end{array}$ & $\begin{array}{l}27,8 \\
36,2 \\
35,9\end{array}$ & $\begin{array}{l}28,8 \\
36,2 \\
35,0\end{array}$ & $\begin{array}{l}31,4 \\
35,0 \\
33,6\end{array}$ & $\begin{array}{l}29,6 \\
36,1 \\
34,3\end{array}$ & $\begin{array}{l}33,0 \\
34,6 \\
32,4\end{array}$ \\
\hline Tubérculos, raizes e simflares & $\begin{array}{l}1 \\
2 \\
3\end{array}$ & $\begin{array}{l}23,7 \\
33,4 \\
43,0\end{array}$ & $\begin{array}{l}25,0 \\
33,4 \\
41,5\end{array}$ & $\begin{array}{l}28,8 \\
32,0 \\
39,3\end{array}$ & $\begin{array}{l}26,2 \\
33,5 \\
40,3\end{array}$ & $\begin{array}{l}31,1 \\
31,6 \\
37,3\end{array}$ \\
\hline Açücares e derivados & $\begin{array}{l}1 \\
2 \\
3\end{array}$ & $\begin{array}{l}23,8 \\
32,9 \\
43,2\end{array}$ & $\begin{array}{l}25,3 \\
33,0 \\
41,7\end{array}$ & $\begin{array}{l}29,1 \\
33,5 \\
39,4\end{array}$ & $\begin{array}{l}25,5 \\
33,0 \\
40,5\end{array}$ & $\begin{array}{l}31,4 \\
31,1 \\
37,4\end{array}$ \\
\hline Leguminosas e oleaginosas & $\begin{array}{l}1 \\
2 \\
3\end{array}$ & $\begin{array}{l}31,7 \\
37,4 \\
30,9\end{array}$ & $\begin{array}{l}32,2 \\
37,3 \\
30,5\end{array}$ & $\begin{array}{l}33,5 \\
36,6 \\
29,8\end{array}$ & $\begin{array}{l}32,6 \\
37,2 \\
30,2\end{array}$ & $\begin{array}{l}34,3 \\
36,4 \\
29,3\end{array}$ \\
\hline Legumes e verduras & $\begin{array}{l}1 \\
2 \\
3\end{array}$ & $\begin{array}{l}18,5 \\
32,2 \\
49,3\end{array}$ & $\begin{array}{l}20,3 \\
32,5 \\
47,2\end{array}$ & $\begin{array}{l}25,1 \\
30,8 \\
44,1\end{array}$ & $\begin{array}{l}21,8 \\
32,7 \\
45,5\end{array}$ & $\begin{array}{l}28,3 \\
30,5 \\
41,2\end{array}$ \\
\hline Frutas & $\begin{array}{l}1 \\
2 \\
3\end{array}$ & $\begin{array}{l}13,7 \\
28,1 \\
58,2\end{array}$ & $\begin{array}{l}15,8 \\
28,8 \\
55,4\end{array}$ & $\begin{array}{l}21,8 \\
27,2 \\
51,0\end{array}$ & $\begin{array}{l}17,8 \\
29,4 \\
52,9\end{array}$ & $\begin{array}{l}26,1 \\
27,1 \\
46,8\end{array}$ \\
\hline Carnes e pescados & $\begin{array}{l}1 \\
2 \\
3\end{array}$ & $\begin{array}{l}19,2 \\
33,0 \\
47,8\end{array}$ & $\begin{array}{l}21,1 \\
33,3 \\
45,6\end{array}$ & $\begin{array}{l}26,4 \\
31,4 \\
42,3\end{array}$ & $\begin{array}{l}22,8 \\
33,4 \\
43,8\end{array}$ & $\begin{array}{l}29,8 \\
31,0 \\
39,2\end{array}$ \\
\hline Oros, leite e queijos & $\begin{array}{l}1 \\
2 \\
3\end{array}$ & $\begin{array}{l}19,2 \\
31,1 \\
49,6\end{array}$ & $\begin{array}{l}21,1 \\
31,5 \\
47,5\end{array}$ & $\begin{array}{l}26,2 \\
29,7 \\
44,1\end{array}$ & $\begin{array}{l}32,8 \\
31,6 \\
45,6\end{array}$ & $\begin{array}{l}29,6 \\
29,4 \\
41,1\end{array}$ \\
\hline Oleos e gorduras & $\begin{array}{l}1 \\
2 \\
3\end{array}$ & $\begin{array}{l}25,4 \\
35,9 \\
38,7\end{array}$ & $\begin{array}{l}26,6 \\
35,8 \\
37,6\end{array}$ & $\begin{array}{l}29,8 \\
34,4 \\
35,8\end{array}$ & $\begin{array}{l}27,6 \\
35,8 \\
36,6\end{array}$ & $\begin{array}{l}31,7 \\
34,0 \\
34,2\end{array}$ \\
\hline Bebidas a diversos & $\begin{array}{l}1 \\
2 \\
3\end{array}$ & $\begin{array}{l}21,0 \\
33,8 \\
45,2\end{array}$ & $\begin{array}{l}22,5 \\
34,0 \\
43,5\end{array}$ & $\begin{array}{l}26,7 \\
32,4 \\
41,0\end{array}$ & $\begin{array}{l}23,9 \\
34,0 \\
42,7\end{array}$ & $\begin{array}{l}29,3 \\
32,0 \\
38,7\end{array}$ \\
\hline Alimentação fora do domicfilio & $\begin{array}{l}1 \\
2 \\
3\end{array}$ & $\begin{array}{l}13,9 \\
27,0 \\
59,1\end{array}$ & $\begin{array}{l}15,7 \\
27,6 \\
56,7\end{array}$ & $\begin{array}{l}20,4 \\
26,4 \\
53,2\end{array}$ & $\begin{array}{l}17,2 \\
28,1 \\
54,7\end{array}$ & $\begin{array}{l}23,8 \\
26,4 \\
49,8\end{array}$ \\
\hline
\end{tabular}

a/ Ver Tabela 7, p.28, para a distribuição da população. 
Tabela 25. Participação relativa dos três grandes estratos no consumo, por grupos de alimentos, para a ärea urbana não-metropolitanaal

\begin{tabular}{|c|c|c|c|c|c|c|}
\hline \multirow{2}{*}{ Grupos de Alimentos } & \multirow{2}{*}{ Estrato } & \multirow{2}{*}{$\begin{array}{l}1974 \\
\text { BASE }\end{array}$} & \multicolumn{2}{|c|}{1979 Redistribuição } & \multicolumn{2}{|c|}{1984 Redistribuiçāo } \\
\hline & & & Nula & Média & Nula & Média \\
\hline Despesas correntes & $\begin{array}{l}1 \\
2 \\
3\end{array}$ & $\begin{array}{l}24,4 \\
31,1 \\
44,5\end{array}$ & $\begin{array}{l}26,9 \\
30,9 \\
42,2\end{array}$ & $\begin{array}{l}29,6 \\
30,1 \\
40,3\end{array}$ & $\begin{array}{l}29,0 \\
30,7 \\
40,3\end{array}$ & $\begin{array}{l}33,1 \\
29,5 \\
37,4\end{array}$ \\
\hline Despesas de consumo & $\begin{array}{l}1 \\
2 \\
3\end{array}$ & $\begin{array}{l}25,1 \\
31,4 \\
43,5\end{array}$ & $\begin{array}{l}27,5 \\
31,2 \\
41,3\end{array}$ & $\begin{array}{l}30,2 \\
30,4 \\
39,4\end{array}$ & $\begin{array}{l}29,6 \\
31,0 \\
39,4\end{array}$ & $\begin{array}{l}33,6 \\
29,8 \\
36,6\end{array}$ \\
\hline Alimentação & $\begin{array}{l}1 \\
2 \\
3\end{array}$ & $\begin{array}{l}34,4 \\
33,3 \\
32,3\end{array}$ & $\begin{array}{l}36,2 \\
32,9 \\
30,9\end{array}$ & $\begin{array}{l}38,2 \\
32,0 \\
29,7\end{array}$ & $\begin{array}{l}37,8 \\
32,5 \\
29,7\end{array}$ & $\begin{array}{l}40,7 \\
31,3 \\
28,0\end{array}$ \\
\hline Cereais e derivados & $\begin{array}{l}1 \\
2 \\
3\end{array}$ & $\begin{array}{l}42,6 \\
32,8 \\
24,6\end{array}$ & $\begin{array}{l}43,7 \\
32,5 \\
23,9\end{array}$ & $\begin{array}{l}44,9 \\
31,9 \\
23,3\end{array}$ & $\begin{array}{l}44,6 \\
32,1 \\
23,3\end{array}$ & $\begin{array}{l}46,4 \\
31,3 \\
22,4\end{array}$ \\
\hline Tubérculos, raizes e similares & $\begin{array}{l}1 \\
2 \\
3\end{array}$ & $\begin{array}{l}37,5 \\
33,5 \\
29,1\end{array}$ & $\begin{array}{l}38,8 \\
33,1 \\
28,1\end{array}$ & $\begin{array}{l}40,4 \\
32,4 \\
27,3\end{array}$ & $\begin{array}{l}40,0 \\
32,7 \\
27,3\end{array}$ & $\begin{array}{l}42,2 \\
31,8 \\
26,0\end{array}$ \\
\hline Açücares e derivados & $\begin{array}{l}1 \\
2 \\
3\end{array}$ & $\begin{array}{l}38,2 \\
31,8 \\
29,9\end{array}$ & $\begin{array}{l}39,6 \\
31,5 \\
28,9\end{array}$ & $\begin{array}{l}41,2 \\
30,8 \\
28,0\end{array}$ & $\begin{array}{l}40,8 \\
31,1 \\
28,1\end{array}$ & $\begin{array}{l}43,1 \\
30,2 \\
26,8\end{array}$ \\
\hline Leguminosas e oleaginosas & $\begin{array}{l}1 \\
2 \\
3\end{array}$ & $\begin{array}{l}45,8 \\
31,0 \\
23,3\end{array}$ & $\begin{array}{l}46,5 \\
30,7 \\
22,8\end{array}$ & $\begin{array}{l}47,2 \\
30,3 \\
22,5\end{array}$ & $\begin{array}{l}47,0 \\
30,5 \\
22,5\end{array}$ & $\begin{array}{l}48,1 \\
30,0 \\
21,9\end{array}$ \\
\hline Legumes e verduras & $\begin{array}{l}1 \\
2 \\
3\end{array}$ & $\begin{array}{l}33,2 \\
34,1 \\
32,7\end{array}$ & $\begin{array}{l}35,2 \\
33,6 \\
31,1\end{array}$ & $\begin{array}{l}37,4 \\
32,7 \\
29,9\end{array}$ & $\begin{array}{l}36,9 \\
33,2 \\
29,9\end{array}$ & $\begin{array}{l}40,2 \\
31,9 \\
28,0\end{array}$ \\
\hline Frutas & $\begin{array}{l}1 \\
2 \\
3\end{array}$ & $\begin{array}{l}22,2 \\
35,4 \\
42,4\end{array}$ & $\begin{array}{l}25,0 \\
35,2 \\
39,8\end{array}$ & $\begin{array}{l}28,2 \\
34,2 \\
37,6\end{array}$ & $\begin{array}{l}27,5 \\
34,9 \\
37,5\end{array}$ & $\begin{array}{l}32,5 \\
33,3 \\
34,2\end{array}$ \\
\hline Carnes e pescados & $\begin{array}{l}1 \\
2 \\
3\end{array}$ & $\begin{array}{l}28,9 \\
34,8 \\
36,2\end{array}$ & $\begin{array}{l}31,3 \\
34,4 \\
34,2\end{array}$ & $\begin{array}{l}34,0 \\
33,4 \\
32,6\end{array}$ & $\begin{array}{l}33,5 \\
34,0 \\
32,6\end{array}$ & $\begin{array}{l}37,5 \\
32,4 \\
30,1\end{array}$ \\
\hline Oros, leite e queijos & $\begin{array}{l}1 \\
2 \\
3\end{array}$ & $\begin{array}{l}28,8 \\
34,0 \\
37,3\end{array}$ & $\begin{array}{l}31,2 \\
33,6 \\
35,2\end{array}$ & $\begin{array}{l}33,9 \\
32,6 \\
33,5\end{array}$ & $\begin{array}{l}33,3 \\
33,2 \\
33,5\end{array}$ & $\begin{array}{l}37,4 \\
31,7 \\
31,0\end{array}$ \\
\hline Dleos e gorduras & $\begin{array}{l}1 \\
2 \\
3\end{array}$ & $\begin{array}{l}41,3 \\
33,4 \\
25,3\end{array}$ & $\begin{array}{l}42,4 \\
33,0 \\
24,6\end{array}$ & $\begin{array}{l}43,6 \\
32,4 \\
24,0\end{array}$ & $\begin{array}{l}43,3 \\
32,7 \\
24,0\end{array}$ & $\begin{array}{l}45,1 \\
31,9 \\
23,1\end{array}$ \\
\hline Bebidas e diversos & $\begin{array}{l}1 \\
2 \\
3\end{array}$ & $\begin{array}{l}35,9 \\
32,8 \\
31,4\end{array}$ & $\begin{array}{l}37,3 \\
32,4 \\
30,3\end{array}$ & $\begin{array}{l}38,9 \\
31,7 \\
29,3\end{array}$ & $\begin{array}{l}38,6 \\
32,1 \\
29,4\end{array}$ & $\begin{array}{l}40,9 \\
31,1 \\
28,0\end{array}$ \\
\hline Alimentaçäo fora do domicillio & $\begin{array}{l}1 \\
2 \\
3\end{array}$ & $\begin{array}{l}28,4 \\
29,8 \\
41,8\end{array}$ & $\begin{array}{l}30,7 \\
29,5 \\
39,8\end{array}$ & $\begin{array}{l}33,1 \\
28,8 \\
38,1\end{array}$ & $\begin{array}{l}32,6 \\
29,3 \\
38,1\end{array}$ & $\begin{array}{l}36,3 \\
28,1 \\
35,6\end{array}$ \\
\hline
\end{tabular}

al Ver Tabela 7, p.28, para a distribuição da população. 
Tabela 26. Participação relativa dos três grandes estratos no consumo, por grupos de alimentos, para a ärea ruralal

\begin{tabular}{|c|c|c|c|c|c|c|}
\hline \multirow{2}{*}{ Grupos de Alimentos } & \multirow{2}{*}{ Estrato } & \multirow{2}{*}{$\begin{array}{l}1974 \\
\text { BASE }\end{array}$} & \multirow{2}{*}{$\begin{array}{l}1979 R \\
\text { Nula }\end{array}$} & \multirow{2}{*}{$\begin{array}{c}\text { Redistribuiçáo } \\
\text { Médid }\end{array}$} & \multirow{2}{*}{$\begin{array}{l}1984 R \\
\text { Nula }\end{array}$} & \multirow{2}{*}{$\begin{array}{c}\text { Redistribuiçäo } \\
\text { Média }\end{array}$} \\
\hline & & & & & & \\
\hline Despesas correntes & $\begin{array}{l}1 \\
2 \\
3\end{array}$ & $\begin{array}{l}19,5 \\
34,7 \\
45,8\end{array}$ & $\begin{array}{l}21,7 \\
34,9 \\
43,5\end{array}$ & $\begin{array}{l}24,4 \\
34,1 \\
41,8\end{array}$ & $\begin{array}{l}23,6 \\
34,9 \\
41,5\end{array}$ & $\begin{array}{l}27,7 \\
33,7 \\
38,6\end{array}$ \\
\hline Despesas de consumo & $\begin{array}{l}1 \\
2 \\
3\end{array}$ & $\begin{array}{l}20,0 \\
35,2 \\
44,7\end{array}$ & $\begin{array}{l}22,2 \\
35,4 \\
42,4\end{array}$ & $\begin{array}{l}24,9 \\
34,6 \\
40,6\end{array}$ & $\begin{array}{l}24,1 \\
35,4 \\
40,5\end{array}$ & $\begin{array}{l}28,2 \\
34,1 \\
37,7\end{array}$ \\
\hline Alimentaçào & $\begin{array}{l}1 \\
2 \\
3\end{array}$ & $\begin{array}{l}24,5 \\
41,1 \\
34,4\end{array}$ & $\begin{array}{l}26,4 \\
40,9 \\
32,7\end{array}$ & $\begin{array}{l}28,9 \\
39,8 \\
31,3\end{array}$ & $\begin{array}{r}28,1 \\
40,6 \\
. \quad 31,3\end{array}$ & $\begin{array}{l}31,8 \\
39,1 \\
29,2\end{array}$ \\
\hline Cereais e derivados & $\begin{array}{l}1 \\
2 \\
3\end{array}$ & $\begin{array}{l}26,7 \\
43,4 \\
29,9\end{array}$ & $\begin{array}{l}28,6 \\
43,0 \\
28,4\end{array}$ & $\begin{array}{l}31,0 \\
41,8 \\
27,2\end{array}$ & $\begin{array}{l}30,2 \\
42,6 \\
27,1\end{array}$ & $\begin{array}{l}33,8 \\
40,9 \\
25,3\end{array}$ \\
\hline Tubërculos, raizes e similares & $\begin{array}{l}1 \\
2 \\
3\end{array}$ & $\begin{array}{l}25,2 \\
43,0 \\
31,8\end{array}$ & $\begin{array}{l}27,1 \\
42,7 \\
30,2\end{array}$ & $\begin{array}{l}29,6 \\
41,6 \\
28,9\end{array}$ & $\begin{array}{l}28,8 \\
42,4 \\
28,8\end{array}$ & $\begin{array}{l}32,4 \\
40,7 \\
26,9\end{array}$ \\
\hline Açücares e derivados & $\begin{array}{l}1 \\
2 \\
3\end{array}$ & $\begin{array}{l}29,3 \\
42,0 \\
28,7\end{array}$ & $\begin{array}{l}31,0 \\
41,0 \\
27,4\end{array}$ & $\begin{array}{l}33,2 \\
40,5 \\
26,3\end{array}$ & $\begin{array}{l}32,5 \\
41,2 \\
26,3\end{array}$ & $\begin{array}{l}35,7 \\
39,6 \\
24,7\end{array}$ \\
\hline Leguminosas e oleaginosas & $\begin{array}{l}1 \\
2 \\
3\end{array}$ & $\begin{array}{l}32,5 \\
41,8 \\
25,6\end{array}$ & $\begin{array}{l}33,8 \\
41,5 \\
24,7\end{array}$ & $\begin{array}{l}35,6 \\
40,5 \\
23,9\end{array}$ & $\begin{array}{l}35,0 \\
41,1 \\
23,9\end{array}$ & $\begin{array}{l}37,5 \\
39,8 \\
22,7\end{array}$ \\
\hline Legumes e verduras & $\begin{array}{l}1 \\
2 \\
3\end{array}$ & $\begin{array}{l}24,4 \\
39,5 \\
36,1\end{array}$ & $\begin{array}{l}26,6 \\
39,4 \\
34,1\end{array}$ & $\begin{array}{l}29,3 \\
38,2 \\
32,5\end{array}$ & $\begin{array}{l}28,5 \\
39,1 \\
32,4\end{array}$ & $\begin{array}{l}32,6 \\
37,4 \\
30,0\end{array}$ \\
\hline Erutas & $\begin{array}{l}1 \\
2 \\
3\end{array}$ & $\begin{array}{l}11,3 \\
36,9 \\
51,8\end{array}$ & $\begin{array}{l}13,8 \\
38,0 \\
48,2\end{array}$ & $\begin{array}{l}17,3 \\
37,2 \\
45,4\end{array}$ & $\begin{array}{l}16,4 \\
38,7 \\
45,0\end{array}$ & $\begin{array}{l}22,2 \\
37,3 \\
40,5\end{array}$ \\
\hline Carnes e pescados & $\begin{array}{l}1 \\
2 \\
3\end{array}$ & $\begin{array}{l}17,1 \\
40,7 \\
42,7\end{array}$ & $\begin{array}{l}19,6 \\
47,0 \\
39,4\end{array}$ & $\begin{array}{l}22,8 \\
39,9 \\
37,3\end{array}$ & $\begin{array}{l}11,8 \\
41,7 \\
37,1\end{array}$ & $\begin{array}{l}26,9 \\
39,3 \\
33,8\end{array}$ \\
\hline Oyos, leite e queijos & $\begin{array}{l}1 \\
2 \\
3\end{array}$ & $\begin{array}{l}23,4 \\
39,1 \\
37,5\end{array}$ & $\begin{array}{l}26,2 \\
38,9 \\
35,0\end{array}$ & $\begin{array}{l}29,7 \\
37,5 \\
32,9\end{array}$ & $\begin{array}{l}28,6 \\
38,6 \\
32,8\end{array}$ & $\begin{array}{l}33,9 \\
36,4 \\
29,7\end{array}$ \\
\hline Oleos a gorduras & $\begin{array}{l}1 \\
2 \\
3\end{array}$ & $\begin{array}{l}26,8 \\
42,1 \\
31,2\end{array}$ & $\begin{array}{l}28,5 \\
41,8 \\
29,7\end{array}$ & $\begin{array}{l}30,8 \\
40,7 \\
28,5\end{array}$ & $\begin{array}{l}30,0 \\
41,4 \\
28,5\end{array}$ & $\begin{array}{l}33,3 \\
39,9 \\
25,8\end{array}$ \\
\hline Bebidas e diversos & $\begin{array}{l}1 \\
2 \\
3\end{array}$ & $\begin{array}{l}27,5 \\
40,0 \\
32,6\end{array}$ & $\begin{array}{l}29,1 \\
39,7 \\
31,1\end{array}$ & $\begin{array}{l}31,2 \\
38,8 \\
30,0\end{array}$ & $\begin{array}{l}30,6 \\
39,5 \\
30,0\end{array}$ & $\begin{array}{l}33,7 \\
38,7 \\
28,2\end{array}$ \\
\hline Alimentaçáo fora do domicilio & $\begin{array}{l}1 \\
2 \\
3\end{array}$ & $\begin{array}{l}27,6 \\
32,0 \\
40,3\end{array}$ & $\begin{array}{l}28,6 \\
32,0 \\
39,5\end{array}$ & $\begin{array}{l}29,7 \\
31,6 \\
38,7\end{array}$ & $\begin{array}{l}29,4 \\
31,9 \\
38,7\end{array}$ & $\begin{array}{l}31,0 \\
31,4 \\
37,6\end{array}$ \\
\hline
\end{tabular}

a/ Ver Tabela 7, p.28, para a distribuição da população. 
0 item "Frutas" foi um dos que apresentou variações mais sig nificativas. Enquanto o dispêndio relativo da classe inferior è de $19,8 \%$ do total do estado a classe superior atinge $49,8 \%$.

No caso de "Carnes e Pescados", grupo de alimentos mais significativo no dispêndio total, observa-se uma participação de $27,3 \%$ do primeiro estrato, enquanto o terceiro estrato alcança $39,9 \%$ do total.

Os produtos calóricos apresentam uma distribuição de consumo menos assimétrica. Ou seja, à medida que os rendimentos decrescem há também uma maior participação de alimentos energéticos e consequente redu ção da participação de alimentos proteicos e vitaminicos. Não se pode afirmar, através desses dados, que a população do estrato inferior teriam seus requerimentos calóricos satisfeitos, mas os resultados confirmam a tendência observada por CASTRO (1972) de uma maior diversificação na dieta alimentar nos niveis de renda superiores.

Apōs a redistribuição de renda simulada, observam-se mudanças sensiveis na dieta da população de baixa renda. Note-se, porém, que a distribuição do consumo é alterada mesmo quando não se altera a distribuição da renda.

Assim, na hipótese de redistribuição média de renda, o estrato inferior ( $47 \%$ da população), cujo dispêndio relativo em alimentação era menor que o do estrato superior (com $25 \%$ da população), passa a apresentar, em 1984, um consumo de $39,1 \%$, enquanto o outro consome apenas $31,8 \%$. 
Para "Frutas", a participação do consumo do 1 : estrato apresenta um grande acréscimo, passando de $19,8 \%$ para $32,4 \%$, enquanto a participação do consumo do 3 \% estrato declina de $49,8 \%$ para $39,3 \%$.

Outras diferenças significativas podem ser observadas, particularmente para os grupos de alimentos de maior valor nutricional.

Então, verifica-se uma maior participação de alimentos como leite, frutas, legumes, carnes e verduras no consumo alimentar do estrato mais pobre, ao passo que a de cereais, tubérculos, açücares, leguminosas e óleos tende a aumentar relativamente pouco. Observa-se, assim, uma mudança qualitativa na dieta da população de baixa renda ocasionada pela mu dança na composição da "cesta" de alimentos em favor dos alimentos de maior valor protéico e nutricional.

Apenas no caso de "Frutas" e, principalmente, "Al imentação fora do domicillio" a participação do dispêndio do 3 ? estrato no total continua maior do que a do 1 .

Esta tendência de aumento do peso relativo dos alimentos de maior valor nutricional se acentua consideravelmente com a politica de re distribuição de renda drástica.

Em termos gerais, quando se supõe uma redistribuição de renda, os maiores aumentos no consumo ocorrem para os grupos de alimentos que apresentam elasticidade-renda elevada.

A decomposirção dos dados do Estado de São Paulo por äreas mostra que a participação relativa dos alimentos varia também entre as diferentes áreas. 
Assim, conforme se passa para aglomerados urbanos maiores, isto é, quando se passa da ärea urbana não-metropolitana para a metropoli tana, a participação relativa em gastos com alimentos cai consideravelmen te para o estrato inferior.

Dois fatores são frequentemente apontados como responsäveis por esta tendencial5!. Um se refere ao maior consumismo existente na cidade grande em artigos supérfluos, em prejuizo da alimentação. 0 outro se refere aos altos custos existentes nos grandes centros (habitação, transporte), que reduzem a parte da renda destinada aos alimentos.

Entretanto, atravēs dos dados do ENDEF, verifica-se que cerca de $73 \%$ das despesas de consumo da familia de baixa renda da ärea metropolitana são destinadas aos gastos com alimentação $(35,7 \%)$, habitação (33\%) e transporte $(4,1 \%)$. Ou seja, o grande percentual da renda é utilizado no atendimento dessas necessidades bäsicas, não refletindo uma at tude consumista por parte desta população.

Com relação à àrea urbana não-metropolitana observa-se que, embora $75 \%$ dos dispêndios dessas familias destinem-se, também, a estes três itens, cerca de $42,1 \%$ são gastos com alimentação, $31 \%$ com habitação e somente 1,9\% com transporte. Sendo assim, a melhoria do quadro al imentar do estrato inferior da área metropolitana estaria condicionada à alterações no padrão de distribuição de renda e nos niveis dos preços destes bens.

15/ Ver a esse respeito o trabalho de CAMPINO (1979). 
Considerando a hipōtese de redistribuição média de renda, verifica-se para 1984, para as três àreas, um aumento na participação relativa de todos os grupos de alimentos para o estrato inferior em detrimento do estrato superior.

Os maiores acréscimos no consumo ocorrem para a população de menor renda da àrea urbana metropolitana e da área rural. Ambas as äreas apresentavam um quadro alimentar nitidamente pior para o primeiro estrato. Deve-se ressaltar que o limite superior do lo estrato na ärea rural é igual a apenas 2,5 salärios mínimos, enquanto nas äreas urbanas esse limite é de 5 salärios mínimos.

Por exemplo, no grupo "Legumes e Verduras" a participação do 1. estrato apresenta um acréscimo de $9,8 \%$ e $8,2 \%$ para as áreas metropolitana e rural, enquanto na àrea urbana não-metropolitana ocorre um acrēscimo de $7 \%$.

Para as "Frutas" os acréscimos são de $12,4 \%, 10,9 \%$ e $10,3 \%$ respect ivamente,

4.4.2. A relação entre redistribuição da renda e desigualdade do consumo entre estratos

Considere-se uma população cujas famillias estão distribuidas em $\underline{n}$ estratos de renda, dos mais pobres até os mais ricos. Seja $x_{j}$ a proporção de familias nój-ésimo estrato e seja Yja renda média no estra to. Então, a proporção acumulada da renda até o j-ésimo estrato ë 


$$
\Phi_{j}=\frac{\sum_{h=1}^{j} x_{h}{ }^{{ }} h}{\sum_{h=1}^{n} x_{h}{ }^{Y_{h}}}
$$

0 indice de Gini referente à desigualdade da distribuição da renda entre os estratos dessa população ē dado por

$$
G_{R}=1-\sum_{j=1}^{n} x_{j}\left(\Phi_{j}+\Phi_{j-1}\right),
$$

$\operatorname{com} \Phi_{0}=0$

Analogamente, pode-se calcular um indice de Gini para a desigualdade entre estratos no consumo de um grupo de alimentos. Seja $\mathrm{C}_{\mathbf{j}}$ o dispêndio familiar médio com um grupo de alimentos no j-ësimo estrato. En tão, a proporção acumulada do dispêndio total até o j-ésimo estrato é

$$
\Psi_{j}=\frac{\sum_{h=1}^{j} x_{h} C_{h}}{\sum_{h=1}^{n} x_{h} C_{h}}
$$

0 indice de Gini referente à desigualdade de consumo entre os estratos de renda da população é

$$
G=1-\sum_{j=1}^{n} x_{j}\left(\psi_{j}+\psi_{j-1}\right),
$$

$\operatorname{com} \Psi_{0}=0$ 
Na Tabela 27 estão os valores dos respectivos indices de desigualdade do estado para as três hipóteses de redistribuição da renda.

Comparando o valor do indice de Gini relativo à concentração de renda em 1974, apresentado na Tabela 27, com aquele apresentado na tabela 10, nota-se que os resultados diferem. Isto porque, o indice de Gini deste tópico foi calculado levando em conta os três grandes estratos e não os nove estratos originais do ENDEF. Observe, também, que este valor está subestimado, uma vez que, ao se proceder o cálculo, se admite que a renda seja igualitariamente distribuída dentro de cada estrato.

0 exame do indice de concentração do consumo e sua comparação com o indice de concentração da renda pode contribuir para uma melhor avaliação da influência da distribuição da renda sobre o padrão de consumo.

Para visualizar melhor as modificações que sofreu a distribuição do consumo, no período 1974/84, vamos comparar, graficamente, alguns resultados.

Lembremos que $G_{R}$ representa o indice de concentração da renda e G representa o indice de concentração do consumo. Os pares de valores $\left(G_{R}, G\right)$ definem pontos num sistema de eixos cartesianos ortogonais como ilustram os grāficos da Figura 4. Esses grä́icos mostram a relação entre $G$ e $G_{R}$ no ano de 1984, considerando as três hipóteses sobre redistribuição de renda. 
Tabela 27. Indices de Gini da distribuição do consumo $(G)$ e da renda $\left(G_{R}\right)$ entre familias no Estado de São Paulo, 1974-1984

\begin{tabular}{|c|c|c|c|c|c|c|c|}
\hline \multirow{2}{*}{$\begin{array}{l}\text { Categorias de } \\
\text { despesas }\end{array}$} & \multirow{2}{*}{$\begin{array}{l}1974 \\
\text { Base }\end{array}$} & \multicolumn{3}{|c|}{1979 Redistribuição } & \multirow{2}{*}{$\begin{array}{l}1984 \\
\text { Nula }\end{array}$} & \multicolumn{2}{|c|}{ Redistribuição } \\
\hline & & Nula & Mëdia & $\begin{array}{l}\text { Drás- } \\
\text { tica }\end{array}$ & & Média & $\begin{array}{l}\text { Dräs- } \\
\text { tica }\end{array}$ \\
\hline Renda(despesa global) & 0,45 & 0,45 & 0,40 & 0,33 & 0,45 & 0,35 & 0,22 \\
\hline Despesas correntes & 0,36 & 0,33 & 0,29 & 0,24 & 0,30 & 0,24 & 0,19 \\
\hline Despesas de consumo & 0,35 & 0,32 & 0,27 & 0,21 & 0,29 & 0,23 & 0,18 \\
\hline Al imentação & 0,18 & 0,16 & 0,13 & 0,10 & 0,14 & 0,10 & 0,07 \\
\hline $\begin{array}{l}\text { Tubérculos, raízes } \\
\text { e similares }\end{array}$ & 0,13 & 0,11 & 0,09 & 0,07 & 0,10 & 0,06 & 0,04 \\
\hline Açūcares e derivados & 0,10 & 0,08 & 0,07 & 0,05 & 0,07 & 0,05 & 0,03 \\
\hline Legumes e verduras & 0,20 & 0,18 & 0,15 & 0,11 & 0,16 & 0,11 & 0,08 \\
\hline Frutas & 0,34 & 0,30 & 0,25 & 0,19 & 0,27 & 0,19 & 0,13 \\
\hline Carnes e pescados & 0,23 & 0,20 & 0,16 & 0,12 & 0,17 & 0,12 & 0,07 \\
\hline Ovos, leite e queijos & 0,24 & 0,21 & 0,17 & 0,13 & 0,18 & 0,13 & 0,09 \\
\hline Bebidas e diversos & 0,15 & 0,13 & 0,11 & 0,09 & 0,12 & 0,09 & 0,06 \\
\hline $\begin{array}{l}\text { Alimentação fora do } \\
\text { domicilio }\end{array}$ & 0,36 & 0,33 & 0,30 & 0,25 & 0,31 & 0,24 & 0,19 \\
\hline
\end{tabular}

* Os itens "Cereais e derivados", "Leguminosas e oleaginosas" e "Oleos e gorduras" foram excluidos devido ao fato do consumo familiar médio por estrato não crescer sempre com o nível de renda (ver Tabela 28). 
I - A.7imientação -1984

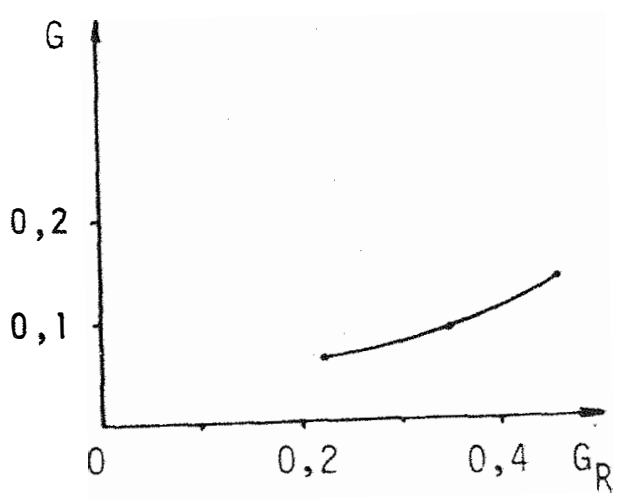

III - Frutas

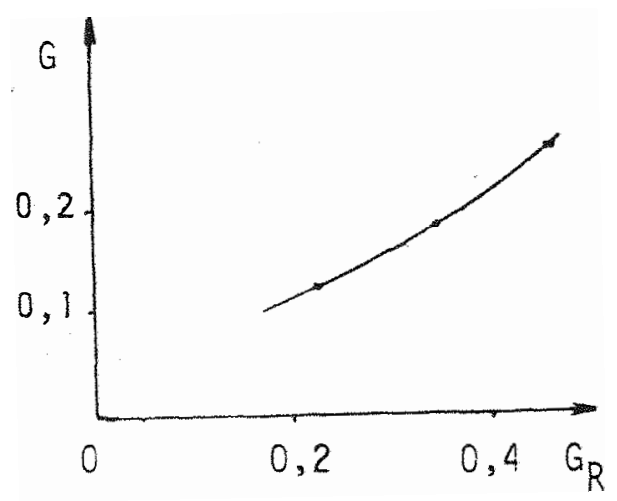

II - Açücares e derivados

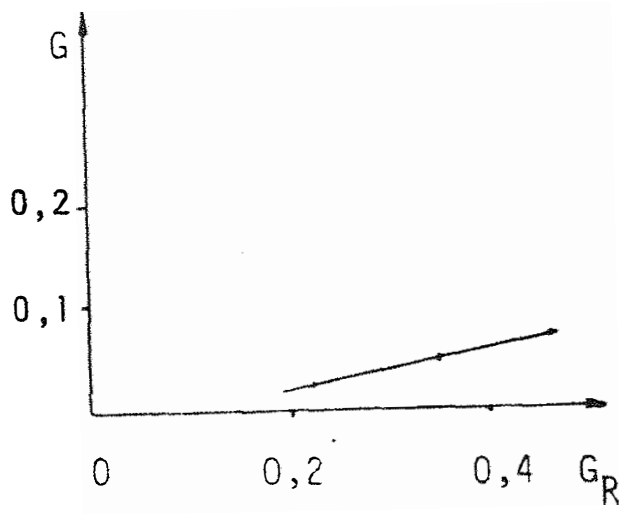

IV - Carnes e pescados

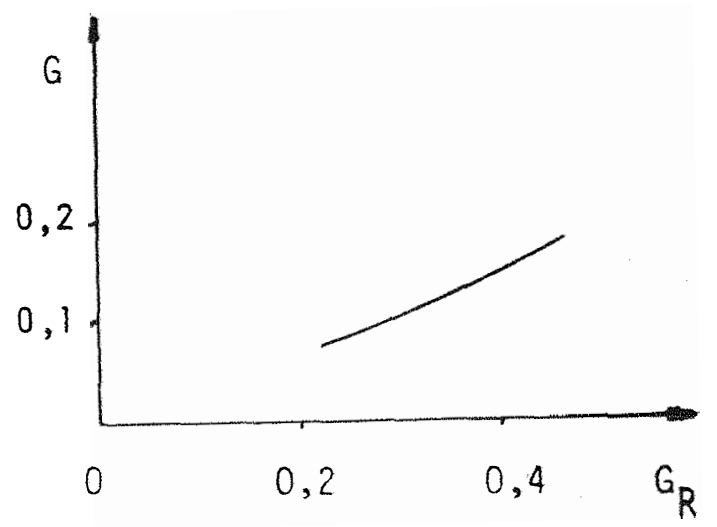

Figura 4. Relação entre os indices de desigualdade da distribuição do consumo e da renda no Estado de São Paulo - 1984 
Com base nesses resultados verifica-se que:

0 indice de Gini para a distribuição do consumo de alimentos no estado decresceu de 0,18 em 1974 para 0,14 em 1984 na hipótese de redistribuição nula, enquanto na hipótese de redistribuição drástica o decréscimo foi mais significativo, obtendo-se um índice de Gini igual a 0,07 .

A distribuição do consumo é menos desigual para produtos calöricos. Observa-se que o indice de Gini para consumo de "Açucares e derivados" em 1974 jā se apresenta bem reduzido $(G=0,10)$.

Em relação aos grupos de alimentos protéicos e vitamínicos, a distribuição do consumo mostra-se mais desigual. Observe que $\circ$ indice de Gini do consumo relativo a "Frutas" é igual a 0,34 em 1974.

Quando se analisa a evolução na desigualdade do consumo fren te às alterações no padrão de distribuição da renda verifica-se que o impacto sobre os grupos de alimentos "nobres" é mais acentuado. 0 indice de consumo para "Açucares e derivados" decresceu de 0,10 a 0,07 na redistribuição nula e de 0,10 a 0,03 na redistribuição drāstica, ao longo dos anos estudados; enquanto o indice para "Frutas", alterou-se, no mesmo periodo, de 0,34 para 0,27 na alternativa de redistribuição nula e de 0,34 para 0,13 na drāstica.

E importante salientar que a distribuição do consumo ê alterada mesmo quando não se altera a distribuição da renda. observe que existe um elemento "uniformizador" na distribuição de gastos em alimentos mesmo com "nenhuma redistribuição", quando a renda familiar média cresce. 
Isso ocorre devido ao fato de a elasticidade-renda, quando positiva, decrescer à medida que passamos para estratos de renda mais alta (de acordo com a função log-inversa).

\subsubsection{Projeções do dispêndio familiar}

Os gastos com alimentação, também foram analisados de um outro ângulo, através do dispêndio familiar anual, para verificar a influência da redistribuição de renda sobre a estrutura de consumo de alimentos.

Pelas Tabelas $28,29,30$ e 31 observa-se, para todas as äreas e grupos de alimentos, que em 1974 (ano-base) o dispêndio familiar anual do 1 ? estrato é muito menor que o do terceiro estrato.

Um confronto entre o 19 e 3 ? estrato das áreas estudadas mostra que, embora variando o valor do dispêndio familiar dos alimentos, hä uma semelhança entre os estratos nos itens de maior peso no dispêndio familiar, sendo que o menor poder aquisitivo do estrato de renda inferior è que estabelece marcantes diferenças nos gastos com estes produtos. Como exemplo, podemos citar o Estado de São Paulo que apresenta entre os 4 itens de maior peso no orçamento alimentar do 19 e do 3 ? estrato os grupos "Carnes e Pescados", "Cereais e Derivados", "Ovos - Leite e Queijos", porēm, com marcantes diferenças nos valores destes dispêndios. Exce to pelo fato de que as populações dos estratos inferiores adquirem produtos menos elaborados $16 /$, esses resultados sugerem ser o problema

16/ Ver a esse respeito CASTRO (1972). 
nutricional mais um problema de natureza quantitativa, ou seja, de quantidades insuficientes de alimentos do que de ineficiente distribuição do or çamento entre os grupos de alimentos.

No Estado de São Paulo, em média, o dispêndio com alimentos no estrato superior $\left(E_{3}\right)$ é 2,24 vezes maior que o do estrato inferior $\left(E_{1}\right)$.

Para determinados grupos de alimentos essas diferenças são mais fortes. Por exemplo, considerando os dispêndios. familiares anuais do 3 ? e do 1 ? estrato, observa-se que $E_{3}$ é 4,78 vezes maior que $E_{1}$ no con sumo de "Frutas", 2,87 vezes maior no consumo de "Ovos-leite e queijos" e 5,38 vezes maior para "Alimentação fora do domicilio".

o primeiro estrato ultrapassa ligeiramente o terceiro estrato somente no grupo de "Leguminosas e 0leaginosas" (1,06 vezes maior). Em todos os outros itens os gastos do terceiro estrato superam os do primei ro.

Após a redistribuição de renda simulada, constata-se que, embora continue a superioridade do dispêndio alimentar do terceiro estrato em relação ao primeiro, as diferenças diminuem sensivelmente.

Deste modo, na hipótese de redistribuição média de renda, tem-se para o terceiro estrato um consumo 2,31 vezes superior em "Frutas", 1,77 vezes em "Ovos-leite e queijos" e 2,93 vezes em "Alimentação fora do domicilio". 
Tabela 28. Dispêndio familiar anual (em milhares de cruzeiros), por grupos de alimentos, para o Estado de São Paulo

\begin{tabular}{|c|c|c|c|c|c|c|c|c|}
\hline \multirow{2}{*}{ Grupos de Alimentos } & \multirow{2}{*}{ Estrato } & \multirow{2}{*}{$\begin{array}{l}1974 \\
\text { BASE }\end{array}$} & \multirow[b]{2}{*}{ Nula } & \multicolumn{2}{|c|}{ Redistribuiço } & \multirow{2}{*}{ Nula } & \multicolumn{2}{|c|}{ Qedistribuicãa } \\
\hline & & & & Mẹdia & Orästica & & Mëdia & Drästica \\
\hline Despesas correntes & $\begin{array}{l}1 \\
2 \\
3\end{array}$ & $\begin{array}{l}12,782 \\
27,745 \\
67,334\end{array}$ & $\begin{array}{l}15,381 \\
30,016 \\
68,969\end{array}$ & $\begin{array}{l}19,010 \\
30,321 \\
68,240\end{array}$ & $\begin{array}{l}22,798 \\
30,321 \\
67,334\end{array}$ & $\begin{array}{l}17,983 \\
32,075 \\
70,189\end{array}$ & $\begin{array}{l}23,986 \\
32,620 \\
69,071\end{array}$ & $\begin{array}{l}28,511 \\
32,620 \\
67,334\end{array}$ \\
\hline Despesas de consumo & $\begin{array}{l}1 \\
2 \\
3\end{array}$ & $\begin{array}{l}12,245 \\
26,093 \\
60,298\end{array}$ & $\begin{array}{l}14,646 \\
28,156 \\
61,627\end{array}$ & $\begin{array}{l}17,982 \\
28,433 \\
61,082\end{array}$ & $\begin{array}{l}21,450 \\
28,433 \\
60,298\end{array}$ & $\begin{array}{l}17,037 \\
30,022 \\
62,769\end{array}$ & $\begin{array}{l}22,519 \\
30,515 \\
61,802\end{array}$ & $\begin{array}{l}26.632 \\
30,515 \\
60,238\end{array}$ \\
\hline Alimentaçào & $\begin{array}{l}1 \\
2 \\
3\end{array}$ & $\begin{array}{r}5,642 \\
9,201 \\
12,617\end{array}$ & $\begin{array}{r}6,308 \\
9,646 \\
12,789\end{array}$ & $\begin{array}{r}7,183 \\
9,705 \\
12,719\end{array}$ & $\begin{array}{r}8,048 \\
9,705 \\
12,617\end{array}$ & $\begin{array}{r}6,931 \\
10,038 \\
12,935\end{array}$ & $\begin{array}{r}8,266 \\
10,140 \\
12,811\end{array}$ & $\begin{array}{r}9,212 \\
10,140 \\
12,617\end{array}$ \\
\hline Cereais e derivados & $\begin{array}{l}1 \\
2 \\
3\end{array}$ & $\begin{array}{l}1,373 \\
1,778 \\
1,719\end{array}$ & $\begin{array}{l}1,454 \\
1,822 \\
1,731\end{array}$ & $\begin{array}{l}1,557 \\
1,828 \\
1,725\end{array}$ & $\begin{array}{l}1,654 \\
1,828 \\
1,719\end{array}$ & $\begin{array}{l}1,527 \\
1,860 \\
1,741\end{array}$ & $\begin{array}{l}1,675 \\
1,870 \\
1,732\end{array}$ & $\begin{array}{l}1,774 \\
1,870 \\
1,719\end{array}$ \\
\hline Tubërculos, raizes e similares & $\begin{array}{l}1 \\
2 \\
3\end{array}$ & $\begin{array}{l}0,135 \\
0,196 \\
0,234\end{array}$ & $\begin{array}{l}0,146 \\
0,203 \\
0,236\end{array}$ & $\begin{array}{l}0,161 \\
0,203 \\
0,235\end{array}$ & $\begin{array}{l}0,174 \\
0,203 \\
0,234\end{array}$ & $\begin{array}{l}0,156 \\
0,208 \\
0,238\end{array}$ & $\begin{array}{l}0,177 \\
0,210 \\
0,236\end{array}$ & $\begin{array}{l}0.192 \\
0.210 \\
0.234\end{array}$ \\
\hline Açücares e derivados & $\begin{array}{l}1 \\
2 \\
3\end{array}$ & $\begin{array}{l}0,203 \\
0,256 \\
0,314\end{array}$ & $\begin{array}{l}0,216 \\
0,263 \\
0,316\end{array}$ & $\begin{array}{l}0,232 \\
0,264 \\
0,315\end{array}$ & $\begin{array}{l}0,247 \\
0,264 \\
0,314\end{array}$ & $\begin{array}{l}0,227 \\
0,269 \\
0,318\end{array}$ & $\begin{array}{l}0,251 \\
0,270 \\
0,316\end{array}$ & $\begin{array}{l}0,267 \\
n, 270 \\
0,314\end{array}$ \\
\hline Leguminosas e oleaginosas & $\begin{array}{l}1 \\
2 \\
3\end{array}$ & $\begin{array}{l}0,430 \\
0,466 \\
0,405\end{array}$ & $\begin{array}{l}0,438 \\
0,470 \\
0,405\end{array}$ & $\begin{array}{l}0,447 \\
0,470 \\
0,405\end{array}$ & $\begin{array}{l}0,456 \\
0,470 \\
0,405\end{array}$ & $\begin{array}{l}0,444 \\
0,473 \\
0,406\end{array}$ & $\begin{array}{l}0,457 \\
0,474 \\
0,406\end{array}$ & $\begin{array}{l}0,466 \\
0,474 \\
0,405\end{array}$ \\
\hline Legumes e verduras & $\begin{array}{l}1 \\
2 \\
3\end{array}$ & $\begin{array}{l}0,358 \\
0,518 \\
0,885\end{array}$ & $\begin{array}{l}0,404 \\
0,651 \\
0,898\end{array}$ & $\begin{array}{l}0,466 \\
0,655 \\
0,893\end{array}$ & $\begin{array}{l}0,528 \\
0,655 \\
0,885\end{array}$ & $\begin{array}{l}0,448 \\
0,680 \\
0,910\end{array}$ & $\begin{array}{l}0,544 \\
0,688 \\
0,900\end{array}$ & $\begin{array}{l}0,612 \\
0,688 \\
0,885\end{array}$ \\
\hline Frutas & $\begin{array}{l}1 \\
2 \\
3\end{array}$ & $\begin{array}{l}0,131 \\
0,330 \\
0,626\end{array}$ & $\begin{array}{l}0,164 \\
0,363 \\
0,644\end{array}$ & $\begin{array}{l}0,211 \\
0,368 \\
0,636\end{array}$ & $\begin{array}{l}0,262 \\
0,368 \\
0,626\end{array}$ & $\begin{array}{l}0,198 \\
0,394 \\
0.659\end{array}$ & $\begin{array}{l}0,280 \\
0,402 \\
0,646\end{array}$ & $\begin{array}{l}0,344 \\
0,402 \\
0,626\end{array}$ \\
\hline Carnes e pescados & $\begin{array}{l}1 \\
2 \\
3\end{array}$ & $\begin{array}{l}1,240 \\
2,458 \\
3,458\end{array}$ & $\begin{array}{l}1,454 \\
2,629 \\
3,526\end{array}$ & $\begin{array}{l}1,745 \\
2,652 \\
3,498\end{array}$ & $\begin{array}{l}2,044 \\
2,652 \\
3,458\end{array}$ & $\begin{array}{l}1,662 \\
2,783 \\
3,584\end{array}$ & $\begin{array}{l}2,131 \\
2,823 \\
3,535\end{array}$ & $\begin{array}{l}2,477 \\
2,823 \\
3,458\end{array}$ \\
\hline Oros, leite e queijos & $\begin{array}{l}1 \\
2 \\
3\end{array}$ & $\begin{array}{l}0,465 \\
0,857 \\
1,335\end{array}$ & $\begin{array}{l}0,538 \\
0,912 \\
1,360\end{array}$ & $\begin{array}{l}0,638 \\
0,920 \\
1,350\end{array}$ & $\begin{array}{l}0,740 \\
0,920 \\
1,335\end{array}$ & $\begin{array}{l}0,610 \\
0,962 \\
1,380\end{array}$ & $\begin{array}{l}0,768 \\
0,975 \\
1,363\end{array}$ & $\begin{array}{l}0,884 \\
0,975 \\
1,335\end{array}$ \\
\hline Oleos a gorduras & $\begin{array}{l}1 \\
2 \\
3\end{array}$ & $\begin{array}{l}0,501 \\
0,658 \\
0,663\end{array}$ & $\begin{array}{l}0,530 \\
0,673 \\
0,667\end{array}$ & $\begin{array}{l}0,566 \\
0,675 \\
0,665\end{array}$ & $\begin{array}{l}0,600 \\
0,675 \\
0,663\end{array}$ & $\begin{array}{l}0,555 \\
0,687 \\
0,671\end{array}$ & $\begin{array}{l}0,607 \\
0,690 \\
0,668\end{array}$ & $\begin{array}{l}0,641 \\
0,690 \\
0,663\end{array}$ \\
\hline Bebldas e diversos & $\begin{array}{l}1 \\
2 \\
3\end{array}$ & $\begin{array}{l}0,396 \\
0,599 \\
0,768\end{array}$ & $\begin{array}{l}0,431 \\
0,621 \\
0,776\end{array}$ & $\begin{array}{l}0,476 \\
0,624 \\
0,773\end{array}$ & $\begin{array}{l}0,520 \\
0,624 \\
0,768\end{array}$ & $\begin{array}{l}0,463 \\
0,640 \\
0,783\end{array}$ & $\begin{array}{l}0,530 \\
0,645 \\
0,777\end{array}$ & $\begin{array}{l}0,576 \\
0,645 \\
0,768\end{array}$ \\
\hline Alimentação fora do domicilio & $\begin{array}{l}1 \\
2 \\
3\end{array}$ & $\begin{array}{r}0,411 \\
0,984 \\
2,211\end{array}$ & $\begin{array}{l}0,495 \\
1,065 \\
2,261\end{array}$ & $\begin{array}{l}0,612 \\
1,076 \\
2,241\end{array}$ & $\begin{array}{l}0,735 \\
1,076 \\
2,211\end{array}$ & $\begin{array}{l}0,579 \\
1,139 \\
2,305\end{array}$ & $\begin{array}{l}0,773 \\
1,158 \\
2,268\end{array}$ & $\begin{array}{l}0,920 \\
1,158 \\
2,211\end{array}$ \\
\hline
\end{tabular}


Tabela 29. Dispêndio familiar anual, (em milhares de cruzeiros), por grü pos de alimentos, para a ärea metropolitana

\begin{tabular}{|c|c|c|c|c|c|c|}
\hline Grupos de Alimentos & Estrato & $\begin{array}{l}1974 \\
\text { BASE }\end{array}$ & $\begin{array}{l}1979 \text { Red } \\
\text { Nula }\end{array}$ & $\begin{array}{c}\text { Redistribuição } \\
\text { Media }\end{array}$ & $\begin{array}{c}1984 \quad R \\
\text { Nula }\end{array}$ & $\begin{array}{c}\text { Redistribuição } \\
\text { Média }\end{array}$ \\
\hline Despesas correntes & $\begin{array}{l}1 \\
2 \\
3\end{array}$ & $\begin{array}{l}14,460 \\
28,539 \\
73,281\end{array}$ & $\begin{array}{l}17,753 \\
31,455 \\
75,193\end{array}$ & $\begin{array}{l}25,553 \\
31,849 \\
74,408\end{array}$ & $\begin{array}{l}21,112 \\
34,144 \\
76,841\end{array}$ & $\begin{array}{l}33,285 \\
34,862 \\
75,445\end{array}$ \\
\hline Despesas de consumo & $\begin{array}{l}1 \\
2 \\
3\end{array}$ & $\begin{array}{l}13,620 \\
26,673 \\
65,180\end{array}$ & $\begin{array}{l}16,633 \\
29,323 \\
66,835\end{array}$ & $\begin{array}{l}23,730 \\
29,681 \\
66,156\end{array}$ & $\begin{array}{l}19,692 \\
31,762 \\
68,261\end{array}$ & $\begin{array}{l}30,701 \\
32,412 \\
67,053\end{array}$ \\
\hline Alimentaçāo & $\begin{array}{l}1 \\
2 \\
3\end{array}$ & $\begin{array}{r}5,339 \\
8,943 \\
12,599\end{array}$ & $\begin{array}{l}6,097 \\
9,521 \\
12,809\end{array}$ & $\begin{array}{lr}7 & 7,757 \\
1 & 9,598 \\
09 & 12,723\end{array}$ & $\begin{array}{r}6,820 \\
10,038 \\
12,989\end{array}$ & $\begin{array}{r}9,207 \\
10,174 \\
12,837\end{array}$ \\
\hline Ceraa is derivados & $\begin{array}{l}1 \\
2 \\
3\end{array}$ & $\begin{array}{l}1,201 \\
1,667 \\
1,615\end{array}$ & $\begin{array}{l}1,286 \\
1,722 \\
1,629\end{array}$ & $\begin{array}{l}1,460 \\
1,729 \\
1,623\end{array}$ & $\begin{array}{l}1,363 \\
1,770 \\
1,641\end{array}$ & $\begin{array}{l}1,596 \\
1,782 \\
1,631\end{array}$ \\
\hline Tubérculos, raizes e similares & $\begin{array}{l}1 \\
2 \\
3\end{array}$ & $\begin{array}{l}0,117 \\
0,177 \\
0,222\end{array}$ & $\begin{array}{l}0,130 \\
0,185 \\
0,2.5\end{array}$ & $\begin{array}{l}0,158 \\
0,187 \\
0,224\end{array}$ & $\begin{array}{l}0,142 \\
0,193 \\
0,227\end{array}$ & $\begin{array}{l}0,180 \\
0,195 \\
0,225\end{array}$ \\
\hline Açücares e derivados & $\begin{array}{l}1 \\
2 \\
3\end{array}$ & $\begin{array}{l}0,145 \\
0,213 \\
0,273\end{array}$ & $\begin{array}{l}0,161 \\
0,224 \\
0,277\end{array}$ & $\begin{array}{l}0,195 \\
0,226 \\
0,276\end{array}$ & $\begin{array}{l}0,176 \\
0,234 \\
0,280\end{array}$ & $\begin{array}{l}0,224 \\
0,236 \\
0,277\end{array}$ \\
\hline Leguminosas e oleaginosas & $\begin{array}{l}1 \\
2 \\
3\end{array}$ & $\begin{array}{l}0,342 \\
0,429 \\
0,347\end{array}$ & $\begin{array}{l}0,353 \\
0,436 \\
0,348\end{array}$ & $\begin{array}{l}0,375 \\
0,437 \\
0,348\end{array}$ & $\begin{array}{l}0,363 \\
0,442 \\
0,349\end{array}$ & $\begin{array}{l}0,392 \\
0,443 \\
0,348\end{array}$ \\
\hline Legumes e verduras & $\begin{array}{l}1 \\
2 \\
3\end{array}$ & $\begin{array}{l}0,319 \\
0,591 \\
0,885\end{array}$ & $\begin{array}{l}0,372 \\
0,635 \\
0,902\end{array}$ & $\begin{array}{l}0,490 \\
0,641 \\
0,895\end{array}$ & $\begin{array}{l}0,423 \\
0,676 \\
0,917\end{array}$ & $\begin{array}{l}0,598 \\
0,686 \\
0,904\end{array}$ \\
\hline Frutas & $\begin{array}{l}1 \\
2 \\
3\end{array}$ & $\begin{array}{l}0,145 \\
0,316 \\
0,640\end{array}$ & $\begin{array}{l}0,180 \\
0,350 \\
0,658\end{array}$ & $\begin{array}{l}0,267 \\
0,355 \\
0,650\end{array}$ & $\begin{array}{l}0,218 \\
0,383 \\
0,673\end{array}$ & $\begin{array}{l}0,355 \\
0,392 \\
0,660\end{array}$ \\
\hline Carnes pescados & $\begin{array}{l}1 \\
2 \\
3\end{array}$ & $\begin{array}{l}1,275 \\
2,332 \\
3,304\end{array}$ & $\begin{array}{l}1,499 \\
2,517 \\
3,372\end{array}$ & $\begin{array}{l}2,004 \\
2,542 \\
3,344\end{array}$ & $\begin{array}{l}1,718 \\
2,684 \\
3,430\end{array}$ & $\begin{array}{l}2,469 \\
2,729 \\
3,381\end{array}$ \\
\hline Ovos, leite e queijos & $\begin{array}{l}1 \\
2 \\
3\end{array}$ & $\begin{array}{l}0,493 \\
0,850 \\
1,324\end{array}$ & $\begin{array}{l}0,577 \\
0,916 \\
1,350\end{array}$ & $\begin{array}{l}0,765 \\
0,925 \\
1,339\end{array}$ & $\begin{array}{l}0,658 \\
0,975 \\
1,372\end{array}$ & $\begin{array}{l}0,937 \\
0,991 \\
1,353\end{array}$ \\
\hline Oleos e gorduras & $\begin{array}{l}1 \\
2 \\
3\end{array}$ & $\begin{array}{l}0,378 \\
0,568 \\
0,599\end{array}$ & $\begin{array}{l}0,412 \\
0,591 \\
0,605\end{array}$ & $\begin{array}{l}0,483 \\
0,594 \\
0,603\end{array}$ & $\begin{array}{l}0,443 \\
0,612 \\
0,611\end{array}$ & $\begin{array}{l}0,540 \\
0,617 \\
0,606\end{array}$ \\
\hline Bebidas e diversos & $\begin{array}{l}1 \\
2 \\
3\end{array}$ & $\begin{array}{l}0,320 \\
0,548 \\
0,716\end{array}$ & $\begin{array}{l}0,362 \\
0,581 \\
0,727\end{array}$ & $\begin{array}{l}0,453 \\
0,586 \\
0,723\end{array}$ & $\begin{array}{l}0,402 \\
0,610 \\
0,737\end{array}$ & $\begin{array}{l}0,531 \\
0,618 \\
0,729\end{array}$ \\
\hline Alimentação fora do domicilio & $\begin{array}{l}1 \\
2 \\
3\end{array}$. & $\begin{array}{l}0,606 \\
1,252 \\
2,674\end{array}$ & $\begin{array}{l}0,725 \\
1,362 \\
2,735\end{array}$ & $\begin{array}{l}0,998 \\
1,377 \\
2,710\end{array}$ & $\begin{array}{l}0,843 \\
1,463 \\
2,787\end{array}$ & $\begin{array}{l}1,257 \\
1,490 \\
2,743\end{array}$ \\
\hline
\end{tabular}


Tabela 30. Dispêndio familiar anual (em milhares de cruzeiros), por grupos de al imentos, para a área urbana não-metropolitana

\begin{tabular}{|c|c|c|c|c|c|c|}
\hline \multirow{2}{*}{ Grupos de Alimentos } & \multirow{2}{*}{ Estrato } & \multirow{2}{*}{$\begin{array}{l}1974 \\
\text { BASE }\end{array}$} & \multirow{2}{*}{\multicolumn{2}{|c|}{$\begin{array}{l}1979 \text { Redistribuição } \\
\text { Nula Média }\end{array}$}} & \multicolumn{2}{|c|}{1984 Redistribuiçāo } \\
\hline & & & & & Nula & Médio \\
\hline Despesas correntes & $\begin{array}{l}1 \\
2 \\
3\end{array}$ & $\begin{array}{l}12,714 \\
27,011 \\
54,467\end{array}$ & $\begin{array}{l}15,109 \\
29,080 \\
55,912\end{array}$ & $\begin{array}{l}17,223 \\
29,356 \\
55,319\end{array}$ & $\begin{array}{l}17,478 \\
30,946 \\
57,160\end{array}$ & $\begin{array}{l}21,086 \\
31,439 \\
56,103\end{array}$ \\
\hline Despesas de consumo & $\begin{array}{l}1 \\
2 \\
3\end{array}$ & $\begin{array}{l}12,204 \\
25,487 \\
49,686\end{array}$ & $\begin{array}{l}14,431 \\
27,380 \\
50,965\end{array}$ & $\begin{array}{l}16,390 \\
27,633 \\
50,440\end{array}$ & $\begin{array}{l}16,624 \\
29,085 \\
52,069\end{array}$ & $\begin{array}{l}19,951 \\
29,535 \\
51,134\end{array}$ \\
\hline Alimentação & $\begin{array}{l}1 \\
2 \\
3\end{array}$ & $\begin{array}{r}5,581 \\
9,036 \\
12,319\end{array}$ & $\begin{array}{r}8,244 \\
9,479 \\
12,530\end{array}$ & $\begin{array}{r}6,807 \\
9,538 \\
12,443\end{array}$ & $\begin{array}{r}6,865 \\
9,859 \\
12,710\end{array}$ & $\begin{array}{r}7,767 \\
9,971 \\
12,557\end{array}$ \\
\hline Cereais e derivados & $\begin{array}{l}1 \\
2 \\
3\end{array}$ & $\begin{array}{l}1,336 \\
1,724 \\
1,818\end{array}$ & $\begin{array}{l}1,426 \\
1,773 \\
1,835\end{array}$ & $\begin{array}{l}1,500 \\
1,779 \\
1,828\end{array}$ & $\begin{array}{l}1,506 \\
1,815 \\
1,851\end{array}$ & $\begin{array}{l}1,619 \\
1,826 \\
1,838\end{array}$ \\
\hline Tubērculos, raizes e simflares & $\begin{array}{l}1 \\
2 \\
3\end{array}$ & $\begin{array}{l}0,139 \\
0,207 \\
0,253\end{array}$ & $\begin{array}{l}0,151 \\
0,214 \\
0,256\end{array}$ & $\begin{array}{l}0,160 \\
0,215 \\
0,255\end{array}$ & $\begin{array}{l}0,161 \\
0,221 \\
0,259\end{array}$ & $\begin{array}{l}0,177 \\
0,222 \\
0,257\end{array}$ \\
\hline Açücares a derivados & $\begin{array}{l}1 \\
2 \\
3\end{array}$ & $\begin{array}{l}0,208 \\
0,290 \\
0,384\end{array}$ & $\begin{array}{l}0,226 \\
0,301 \\
0,389\end{array}$ & $\begin{array}{l}0,241 \\
0,302 \\
0,387\end{array}$ & $\begin{array}{l}0,243 \\
0,310 \\
0,393\end{array}$ & $\begin{array}{l}0,266 \\
0,312 \\
0,389\end{array}$ \\
\hline Leguminosas e oleaginosas & $\begin{array}{l}1 \\
2 \\
3\end{array}$ & $\begin{array}{l}0,401 \\
0,454 \\
0,481\end{array}$ & $\begin{array}{l}0,418 \\
0,462 \\
0,483\end{array}$ & $\begin{array}{l}0,431 \\
0,463 \\
0,482\end{array}$ & $\begin{array}{l}0,432 \\
0,468 \\
0,486\end{array}$ & $\begin{array}{l}0,451 \\
0,470 \\
0,484\end{array}$ \\
\hline Legumes e verduras & $\begin{array}{l}1 \\
2 \\
3\end{array}$ & $\begin{array}{l}0,364 \\
0,626 \\
0,844\end{array}$ & $\begin{array}{l}0,413 \\
0,660 \\
0,860\end{array}$ & $\begin{array}{l}0,454 \\
0,664 \\
0,853\end{array}$ & $\begin{array}{l}0,459 \\
0,690 \\
0,874\end{array}$ & $\begin{array}{l}0,526 \\
0,698 \\
0,862\end{array}$ \\
\hline Frutas & $\begin{array}{l}1 \\
2 \\
3\end{array}$ & $\begin{array}{l}0,128 \\
0,342 \\
0,577\end{array}$ & $\begin{array}{l}0,159 \\
0,375 \\
0,596\end{array}$ & $\begin{array}{l}0,187 \\
0,380 \\
0,588\end{array}$ & $\begin{array}{l}0,191 \\
0,406 \\
0,613\end{array}$ & $\begin{array}{l}0,242 \\
0,414 \\
0,599\end{array}$ \\
\hline Carnes e pescados & $\begin{array}{l}1 \\
2 \\
3\end{array}$ & $\begin{array}{l}1,259 \\
2,535 \\
3,709\end{array}$ & $\begin{array}{l}1,479 \\
2,715 \\
3,801\end{array}$ & $\begin{array}{l}1,671 \\
2,740 \\
3,763\end{array}$ & $\begin{array}{l}1,694 \\
2,877 \\
3,880\end{array}$ & $\begin{array}{l}2,018 \\
2,920 \\
3,813\end{array}$ \\
\hline Ovos, leite e queijos & $\begin{array}{l}1 \\
2 \\
3\end{array}$ & $\begin{array}{l}0,434 \\
0,858 \\
1,324\end{array}$ & $\begin{array}{l}0,511 \\
0,920 \\
1,357\end{array}$ & $\begin{array}{l}0,578 \\
0,928 \\
1,343\end{array}$ & $\begin{array}{l}0,586 \\
0,975 \\
1,385\end{array}$ & $\begin{array}{l}0,698 \\
0,989 \\
1,361\end{array}$ \\
\hline Oleos e gorduras & $\begin{array}{l}1 \\
2 \\
3\end{array}$ & $\begin{array}{l}0,510 \\
0,688 \\
0,734\end{array}$ & $\begin{array}{l}0,543 \\
0,708 \\
0,741\end{array}$ & $\begin{array}{l}0,571 \\
0,710 \\
0,738\end{array}$ & $\begin{array}{l}0,573 \\
0,724 \\
0,747\end{array}$ & $\begin{array}{l}0,616 \\
0,728 \\
0,742\end{array}$ \\
\hline Bebidas e diversos & $\begin{array}{l}1 \\
2 \\
3\end{array}$ & $\begin{array}{l}0,411 \\
0,628 \\
0,846\end{array}$ & $\begin{array}{l}0,449 \\
0,652 \\
0,857\end{array}$ & $\begin{array}{l}0,481 \\
0,655 \\
0,853\end{array}$ & $\begin{array}{l}0,484 \\
0,673 \\
0,867\end{array}$ & $\begin{array}{l}0,534 \\
0,679 \\
0,859\end{array}$ \\
\hline Alimentação fora do domicflio & $\begin{array}{r}1 \\
\cdots \quad \\
3\end{array}$ & $\begin{array}{l}0,390 \\
0,683 \\
1,350\end{array}$ & $\begin{array}{l}0,452 \\
0,728 \\
1,380\end{array}$ & $\begin{array}{l}0,505 \\
0,733 \\
1,367\end{array}$ & $\begin{array}{l}0,511 \\
0,767 \\
1,406\end{array}$ & $\begin{array}{l}0,800 \\
0,777 \\
1,384\end{array}$ \\
\hline
\end{tabular}


Tabela 31. Dispêndio familiar anual (em milhares de cruzeiros), por grupos dealimentos, para a àrea rural

\begin{tabular}{|c|c|c|c|c|c|c|}
\hline \multirow{2}{*}{ irupos de Alinen:0: } & \multirow{2}{*}{ Estrato } & \multirow{2}{*}{$\begin{array}{l}1974 \\
\text { BASE }\end{array}$} & \multirow{2}{*}{$\begin{array}{l}1979 \\
\text { Nuld }\end{array}$} & \multirow{2}{*}{$\begin{array}{c}\text { Redistribuiçào } \\
\text { Média }\end{array}$} & \multicolumn{2}{|c|}{ 1984. Redistribuiçào } \\
\hline & & & & & Nula & Média’ \\
\hline Despesas correntes & $\begin{array}{l}1 \\
2 \\
3\end{array}$ & $\begin{array}{r}7,061 \\
14,938 \\
35,595\end{array}$ & $\begin{array}{r}8,483 \\
16,250 \\
36,557\end{array}$ & $\begin{array}{r}9,879 \\
16,426 \\
36,162\end{array}$ & $\begin{array}{r}9.906 \\
17.445 \\
37.388\end{array}$ & $\begin{array}{l}12,291 \\
17,762 \\
36,684\end{array}$ \\
\hline Despesas de consumo & $\begin{array}{l}1 \\
2 \\
3\end{array}$ & $\begin{array}{r}6,992 \\
14.644 \\
33.503\end{array}$ & $\begin{array}{r}8,371 \\
15,905 \\
34,391\end{array}$ & $\begin{array}{r}9,722 \\
16,074 \\
34,027\end{array}$ & $\begin{array}{r}9,746 \\
17,052 \\
35,158\end{array}$ & $\begin{array}{l}12,046 \\
17,356 \\
34,508\end{array}$ \\
\hline Alimentaçäo & $\begin{array}{l}1 \\
2 \\
3\end{array}$ & $\begin{array}{r}4,209 \\
8,408 \\
12,710\end{array}$ & $\begin{array}{r}4,887 \\
9,003 \\
12,989\end{array}$ & $\begin{array}{r}5,537 \\
9,083 \\
12,875\end{array}$ & $\begin{array}{r}5,544 \\
9,537 \\
13,228\end{array}$ & $\begin{array}{r}6,614 \\
9,678 \\
13,025\end{array}$ \\
\hline Cerea is e derivados & $\begin{array}{l}1 \\
2 \\
3\end{array}$ & $\begin{array}{l}1,158 \\
2,237 \\
2,781\end{array}$ & $\begin{array}{l}1,331 \\
2,385 \\
2,838\end{array}$ & $\begin{array}{l}1,497 \\
2,404 \\
2,815\end{array}$ & $\begin{array}{l}1,498 \\
2,517 \\
2,887\end{array}$ & $\begin{array}{l}1,768 \\
2,551 \\
2,845\end{array}$ \\
\hline Tubërculos, raizes e similares & $\begin{array}{l}1 \\
2 \\
3\end{array}$ & $\begin{array}{l}0,105 \\
0,213 \\
0,284\end{array}$ & $\begin{array}{l}0,122 \\
0,228 \\
0,291\end{array}$ & $\begin{array}{l}0,138 \\
0,230 \\
0,288\end{array}$ & $\begin{array}{l}0,138 \\
0,241 \\
0,296\end{array}$ & $\begin{array}{l}0,164 \\
0,245 \\
0,291\end{array}$ \\
\hline Açúcares e derivados & $\begin{array}{l}1 \\
2 \\
3\end{array}$ & $\begin{array}{l}0,207 \\
0,353 \\
0,436\end{array}$ & $\begin{array}{l}0,234 \\
0,374 \\
0,444\end{array}$ & $\begin{array}{l}0,259 \\
0,376 \\
0,441\end{array}$ & $\begin{array}{l}0,260 \\
0,392 \\
0,451\end{array}$ & $\begin{array}{l}0,300 \\
0,397 \\
0,445\end{array}$ \\
\hline leguminosas e oleaginosas & $\begin{array}{l}1 \\
? \\
3\end{array}$ & $\begin{array}{l}0,470 \\
0,7 ? 1 \\
0,796\end{array}$ & $\begin{array}{l}0,515 \\
0,751 \\
0.807\end{array}$ & $\begin{array}{l}0,557 \\
0,755 \\
0,803\end{array}$ & $\begin{array}{l}0,557 \\
0.778 \\
0,816\end{array}$ & $\begin{array}{l}0,621 \\
0,785 \\
0,808\end{array}$ \\
\hline Legumes e verduras & $\begin{array}{l}1 \\
2 \\
3\end{array}$ & $\begin{array}{l}0,283 \\
0,546 \\
0,898\end{array}$ & $\begin{array}{l}0,334 \\
0,589 \\
0,920\end{array}$ & $\begin{array}{l}0,383 \\
0,595 \\
0,911\end{array}$ & $\begin{array}{l}0,384 \\
0,628 \\
0,938\end{array}$ & $\begin{array}{l}0,466 \\
0,638 \\
0,922\end{array}$ \\
\hline Erutas & $\begin{array}{l}1 \\
2 \\
3\end{array}$ & $\begin{array}{l}0,050 \\
0,194 \\
0,492\end{array}$ & $\begin{array}{l}0,069 \\
0,226 \\
0,516\end{array}$ & $\begin{array}{l}0,090 \\
0,230 \\
0,506\end{array}$ & $\begin{array}{l}0,091 \\
0,257 \\
0,538\end{array}$ & $\begin{array}{l}0,133 \\
0,265 \\
0,520\end{array}$ \\
\hline Carnes e pescados & $\begin{array}{l}1 \\
2 \\
3\end{array}$ & $\begin{array}{l}0,638 \\
1,804 \\
3,364\end{array}$ & $\begin{array}{l}0,806 \\
2,009 \\
3,482\end{array}$ & $\begin{array}{l}0,978 \\
2,037 \\
3,433\end{array}$ & $\begin{array}{l}0,983 \\
2,201 \\
3,584\end{array}$ & $\begin{array}{l}1,293 \\
2,252 \\
3,497\end{array}$ \\
\hline Oros, leite e queifos & $\begin{array}{l}1 \\
2 \\
3\end{array}$ & $\begin{array}{l}0,322 \\
0,638 \\
1,105\end{array}$ & $\begin{array}{l}0,397 \\
0,703 \\
1,140\end{array}$ & $\begin{array}{l}0,473 \\
0,712 \\
1,126\end{array}$ & $\begin{array}{l}0,475 \\
0,763 \\
1,170\end{array}$ & $\begin{array}{l}0,608 \\
0,779 \\
1,144\end{array}$ \\
\hline Oleos e gorduras & $\begin{array}{l}1 \\
2 \\
3\end{array}$ & $\begin{array}{l}0,469 \\
0,877 \\
1,172\end{array}$ & $\begin{array}{l}0,534 \\
0,931 \\
1,194\end{array}$ & $\begin{array}{l}0,595 \\
0,938 \\
1,185\end{array}$ & $\begin{array}{l}0,596 \\
0,978 \\
1,213\end{array}$ & $\begin{array}{l}0,695 \\
0,991 \\
1,197\end{array}$ \\
\hline Bebidas e diversos & $\begin{array}{l}1 \\
2 \\
3\end{array}$ & $\begin{array}{l}0,356 \\
0,618 \\
0,907\end{array}$ & $\begin{array}{l}0,402 \\
0,653 \\
0,923\end{array}$ & $\begin{array}{l}0,445 \\
0,657 \\
0,916\end{array}$ & $\begin{array}{l}0,445 \\
0,684 \\
0,936\end{array}$ & $\begin{array}{l}0,514 \\
0,692 \\
0,925\end{array}$ \\
\hline Alimentaçào fora do domicílio & $\begin{array}{l}1 \\
2 \\
3\end{array}$ & $\begin{array}{l}0,151 \\
0,209 \\
0,473\end{array}$ & $\begin{array}{l}0,161 \\
0,215 \\
0,478\end{array}$ & $\begin{array}{l}0,170 \\
0,216 \\
0,476\end{array}$ & $\begin{array}{l}0,170 \\
0,220 \\
0,482\end{array}$ & $\begin{array}{l}0,184 \\
0,222 \\
0,478\end{array}$ \\
\hline
\end{tabular}


Na alternativa drästica, verifica-se para o ültimo estrato um consumo 1,82 vezes superior em "Frutas", 1,51 vezes em "Ovos-leite e queijos"e 2,40 vezes em "Alimentação fora do domicilio".

O primeiro estrato ultrapassa o ültimo somente no consumo de "Cereais e derivados" (1,03 vezes mais) e "Leguminosas e Oleaginosas" $(1,15$ vezes mais $)$.

A mesma comparação de gastos em alimentação realizada a nivel das äreas mostra que:

Para 1984, com redistribuição média de renda, as famílias da área metropolitana do estrato de renda inferior em nenhum grupo de ali mentos superam os gastos do estrato superior, salvo no item "Leguminosas e Oleaginosas".

O terceiro estrato ainda gasta em relação ao primeiro: 1,86 vezes mais em "Frutas", 1,51 vezes mais em "Legumes e Verduras" e 2,18 vezes mais em "Alimentação fora do domicilio", citando apenas os casos mais agudos.

Em relação à ärea urbana não-metropolitana, verifica-se que o dispêndio com alimentos no estrato superior, que no ano-base se apresentava 2,21 vezes o do estrato inferior, em 1984 é apenas 1,62 vezes maior.

A ârea rural foi a que apresentou maior impacto da politica de redistribuição médía de renda sobre o dispêndio familiar.

Em média, o dispêndio com alimentos da classe inferior da população rural, que em 1974 era de 4,209, em 1984 passa a 6,614; enquanto 
a classe superior que apresentava um dispêndio familiar de 12,710 atinge somente 13,025 .

Citando apenas os casos mais agudos, observa-se para os grupos de alimentos as seguintes variações:

Em 1974, a ültima classe de despesa apresentava um consumo em relação à primeira classe: 9,84 vezes superior em "Trutas", 5,27 vezes em "Carnes e Pescados", 3,43 vezes em "Ovos-Leite e Quei jos".

Jā em 1984, na alternativa de redistribuição média, tem-se para o terceiro estrato um consumo apenas 3,91 vezes superior em "Frutas", 2,70 vezes em "Carnes e Pescados" e 1,88 vezes em "Ovos-Leite e Queijos".

Verifica-se, portanto, que mudanças na distribuição de ren da refletem, naturalmente, na estrutura de demanda de alimentos, sendo que quando essa mudança favorece as classes de renda mais baixas ocorre um acréscimo significativo no consumo de alimentos dessa parcela da popul ação.

Especificamente em relação à "Alimentação fora do domicílio", ressalta-se que a despesa com este item começa a se destacar entre os constituintes de maior peso no orçamento doméstico da população de São Paulo, principalmente nas classes mais altas de renda, assumindo relativa importância na determinação do estado nutricional desses indivíduos. Deste modo, è de grande utilidade que pesquisas de âmbito nutricional se preocupen em realizar levantamentos do conteüdo dessas refeições para não se subestimar o estado nutricional das mesmas. 


\subsubsection{Projeções do dispêndio total}

Através das tabelas $32,33,34$ e 35 observa-se o efeito da redistribuição de renda sobre o nível de demanda total.

Nota-se que, para 1984, dadas as taxas de redistribuição de renda, è possível aumentar substancialmente a demanda de alimentos, especialmente dos produtos com elasticidade-renda elevada.

Tomando-se por base o dispêndio total de 1974, verifica-se em 1984, no Estado de São Paulo, um aumento na demanda de alimentos da or dem de $55 \%$ se não há redistribuição e de $72 \%$ no caso de uma redistribuição drāstica.

0 crescimento da demanda se deve, em grande parte, ao cres cimento da população.

0 efeito da redistribuição de renda fica mais claro quando se considera o crescimento do dispêndio médio por famillia. No Estado de São Paulo, entre 1974 e 1984, o dispêndio com alimentos por família cresce $11 \%$ quando não há redistribuição e cresce $22 \%$ no caso da redistribuição de renda drästica.

Para "Carnes e Pescados" tem-se um aumento na demanda total de $61 \%$ se não há redistribuição e de $85 \%$ na alternativa drāstica. Os dispêndios por família crescem, respectivamente, $15 \%$ e $32 \%$.

A anālise ao nível das áreas mostra que os maiores acréscimos na demanda total ocorrem na área metropolitana, devido ao seu maior crescimento populacional (5,5\%). Nesta, entre 1974 e 1984, registra-se 
um aumento na demanda total de alimentos de aproximadamente $90 \%$ no

de redistribuição nula e de $106 \%$ na redistribuição média ou $11 \%$ e $20 \%$, res pectivamente, nos dispêndios por familia.

A variação mais acentuada ocorre para o item "Frutas", apresentando um acréscimo de $98 \%$ na alternativa de redistribuição nula e $119 \%$ na alternativa de redistribuição média. Os dispêndios por familia crescem, respectivamente, $17 \%$ e $31 \%$.

Por sua vez, a ärea rural apresenta um. acréscimo na demanda total de alimentos de apenas $5 \%$ e $11 \%$ na alternativa de redistribuição nula e mëdia, respectivamente. Esses baixos valores se devem ao decréscimo populacional esperado para essa ärea. Os dispêndios com alimentação por familia crescem, respectivamente, $15 \%$ e $21 \%$.

Note-se, porém, que a projeção de demanda para o estado como um todo não corresponde a soma das projeções por āreas, isto é, a propriedade aditiva não se verifica. Observe-se que para o item "Carnes e Pescados" o dispêndio total em 1984, na hipōtese de redistribuição mêdia de renda, apresenta um valor de 15.567,6 para o estado, enquanto a so ma dos dispêndios relativos às três àreas é igual a 17.161,8.

Ressalte-se que a elasticidade-renda média do estado difere das elasticidades-renda das äreas quando isoladas, afetando o resultado das projeções. Isto mostra a importância do uso de projeções desagregadas por áreas quando o objetivo ë obter previsões mais realistas da demanda por alimentos. 


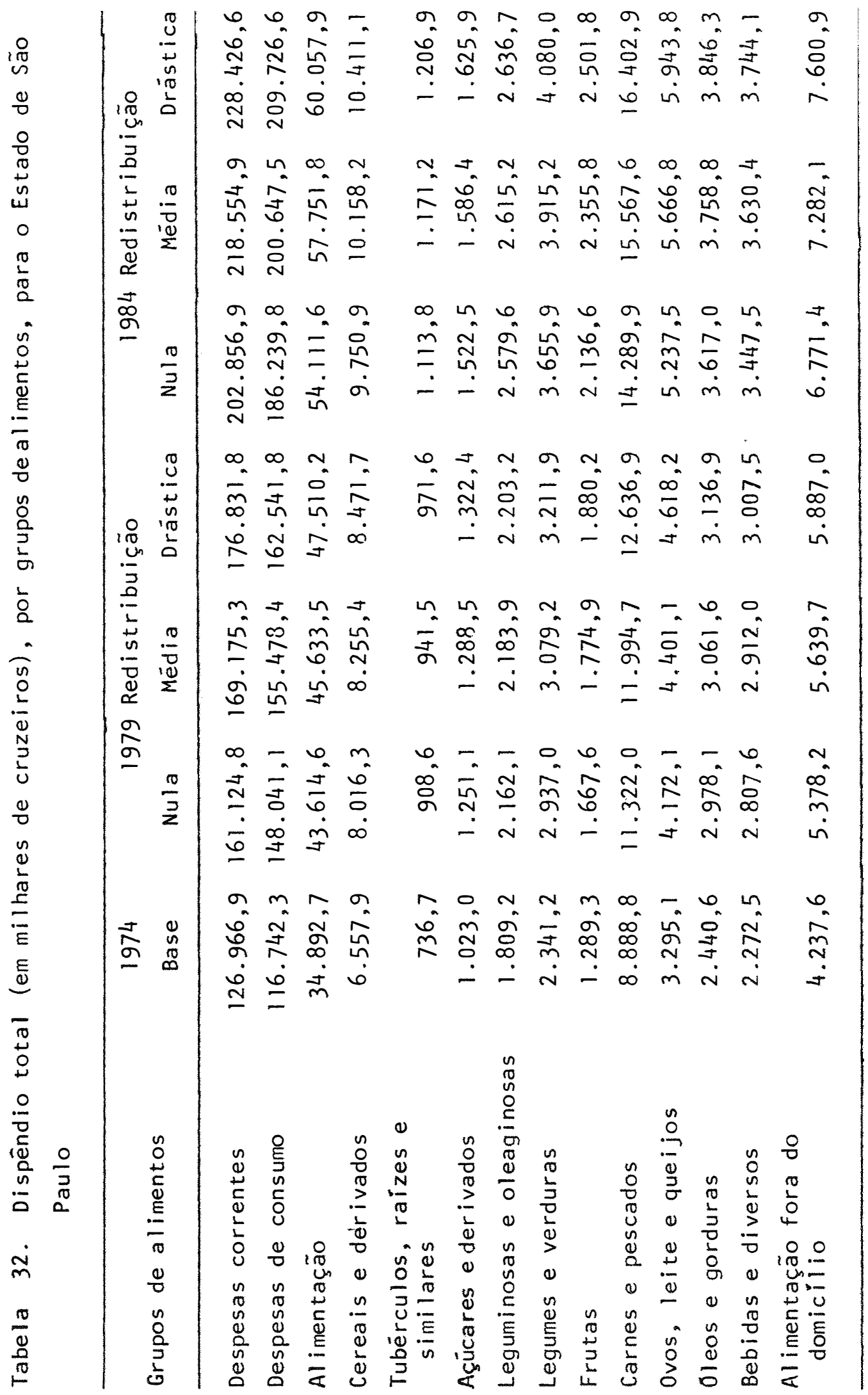




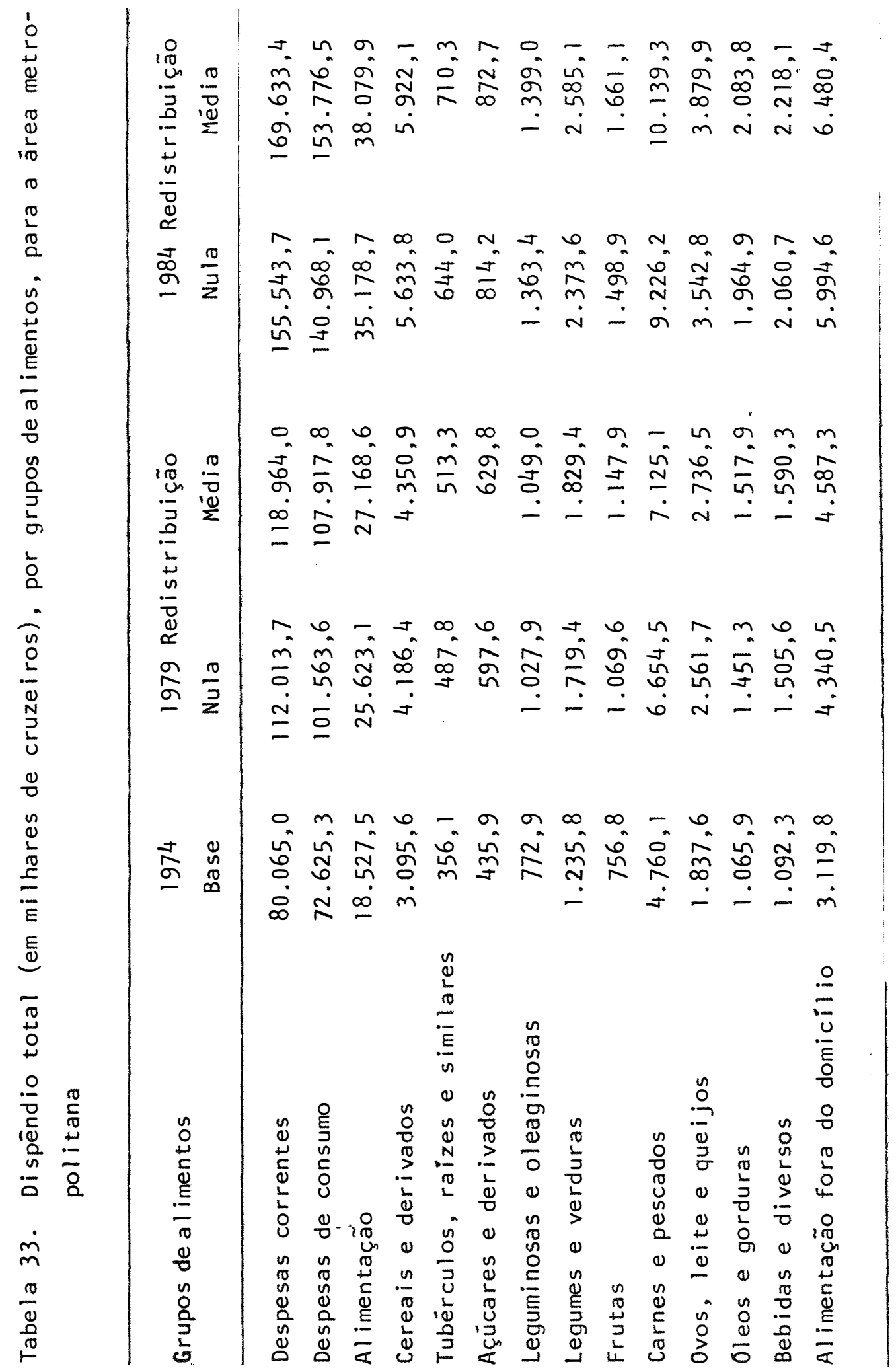




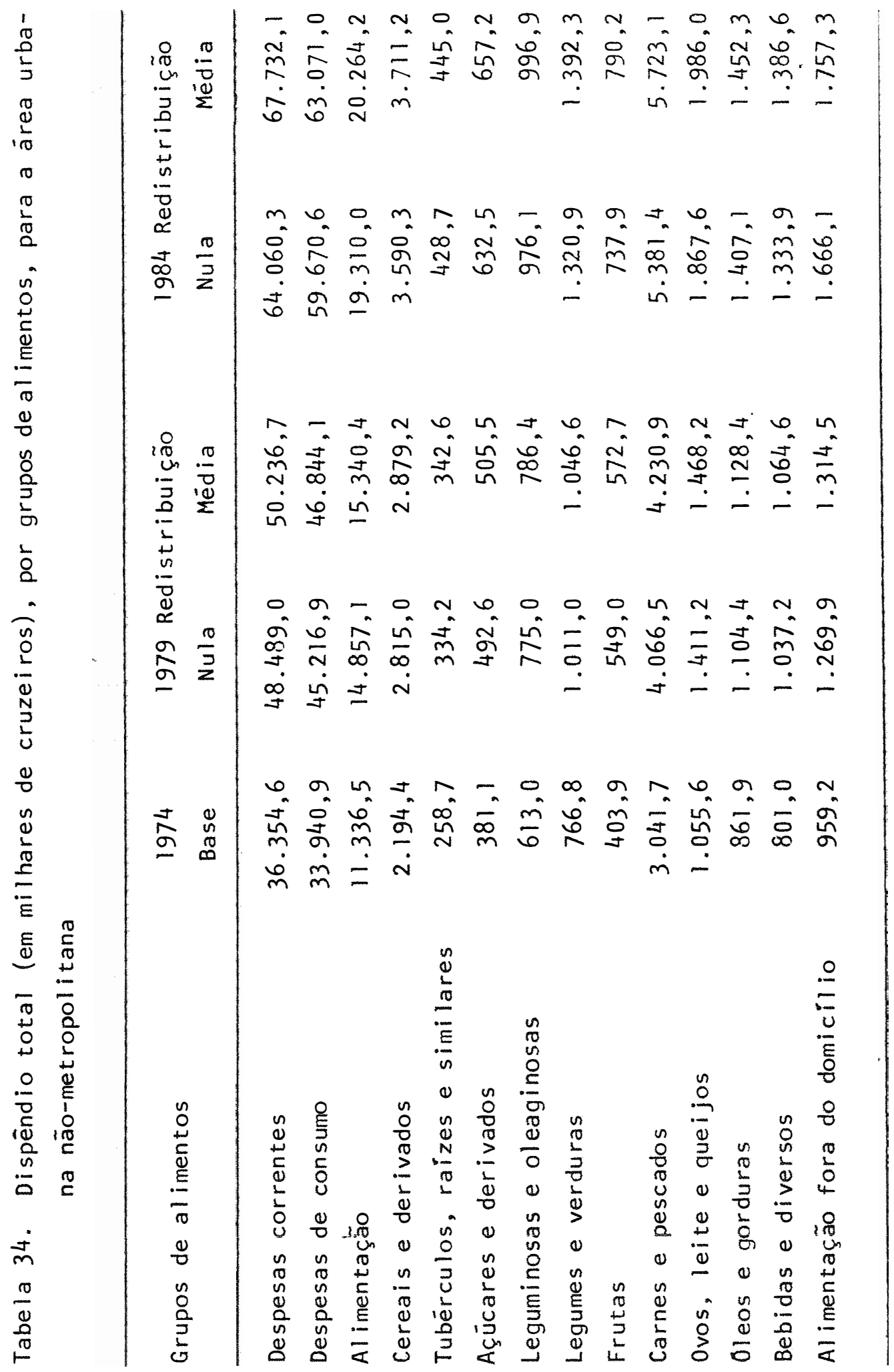




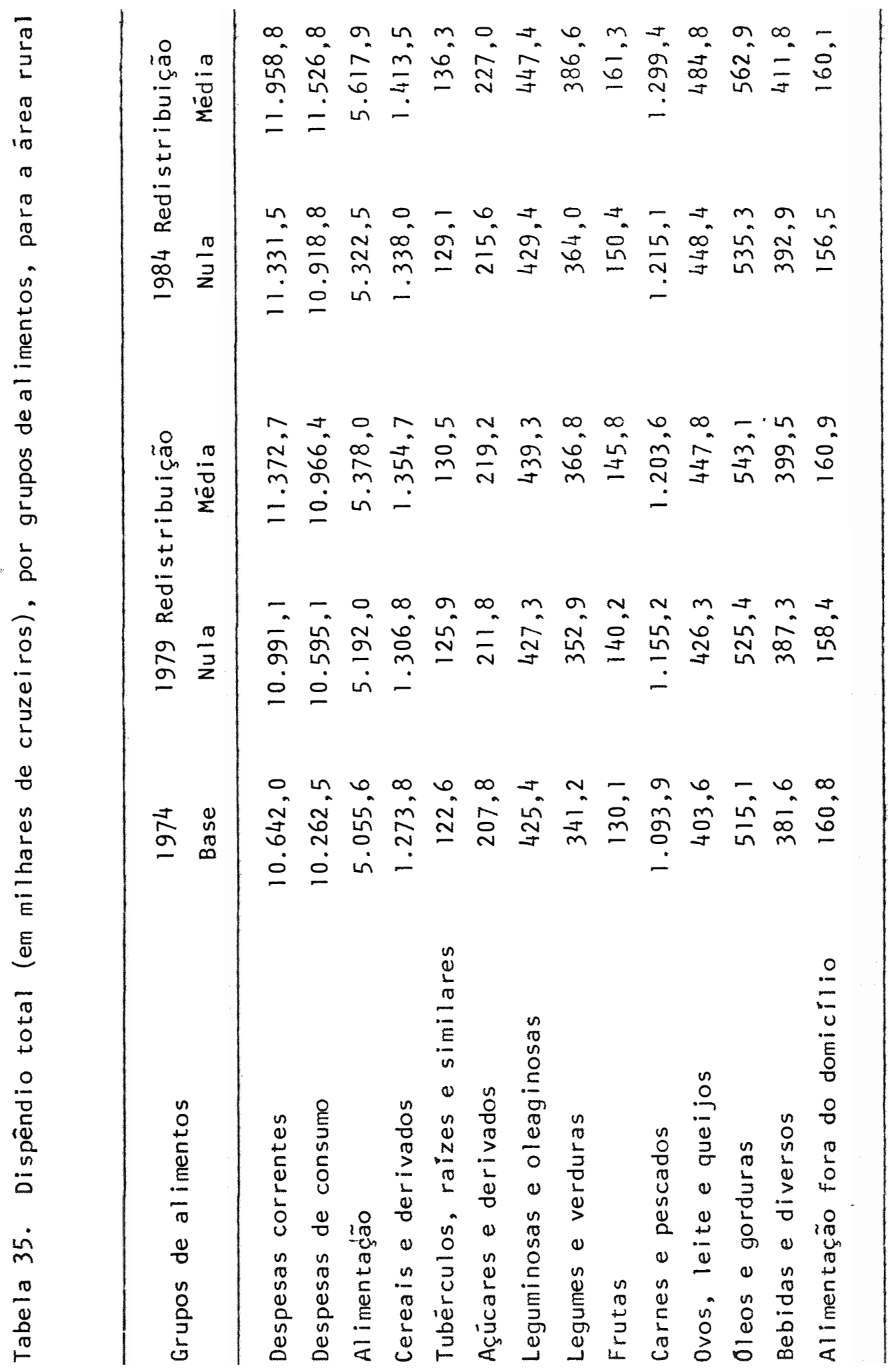




\section{CONCLUSOES}

A anālise dos resultados obtidos permite elaborar as conclusões que seguem.

A renda mostra-se assimetricamente distribuida entre a população do Estado de São Paulo, com os $50 \%$ mais pobres apresentando uma participação percentual na despesa global ou renda menor do que a apresentada pelos $5 \%$ mais ricos da população. Ao se proceder o detalhamento dos dados ao nível das àreas, observa-se um grau de concentração de renda ma is elevado para a àrea metropolitana, com um índice de Gini igual a 0,536 , en quanto o da área urbana não-metropolitana e o da rural são, respectivamente, 0,471 e 0,470 .

Os resultados encontrados mostraram ser este padrão de dis tribuição de renda um importante fator que contribui para a diferenciação na estrutura de consumo de alimentos entre os estratos de renda. Enquanto no estrato de renda inferior os alimentos de natureza calörica têm uma grande participação na "cesta" de alimentos, no estrato superior a estrutura de consumo apresenta-se mais diversificada, comuma maior participação 
de alimentos mais ricos nutricionalmente.

Apōs a redistribuição de renda simulada, observam-se para 1984 mudanças sensiveis na dieta da população de renda inferior, com acentuado aumento do peso relativo dos alimentos de maior valor protéico e nutricional.

No caso do grupo "Carnes e Pescados" (Estado de São Paulo), por exemplo, nota-se que na alternativa de redistribuição drästica a participação do consumo do 1 : estrato apresenta um grande acréscimo, passando de $27,3 \%$ para $41,2 \%$, enquanto a participação do consumo do 3 ? estrato declina de $39,9 \%$ para $30,2 \%$.

Em termos de gastos com os grupos de alimentos observa-se que o estrato inferior e o superior mantêm praticamente a mesma ordem na escolha dos principais grupos de produtos, embora o dispêndio realizado nestes itens pela população de baixa renda seja menor. Tal fato sugere ser o baixo poder aquisitivo o fator limitante do consumo dessa população.

Quando se analisou a influência da redistribuição de renda sobre os gastos al imentares, verificou-se que alterações no padrão de distribuiçāo de renda se refletem na estrutura de consumo de al imentos, sendo que uma distribuição de renda menos desigual ocasiona a melhoria na qualidade da alimentação do estrato inferior. Observa-se que, no Estado de São Pauto, o dispêndio alimentar do estrato superior $\left(E_{3}\right)$, que era 2,24 vezes o do estrato inferior $\left(E_{1}\right)$, com a alternativa de redistribuição drästica passa a ser apenas 1,37 vezes maior. O indice de Gini da distribuição do consumo decresce, neste período, de 0,18 em 1974 para 0,07 em 1984 . 
De um modo geral, os maiores aumentos no consumo

ocorrem para os grupos de alimentos que apresentam elasticidade-renda elevada. Como exemplo, pode-se citar as "Frutas", cujo dispêndio do estrato superior, que no ano-base se apresentava 4,78 vezes o do estrato inferior, em 1984, com a redistribuição drāstica, é apenas 1,82 vezes maior. 0 indice de Gini da distribuição do consumo que era igual a 0,34 em 1974 passa a 0,13 em 1984.

A anālise ao nível das àreas mostra que os maiores acrëscimos no consumo ocorrem para a população de renda inferior da área metropolitana e da rural, regiões que apresentavam um quadro alimentar nitidamente pior para essá parcela da população. Entre estas, a área rural foi a que apresentou maior impacto da politica de redistribuição de renda simulada. Note-se que, o dispêndio alimentar do lo estrato da população rural que no ano base era de 4,209 passa a 6,614 (57\%) em 1984; enquanto o 30 estrato, que apresentava um gasto alimentar de 12,710 , atinge somente $13,025(2,5 \%)$.

Assim, constata-se que polifticas de redistribuição de renda causam fortes impactos sobre os gastos al imentares da população de baixa renda, pois, após as taxas de redistribuição adotadas, embora continui a superioridade do dispêndio alimentar do terceiro estrato em relação ao primeiro, essas diferenças diminuem consideravelmente.

Em termos da demanda total, verifica-se que pode haver aumento substancial da demanda de alimentos devido a mudanças na distribuição de renda. Note-se que, no Estado de São Paulo, entre 1974 e 1984 , o dispêndio com alimentos por familia apresenta um acréscimo de $11 \%$ no caso 
de redistribuição nula e de $22 \%$ no caso de redistribuição drástica. Entre os grupos de alimentos destaca-se o item "Carnes e Pescados" cujo dispêndio por familia cresce, respectivamente, $15 \%$ e $32 \%$.

Ressalta-se, assim, a importância de se incluir este fator na estimação e elaboração de projeções de demanda, pois seu conhecimento pode ajudar a prever possíveis desequilibrios entre produção e consumo, os quais acarretariam sensiveis elevações nos preços dos alimentos.

Os resultados deste trabalho mostram de maneira clara que a renda e sua distribuição são fatores limitantes do consumo, desempenhando um papel relevante na composição da "cesta" de alimentos da população.

Supondo crescimento equilibrado entre produção e consumo, a melhora na qualidade da dieta da população está diretamente relacionada com a mudança na estrutura de distribuição de renda. Assim, impactos positivos na estrutura alimentar da população de baixa renda podem ser conseguidos através de políticas econômicas, que visem alterar a renda real dos consumidores e/ou os preços dos bens.

Em relação aos coeficientes de elasticidade, os resultados da pesquisa confirmaram a necessidade do uso de elasticidades diferentes para os vários estratos de renda em cälculos de projeções de demanda, quan do o intuito é obter projeções mais realistas.

Ressaltou-se, também, a não conveniência de se estimar o crescimento da demanda e efetuar projeções, representativas do estado, ten do em vista que a elasticidade-renda média do estado difere das elasticidades-renda das äreas isoladas. 
Na presente pesquisa considerou-se somente a estrutura de consumo al imentar, não levando em conta os outros itens que compõem a estrutura do orçamento doméstico, os quais poderiam ser analisados em novas pesqui sas nesta ärea.

Este estudo, tambēm, restringiu-se apenas à anälise da relação entre a estrutura de gastos com alimentos frente a diferentes padrões de distribuição de renda. Não constituiu objetivo do trabalho a ave riguação do nivel de adequação nutricional. Poder-se-ia, em futuras pesquisas, calcular a magnitude da redistribuição de renda necessäria para eliminar os eventuais déficits nutricionais, o que sem düvida é de grande importância em um país como o Brasil em que uma parte significativa da população sofre de desnutrição. 
6. LITERATURA CITADA

ACKLEY, G., 1969. Teoria Macroeconômica. São Paulo, Livraria Pioneira Editora. Vol. 11, $630 \mathrm{p}$.

ARAUjO, A.L.M.de, 1970. Relações Funcionais entre Renda, Educação e Con sumo de Alimentos, na Cidade de Vitöria, ES, Viçosa, Universidade Federal de Viçosa, 82 p. (Tese de Mestrado).

ATEAGA, R.M. e F. MARTINEZ, 1973. Efecto de la Redistribución de los Ingressos en la Demanda por Alimentos: Chile 1970-1980. Chile, Universidade Católica de Chile, Departamento de Economia Agraria. 123 p. (Sërie A: Trabajos de Investigación, 5).

BRASIL. Ministērio da Agricultura. Departamento Econômico, 1967. Relações Funcionais entre Renda e Consumo de Alimentos pela Populaçäo. Urbana do Estado da Guanabara. Rio de Janeiro, $45 \mathrm{p}$. 
BRASIL. Fundação Instituto Brasileiro de Geografia e Estatística, 1978. Estudo Nacional da Despesa Familiar (ENDEF). Despesas das Familias. Dados preliminares - Reg. 11 - Estado de São Paulo. Rio de Janeiro, $85 \mathrm{p}$.

BRESSER PEREIRA, L.C., 1972. Desenvolvimento e Crise no Brasil. 3를ção. São Paulo, Editora Brasiliense, $234 \mathrm{p}$.

CAMPINO, A.C.C., 1979. Situação Nutricional no Brasil: Uma Descrição e Criticas as Estimativas do FIBGE. In: VII Encontro Nacional de Economia da Associação Nacional de Centros de Pós-Graduação em Economia. Porto Alegre, Editora Meridional, p.739-765.

CASTRO, A.B.de, 1972. Aspectos da Interdependência Econömica entre a Estrutura de Consumo e a Comercialização Agrícola. Piracicaba, ESALU/ USP, $100 \mathrm{p}$. (Tese de Doutoramento).

CEPAL, 1970. La Distribuciön del Ingreso en Brasil. Escritörio. CEPALILPES no Brasil, Rio de Janeiro. (Mimeografado).

CODEPLAN, Brasilia, 1970. A Renda e a Demanda de Produtos Alimenticios. Diagnóstico do Abastecimento de Produtos Alimentícios do Distrito Federal, Tomo 1, $215 \mathrm{p}$.

DIAS, A.B., 1976. Market Demand and Income Distribution. Recife. $147 \mathrm{p}$. (Tese de Doutoramento). 
FUNDAÇÃO GETOLIO VARGAS, 1979. Conjuntura Econômica. Rio de Janeiro, Vol. $33(12)$.

HOFFMANN, R. e S.VIEIRA, 1977. Anälise de Regressão. São Paulo, Editorá Huticec. 339 p.

HOFFMANN, R., 1979. Estimação da Desiqua'ldade Dentro de Estratos no Cálculo do Tndice de Gini e da Redundância. Pesquisa e Planejamento. Econômico. Rio de Janeiro, $\underline{9}(3): 719-738$.

KUZNETS, S., 1955. Economic Growth and Income Inequality. The American Economic Review. Wisconsin, XLV $(1): 1-28$.

KUZNETS, S., 1963. Quantitative Aspects of the Economic growth of Nations. Economic Development and Cultural Change. Wisconsin, $X_{1}(2): 1-80$.

KUZNETS, S., 1966. Teoria do Crescimento Econômico Moderno. Rio de Janeiro, Zahar Editores. 279 p.

MELLOR, J.W., 1967. O Planejamento do Desenvolvimento Agrícola. Rio de Janeiro, Edições 0 Cruzeiro. $413 \mathrm{p}$.

ORGANIZACION DE LAS NACIONES UNIDAS PARA LA AGRICULTURA Y LA ALIMENTACION, Roma, 1971. Proyecciones para Productos Agricolas 1970-1980. Vol. I, $358 \mathrm{p}$. 
ORGANIZACIÓN DE LAS NACIONES UNIDAS PARA LA AGRICULTURA Y LA ALIMENTACION, Roma, 1972. Efectos Sobre la Demanda de los Cambios en la Distribución de la Renta. Boletin Mensual de Economia y Estadistica Agricolas, Vol. $21, n ? 3$.

PARETO, V., 1949. Corso di Economia Politica. Itälia, Giulio Einaudi Editore.

PEREZ, M.C.R.C., 1973. Contribuição ao Estudo da Elasticidades-Renda do Consumo de Alimentos. Piracicaba, ESALQ/USP, $94 \mathrm{p}$. (Tese de Mestrado) .

PINSTRUP, A. e E.CAICEDO, 1978. The Potential Impact of Changes in Income Distribution on Food Demand and Human Nutrition. American. Journal of Agricultural Economics. Columbia, 60(3):402-415.

SÃO PAULO. Secretaria de Economia e Planejamento, 1978. Projeções da População para o Estado de São Paulo 1970-1990. 133 p.

SCHUH, G.E. e E.R.ALVES, 1970. O Desenvolvimento da Agricultura no Brasil. Rio de Janeiro, APEC Editora S.A. 369 p.

SILVA, W., 1970. Diagnöstico da Situação Alimentar no Brasil. Produtos e Nutrição. $4: 15-41$. 


\section{APENDICE}

Taxa de crescimento da renda familiar do primeiro estrato. Definem-se as variāveis:

$P_{o j}$, com $j=1,2,3$, representa a população do j-ēsimo grande estrato no ano-base de 1974.

$Y_{\circ j}, \operatorname{com} j=1,2,3$, indica a renda familiar no j-ésimo grande estrato no ano-base de 1974.

$V_{o j}, \operatorname{com} j=1,2,3$, representa a renda total do j-ésimo estrato no anobase de 1974.

Substituindo o indice 0 (zero) por $\underline{t}$, esses simbolos passam a representar os valores dessas variäveis no t-ésimo ano após o anobase considerado.

Seja p a taxa de crescimento da população. Então,

$$
P_{t j}=P_{0 j}(1+p)^{t} \quad(j=1,2,3)
$$

Seja $r_{j}$ a taxa de crescimento da renda familiar no j-ésimo grande estrato. Então,

$$
y_{t j}=y_{0 j}\left(1+r_{j}\right)^{t} \quad(j=1,2,3)
$$

Se Yo representa a renda mëdia por familia em toda a população, no ano-base, e $y_{t}$ representa essa renda média $\underline{t}$ anos após, temos

$$
Y_{t}=Y_{0}(1+r)^{t}
$$


onde $r$ é a taxa de crescimento da renda média por família de toda a população.

Tem-se que

$$
v_{t j}=P_{t j} Y_{t j} \quad(j=1,2,3)
$$

Então a renda total da população no ano $\underline{t}$ è dada por

$$
\sum_{j=1}^{3} P_{t j} Y_{t j}
$$

Uma vez que o número de familias no ano $\underline{t}$ é igual a $\sum_{j} P_{t j}$, a renda média por familia é

$$
Y_{t}=\frac{\sum_{j=1}^{3} P_{t j} Y_{t j}}{\sum_{j=1}^{3} P_{t j}}
$$

Lembrando (1) e (2), segue-se que

$$
Y_{t}=\frac{\sum_{j=1}^{3} P_{0 j}(1+p)^{t} Y_{0 j}\left(1+r_{j}\right)^{t}}{\sum_{j=1}^{3} P_{0 j}(1+p)^{t}}
$$

Simplificando e igualando com (3), obtēm-se

$$
Y_{0}(1+r)^{t} \sum_{j=1}^{3} P_{0 j}=\sum_{j=1}^{3} P_{O j} Y_{0 j}\left(1+r_{j}\right)^{t}
$$

Seja $V_{0}$ a renda total da população no ano-base. Então, 


$$
V_{0}=Y_{0} \sum_{j=1}^{3} P_{0 j}
$$

Substituindo esse resultado em (4) e notando que $P_{o j} Y_{o j}=V_{o j}$, obtēm-se

$$
v_{0}(1+r)^{t}=\sum_{j=1}^{3} V_{o j}\left(1+r_{j}\right)^{t}
$$

No caso particular em que $t=1$, tem-se

$$
v_{0}(1+r)=\sum_{j=1}^{3} v_{0 j}\left(1+r_{j}\right)
$$

Desenvolvendo e notando que $v_{0}=\sum_{j=1}^{3} v_{0 j}$, conclui-se que

$$
v_{0} r=\sum_{j=1}^{3} v_{0 j} j_{j}
$$

Segue-se que

$$
r_{1}=\frac{1}{v_{o_{1}}}\left(v_{0} r-v_{o_{2}} r_{2}-v_{o_{3}} r_{3}\right)
$$

Esta expressão mostra como, fixados os valores de $r, r_{2} e$ $r_{3}$, pode-se obter o valor de $r_{1}$, isto é, a taxa de crescimento da renda familiar no primeiro estrato.

Generalizando, para a taxa de crescimento da renda familiar $\left(r_{1}\right)$ entre os anos $t-1$ e $t$, temos

$$
r_{1}=\frac{1}{v_{t-1,1}}\left(v_{t-1} r-v_{t-1,2} r_{2}-v_{t-1,3} r_{3}\right)
$$

